Historic, archived document

Do not assume content reflects current scientific knowledge, policies, or practices. 



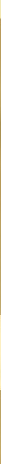

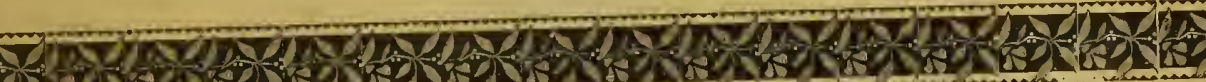

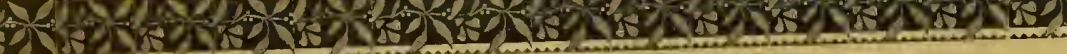

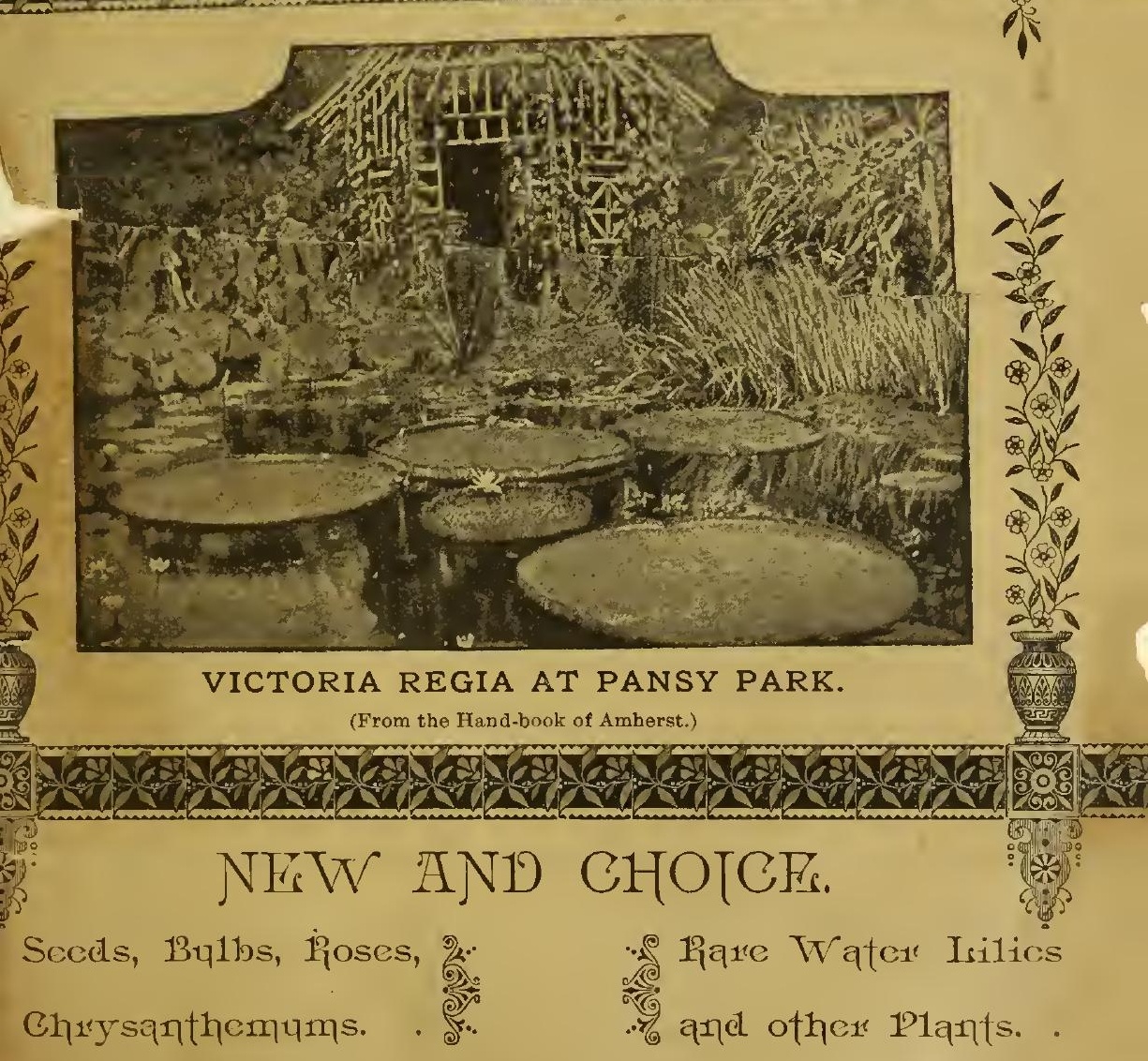

L. W. GOODELL, : Pansy Park, Dwight, Mass. 
take great pleasure in distributing my Catalog of Seeds and Plants for 1893. My customers, many of whom have used my goods for years, will need no words of praise as to their quality, but as this Catalog will fall into the hands of many who have never dealt with me I desire to say that I have made a specialty of growing flower seeds for the past sixteen years. From my earliest recollection I have had a taste for gardening, and long before I ever thought of engaging in the business of seed-growlng I had grown and experimented with neariy every variety of flower and vegetable that could be grown in this cllmate, for pleasure, and it is to this that I attribute much of my success In business. Beginning with a capital of twenty-five dollars and less than two hundred customers the first year I had several thousands the second, and it has gone on increasing rapidly until now "Goodell's seeds" are not only planted in thousands of gardens in all parts of America, but orders are often received from Europe, the East and West Indias, Japan, Australia, New Zealand and many other foreign lands. Competition in the seed-trade has been very keen for a number of years and my extensive trade, won in competition with old established firms and the multitude of new ones which have since sprung up is the result of fair and lfberal dealing and the determination which I have always strictiy adhered to not to send out any but first-class seeds.

Most of the flower seeds sold in this country are imported from Europe, and until within a few years it was supposed they could not be grown in America, lout it has been found that with proper care and skill, seeds of many of our most popular flowers can be produced here of much better quality than the European seeds, the chief difficulty being the cost of production. I have grown many acres the seeds from which cost me two or three times as much as the same quantity could have been imported for. The amount of time, skill and care necessary to produce seeds of the hlghest quality cannot be understood or appreeiated by those not acquainted with the details of the business. I have succeeded in greatly improving some of the most popular varieties, which haje been awarded many First Prizes at the shows of the Mass. Horticultural Society at Boston and at other fairs where I have exhibited them. Varieties that do not perfect their seeds in this climate and those that experience has show $\mathrm{n}$ are better for being grown elsewhere, I import from the most reliable growers of England, Germany and France. In December of each year I make careful tests of the germinating qualities of every variety I offer, and all that do not germiuate properly are at once burned or thrown awa,y, and it ls almost impossible that any seeds I send out will fail to grow from any fault in the seeds.

$\boldsymbol{I}$ send Seeds, Bulbs aud Plants by mail, postage paid, to any part of this country or Canada and guarantee the safe delivery at your post office, of all goods ordered, in good condition. We car also send large packages by mail to Mexico, Sandwich Islands, Jamaica, the Danish West Indi lombia, Costa Rica, and San Salvador. To other foreign countries only small packages of 8 or each can be sent.

Ironey may bespent at my rist if sent $\mathrm{h}=n$ or Registered Letter ava

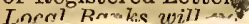
in by rostal Noto.

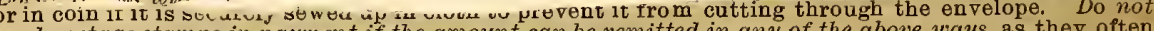
send postage stamps in payment if the amount can be remitted in any of the above ways, as they often come in a bad and worthless condition from dampness or other causes. A sufficient amount to pay for all goods ordered should be enclosed as it is my invariable rule to send goods only to the value of the remittance.

In making up your order be sure that NAME, POST-OFFICE, COUNTY and STATE are plainly wrltten on every order. Every day during the busy season I receive letters with one and sometimes all of these important items wanting; and then all I can do is to wait until I receive scolding letters, and am perhaps called hard names, when the fault is entirely with the customer.

We take the greatest care in filling orders, yet it is impossible, in the hurry of the busy season, to avoid occasional mistakes, and where errors occur, please do not think that I design to cheat jou, but notify meat once, stating just what the error is, and I will make prompt and satisfactory correctlon.

Keep a copy of your order, so that when the package is opened you can see if everything is correct, for customers sometimes forget what they ordered and complain without cause. Do not order varieties not offered in this Catalog.

Seeds and Plants when ordered together, if to go by mail, will be sent in one package, or separate as may be most convenient, but those who wish to have plants shipped at a later date will please so state and we will ship at any time desired.

Please make out PLANT orders entirely separate from $\boldsymbol{S E E D}$ orders and not mix the names of seeds and plants together; and as far as possible write the names as they come in the Catalog, beginning on the first pages.

The great majority of order's are sure to reach me safely, but it occasionally happens that a letter is lost or stolen. After waiting a reasonable length of time, if the seeds ordered do not arrive, then write again, always sending a duplicate order, and give the date on which the ori inal was sent, the wount of money enclosed and in what form. This will enable us to investigate, and fill the duplicate promptly. Enquiries cannot receive attention unless they contain duplicats, dc., as above.

Larly Urders. The seed trade of a whole year is crowded into a fow months, which makes a great rush of business, and it will be a great accommodation to me if all who can conveniently do so will send their orders as early as possible. The seeds will then be on hand when wanted for sowing, and customers will be sure of getting just what is ordered, for stocks of some of the most desirahle va. rleties often become exhausted late in the season.

Address all orders,

$$
\text { L. W. GOODELL, }
$$

Pansy Park, Dwight, Mass. GE- Have all Money Orders made payable at AMHERST, Mass.

\section{Collection of Aquatic Plants.}

For only $\$ 1.00$ we will send 6 Aquatic Plants as follows, (see pages $31-32$ for description): Eich hornia crassipes major, (Water. Hyacinth;) Timnocharis Humboldti, (Water Poppy:) Azolla Caroliniana, (Eloating Moss;) Myriophyllum proserpicoiales, (Parrot's Feather;) Limwanthemum Indicum, (East Indian Water Snowflake;) Sagittaria Joponica fl. pl., (Doubleflowered Arrow-head).

No changes can be made in any collection offered in this Catalog. 


\section{0-CENT COLLECTION OF SEEDS.}

\section{GOODELL'S DIAMOND COLLECTION,}

It has beeu $m v$ custom for many years to grow some of the cboicest and most popular varieties in extra large quantities and offer them iu collections for abou a quarter of tbe retail prices. I havesent out inillions of packets of these seeds, and have received mauj tbousands of lettels containiug expressions of the satisfaction thes have given to the purchasers; and I bave the pleasure of knowing that many who never cultivated a single flower before have been induced to begin their culture by my cheap collections. The past seasoll I have grown and put up the following 12 varieties especially for this collectiou and they will be sent to all who order it for only THIHTY CENTS, postpaid. Each packet contains from 100 to 500 seeds, and all are of the choicest quality in every respect. I am sometimes asked to make changes in the varieties, and while I am willing to accommodate customers in every way possible, fet in this I cannot do so, as I shall have them put up read for mailing before the busiest part of the season. It is on this very condition of no whange in connectiun with very lurge sules, that I chn offer them for such a small sum. Full descriptions will be found in tbe following pages.

1. Germun Pansies, all colors mixed. (About| $\boldsymbol{\gamma}$. China and Japan Pinks, all varietio one-half of the seeds in this packet are of the Dianoud strain.)

2. Double dsters, mixed; a large variety.

3. Helichrysum, (Everlastlng) mixed colors.

4. Fonletias, new varieties mixed.

5. New Jouble Poppy, Fairy Blush.

6. Plilox grendiflora, Pansy Park Prize struiu, all colors mixed. mixed.

8. Antirrhinum (Shaj)drayon) mixed colors.

9. Emperor Petunias, Dwarf varieties.

10. Calliopsis, all colors mixed

11. Double Portulaca, mixed colors

12. Chrysanthemum segetum yrandiflorum

\section{0-CENT COLLECTION OF SEEDS.}

Tbis contains all the varieties in the DIAMOND COLLECTION, as named above, and two more packets, - AFRICAN WATER LILIEs, Red, White and IBlue, mixed ; and the BRAZILIAN MUR IING GLORY (Ipomoen setosa).

\section{PREMIUMS TO CLUBS.}

These collections contain so many choice seeds and are sold at such a low prlce, that many cultiva. tors of flowers in every neighborhood would giadly order them if tbeir attention was only called to tbe matter. Many of my customers have raised clubs among tbeir frierds in past jears. Tbis is highly appreciated by me and I will reward liberally all who thus assist in extending my trade, as follows

For a club of two, remittiug 6 i cents, for the Diamond Collections, tbe club raiser may select flower seeds in packets from the Catalog amounting to 15 cents, for a premium. For a club of three, remitting 90 cents, for the Diamond Collections the club raiser may select seeds in packets amounting to 25 cents, for a premium. For a club of four, remitting $\$ 1.20$, for the Diamond Collections, the club raiser may select flower seeds in packets amounting to 40 cents, for a premium For each Diamond Collection ordered over four, select flower seeds in packets amounting to 10 cents, for a premium.

For a club of two, remitting $\$ 1.00$ for the Fifty-cent Collections, flower seeds in packets amnunting to 25 cents, may be selected for a premium. For a club of three, remitting $\$ 1.50$ for the Fifty-cent Collections, flower seeds in packets amounting to 45 cents, may be selected for a premium. For a club of four, remitting $\$ 3.00$ for the Fifty-cent Collections, flower seeds in packets amounting to 70 cents, may be selected for a premium. For eack Fifty-cent Collection ordered over four, flower seeds in packets amounting to 20 cents, may be selected for a premium. It should be understood that tbese premiums are offered only un collections ordered for others and not on collections ordered for a club raiser's own use. Any one who tries will be surprised to flad how easy it is to get up a club for these collections. Many have written tbat it is "no trouble at all," because the seeds are so good and cheap. All that is necessary in most cases is to call on your flower-loving friends, show them wbat a lot of cboice seeds they can get for a small sum and they will readily give you their orders. Many will want and order other seeds besides collections, and if you do not want tbe premium seeds for your own use, by selerting the seeds so ordered as premiums, you get a cash commission of about 30 per cent. on clubs of four and over. Here is a good chance for the boys and giris to get a supply of pocket money with a little work. Many of my young friends bave raised clubs in the past; any boy or girl who will try can easily raise one of four or more. The seeds will be sent to tha raiser of the club (which is much the best way wben convenient to distribute, as they usually go safer wben sent to one address), or, if not convenient for the raiser of the club to distribute them, to eacb member sfparately. Please send full nume and address of each member of the club, so that we can put them on our books and send tbem a Catalog next year. A copy of this year's Catalog will be sent for each memker of the club if wanted, and club-raisers will please state bow many are needed.

\section{Premiums on a General Selection of Seeds.}

The above premiums are offered on collections only, but those who raise clubs for a general selection of seeds in packets from the Catalog, or order for themselves alone, may select EXTRA SEEDS IN PACKETS to the value of THIRTY CTS. for each dollar sent. BUT IT MIUST BE UNDERSTOOD that tbis offer is made ONLY ON SEEDS IN PACKETS at the regular Catalog prices. SEEDS BY WEIGHT, OR MEASURE, OR IN COLLECTIONS, OR BULBS AND PLANTS, must not be reckoned at all towards tbese premiums, NOR CAN THE PREMIUMS BE PAID IN THEM, as it would bring the prlces below cost in some cases.

\section{Collection of Tropical Water Lilies.}

For only $\$ 1.50$ we will send the 4 following cboice Tropisal W ater Lilies, (See pages 4 and 30 for descrip. tina): Nympha Zanzibarensis azurea, (Blue Afican Water Lily: Nympheer Zanzibarensis rosea, (Red African Water Lily;) Nymphar ilentata, (White African Water Lily;) Nym. phrea scutifolire.

\section{Collection of Hardy Water Lilies.}

For only 33.50 we will send the following 4 choice Hardy Water Lilies, (See page 31 for description):

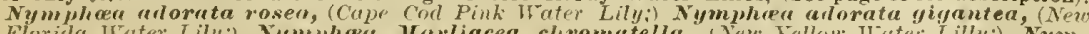

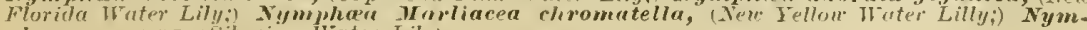
pha'e pygmara, (Siberian IFater Lily). 


\section{Novelties and Speciatties in Flower Seeds,}

\section{THE BRAZILIAN MORNING GLORY.}

\section{IPOMOEA SETOSA.}

To the genus Ipomcea we are indebted for some of the most magnificent of climbing plants. One of the most ornamental and finest of these is this new Brazilian Morning Glory introduced by me last year, but it is entirely distinct from the common Morning Glory. It is an annual and the most vigorons and rapid in growth of all vines, climbing 30 to 50 feet. The vines branch and climb in all directions, a single vine soon covering a large tree, arbor or building. Its leaves are like those of the Grape in form and of immense size, often a foot across in rich soil. The flowers, which open in the morning, are three inches or more across, of a beautiful rose color, and are boine in large clusters very treely from July to frost. Every part of the vine is thickly covered with short reddish hairs which, with its immense leaves and large clusters of curious seed capsules render it highly ornamental and give it quite a tropical appearance. For quickly covering a piazza or an arbor where a dense shade is required

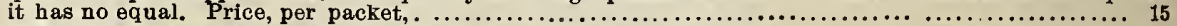

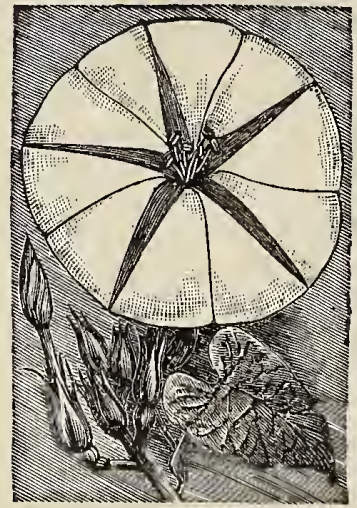

MOON FLOWER.

IPOMOSA grandiflora: (White-seeded or Giant Moon-flower : This is one of the grandest of climbing plants, and far superior in every way to the common Moon-flower, the Howers being much larger-5 to 6 inches across-of more substance and pure white. They open late in the afternoon and close in the morning. The vines make a rapid growth in rich soil, branching and climbing 25 or more feet, a single plant often having from a dozen to 50 of its magnificent flowers open at a time. This and the Brazilan Morning Glory make a very effective combination when planted together. Start the seeds early in the house,..... ............ 15

IPOMGA Leari, (Blue Moon-flower): 'One of the flnest species with flowers 4 inches across, of a rich satin blue shading to ruby

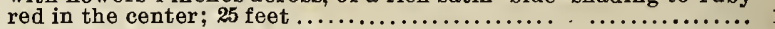

IPOM $O A$ limbata elegantissima, one of the finest $\mathrm{v}$ arieties for covering fence or trellis. The flowers are three inches across, of a lovely azure blue with a broad white margin; 10 feet,........

IPOMOA coccinea elegans, a new variety from Mexico which was introduced by me. The vine is of slender but rapid growth and very branching, climbing 15 or 20 feet. The flowers, which are nearly an inch across, are of a bright rosy crimson. They are borne on two-forked racemes which stand well out from the foliage and in such profusion as to quite cover the vines. It begins to flower in June and continues in full bloom till killed by

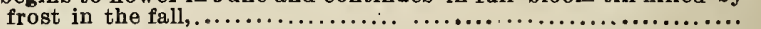

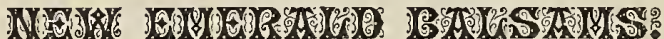

The Double Balsam is one of the most popular and beautiful of annuals, the flowers of a flrstclass strain resembling Roses and Camellias. The Emerald is a strain which $I$ bave tested for two years by the side of every strain of Balsam could obtain in Europe and America. It proved so much superior to all the others that I feel confident my customers will thank me for introducing it. Nearly every plant of the many hundreds I have grown produced flowers as large and per fectly double as Camellias, while no other strain presented such a variety of colors, which included pure white and many shades of red from light pink to dark blood erimson and many varieties superbly spotted, mottled and striped with white. The flowers are so very double and perfect that many plants did not bear a dozen seeds each, and they are necessarily more expensive than common strains. Start Balsam seeds in the house early and plant 18 inches apart after danger from frost is past. When the plants begin to branch, pinch o t the central shoot and all the branches except fc $r$ or five, and these will grow very long and be pe. cet wreaths of fiowers. If left unpruned the flo s are too much hidden by the foliage. If the flrst wers that open are kept picked off, those that ow are apt to grow more double.

Ner 'merald Balsam, all colors mixed,.. 20

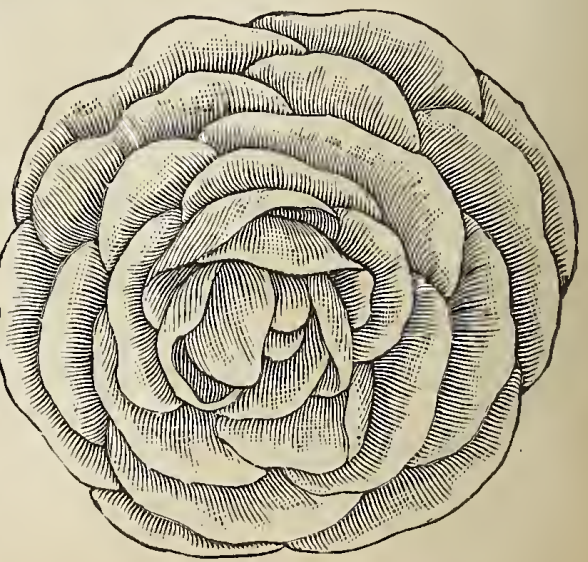




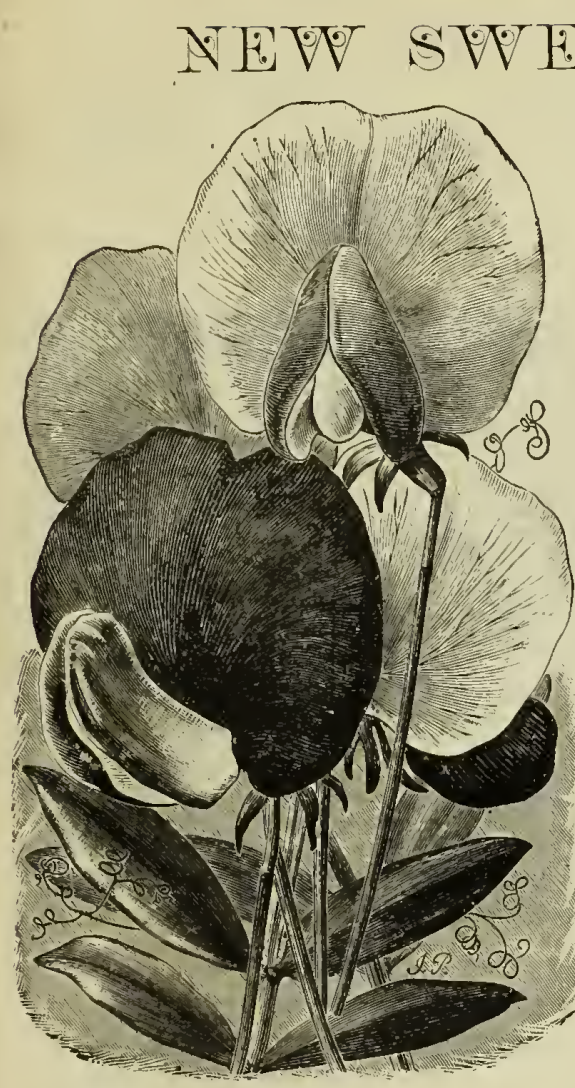

Sweet Peas have increased in popularity very lapidly during the past few years and are now among the most fashionable of all flowers. This is chiefly due to the labors of Henry Eckford of England, who has had remarkable success in improving this favorite flower, and has originated many new varieties of large size and new color's and tints.

Oueen of the Isles, striped and mottled, blue and red. Is a Lchford, creamy white, shaded rosy pink. Queen of England. large pure white. Primrose, pale primrose yellow. Grand Blue, blue and purple. Splendid Lilac. Invincible Carmine, very brilliant color. Duchess of Edin burgh, scarlet and crimson, tinted with creamy white and rose. Princess of Wales, white, striped aud shaded with mauve. Boreatton. deep maroon. Orunge Prince, orange-pink and rose. Splendor, pinkish rose shaded crim. son. Princess Louise, rich rosy pink shaded lilac. Indigo King, maroon and indigo blue. Tesuvius, rosy violet, spotted. Princess Beatrice, soft rose, rery distinct. Mrs. Gladstone, pink and blush. Lottie Eckford. white and blue. Empress of India, rosy pink and white. Apple Blossom, bright pinkish rose and blush. liss Hunt, pale carmine aud soft rose. Fairy Queen. blush and white. The Serotor, shaded and striped chocolate on creamy ground. Monarch, bronzy erimson and deep blue.

Each of the abore $\mathbf{2 4}$ rarieties, $10 \mathrm{cts}$, per packet. 3 packets for 25 ets., 7 packets for $50 \mathrm{c}$ NEW SWEET PEAS, all the abore mixed. This is the finest struin of mixed Sweet Peas ever offered. Per packet 10 cts. ; oz. 20 ets. 2 ozs., 35 ets. ; 4 ozs., 60 ets.; 1/2 lb. $\$ 1.00$ : lb., $\$ 1.75$.

Eckford's Newest Varieties: Besides the above I have succeeded in obtaining a limited supply of Mr. Eckford's newest varieties, some of which are considered the finest he has ever raised. Eight newest varieties mixed. Per packet 15 cts., 3 packets for $40 \mathrm{cts}$.

NEW SWEET PEA, Blanche Ferry: This new variety is of American origin, and one of the most magnifleent varieties over introduced. It bears more flowers on longer stems and remains in bloom longer than any other va. riety. The flowers are very large, of perfect form, the keel pure white and the wings deep pink. Compared with Painted Lady, which it most resembles, the flowers have a far richer color and greater fragrance. Per packet 10 cts. $\because$ per oz., 20 cts. ; per $1 / 4$ lb., 60 cts. : $1 / 2$ ib., $\$ 1.00 ; 1 b ., \$ 1.75$.

\section{$\rightarrow$ NELW HNNUTL}

\section{(HRNHIVIONS. .}

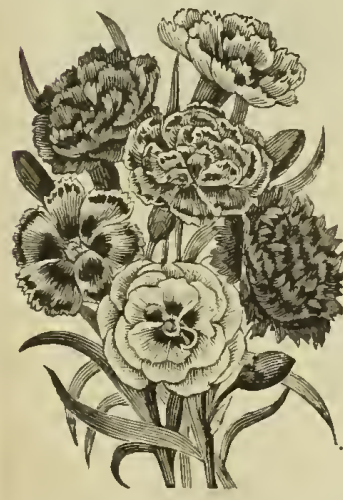

"QUEFN MHRGUERJIE.",

All will admit that a Carnation Pink which blooms freely the first year from seed is a great acquisitirn, and that is just what this new elass is. Plants from seeds sown in March bloom freelv during tne latter part of summer and autumn. The flowers are large vers fragrant and of various self colors and some beautifully variegated and strjped with white: and 80 per cent. will come double and good........ Packet 10 ets., 3 packets for 25

Pure White: This pure white variety ot Queen Marguerite Carnations is a novelty of this season which the introducer states wiil come 75 per ct. true. Packet

Marguevite Carnations, Now Dürt: These grow only to 13 inches high and are eminently suifable hoth for borders and pot culture : mixed colol's..............................

SCABIOSA, Golden Yellow joulle: A Yellow Scabious has long been looked for and this novelty which bears a great profusion of golden yellow flowers, will no doubt become a great favnrite.

TUFHED PANSIES : These are very popular in Europe for bedding, but are almost nnknown in this country. They resemble small Pansies, but they bloom much more profusely, a bed of them being a perfect mass of flowers in early spring. Suw the seeds in Ifay and as soon as large enough transplant 6 inches apart in some spot in the garden where they can grow till SeptemNEI ANNUAL CARNations. ber. After the frost has killed the ordinary bedding plants, dig over and enrich the beds and fill with the Pansies, setting them 6 inches apart. They will now he in flower and can be assorted and set according to color in bands or any designs desired.

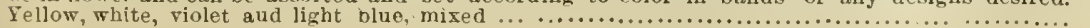




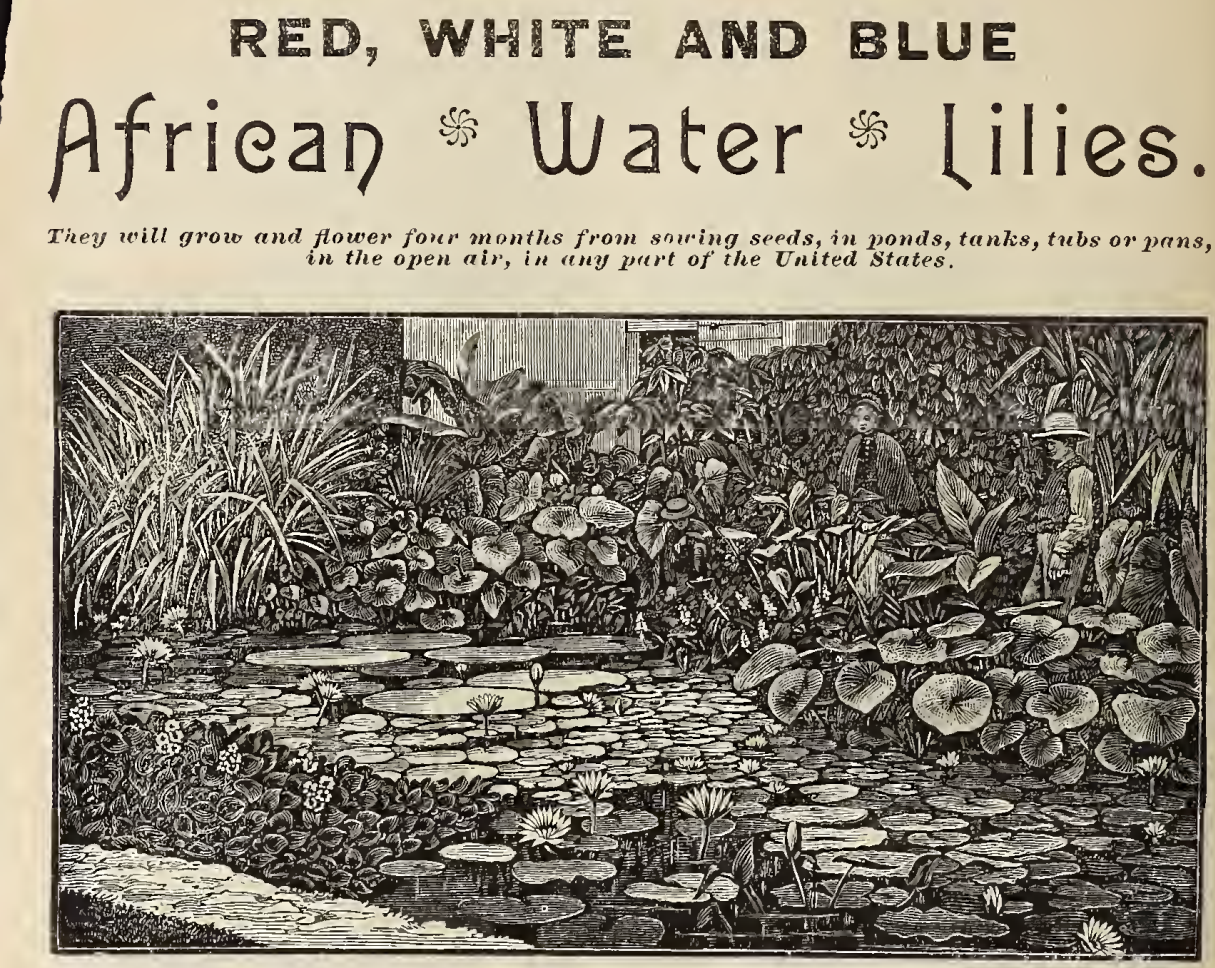

(A corner in one of the Lily ponds at Pansy Park-from a Photograph.)

It is safe to say that nothing in the floral world has ereated so much interest among lovers of rare plants as these gorgeous red, white and blue Water Lilies; and when it becomes generally known how easily they can be grown every'ody who loves cholce flowers and can have a tank or tub of water will have them. Although they are natives of tropical Africa, they can be easily grown in the open air in any part of the United States. flowering freely for several months the first year from seeds. Our natjve Water Lilies require several years to make flowering plants from seeds, but these blue and pink rropical varieties are, practically annuals, and bloom from seeds about as soon as Verbenas or Petunias and are about as casy to grow. Plants from seeds sown in the middle of March, if planted out in June make an astonishingly rapid growth and begin to bloom in July, each plant bearing from one to three magnificent flowers, which are 6 four to ten inches across, every day till frozen ' $\mathrm{pp}$ in the fall. From fifty to seventy-five flowers of these gorgeous lilies opened every day for several months last summer in the aquatic gardens at Pansy Park, from seeds sown iu March, and they were very much admired by thousands of visicors. In some ot the Southern States they will grow and flower almost the year round in natural ponds, and no doubt would become naturalized if once established. They ean be grown to perfection in ponds or large tanks, but these are not at all necessary, for they flower just as well in tubs, the only difference being in the size of the flowers. I flowered quite a number in common two-gallon pails last summer, as an experiment. The size of the flowers depends on the size of the tubs or tanks and richness of the soil. If in pails or tubs they will be from two to six inches across, and from six to ten inches or even more, if in ponds or large tanis where they have plenty of room. The seeds are about the size of Poppy seeds and never fail to germinate if properly treated, in six to flfteen days. Their eulture is very simple. Take small cups, like tea-cups, fill them about half or wo-thirds full with fine, rich garden soil, press it down hard and firm and scatter the seeds on the surface, a packet in each eup, covering them to the depth of an eighth or quarter of an inch with ciean sand. Then fill up earefully with water, so as not to disturb the seeds, and place where they will keep at a temperature of 70 or 80 dagrees till they germinate. Those who have no green-house can start them near a stove or on the mantel-piece, moving them to a warm, sunny wiudow as soon as the plants are well up. Examine often and see that the water does not all evaporate from the cups. After the plants have made leaves a quarter inch across, and are large enough to handle, transplant to three-inch pots wbich have been nearly filled with soil composed of old, thoroughly decayed stable manure and garden soil in about equal parts. Press the soil down firm and set a plant in each pot, coyering the soil with a little sand to hold it down, and put them in a pan of water deep enough to cover the plants about an inch. They ean be kept in a green-house, hot-bed, or a warm sunny window in the house until time to plant out in the tubs, which is early in June in this latitude. Tubs can be made from anv strong, tight barrel sawed in two. or molasses hogsheads would be still better; or tanks of cement can be made in the ground of any size desired. The tubs can be kept on the snrface or sunk partly or wholly iu the ground. Put them where they will get at least 6 or 8 hours of sun during the day. Fill the tubs about half full of soil composed of about equal parts of garden soil and old, decayed stable manure. firming it well down. Set only one plant in a tub and cover the soil with an inch or two of coarse sand or gravel to hold it down. Do not cover toe plants with more thau two inches of water until they liave made considerable growth. Deep water is not necessary at any time: 4 to 8 incnes is euough. It is uot necessary to change the water in the tubs more than two or three times during the summer. 
Seeds of these gorgeolls Lilies were introduced by me three years ago, since which many have tried them and they hate created a sensation wherever grown. The following are samples of many reports, which I take the liberty of publishing to show that they are just as represented.

"I was more than satisfled with the success I had with the water lily seeds you sent me last spring. The plants grew so slow at first that I thought they nerer would amount to anythiug. I set them out in June and from July to the hard frosts they were constantly iu bloom. The Howers were from six to eight inches across. I had them in barrels in a basin eight feet across. I was uever so well satisfied with any flower that I hare tried to raise, and would like some more seeds." - E. M. VALENTINE, Yankton, S. D.

I cannot omit to bear testimony to the truth of your statements concerning the Zanzibar Water Lilies. I sowed the seeds Feb. $22 d$, following your directions, placing the cups on the kitchen shelf, transplanting to tubs when large enough. On the 4 th of July the first flower unfolded its beauty and the same plant has been in flower ever since in a tank about three feet square in my conservatory. There are two open flowers and several buds on it to.day, Jan. 12th, 1891."-ARthl'R Boyle, Sante Fe, N. M.

"I bought some Zanzibar Water Lily seeds from you last spring and although it seemed a hopeless task to do so, I set to work to raise them and suceeded beyond all expectatinzs. All through the summer I had magnifient blooms of every shade of blue and red, from lightest to darkest. You cannot say too much about them, simply becanse you cannot do the subject justice." -CHAs R. SCHRIMsHaw, Mloute Sano, Huntsville, Ala.

"I wish to tell you of our success with the Zanzibar Water Lilies from seeds. I set them iu tubs the first day of June at which time the largest leaf was one inch across. First blossom the fifth of July, and from that date they were in bloom just three months, and would have opened later if the nights had not been so cold. I was much pleased with onr success."-Mrs. B. F. CrandalL, Hope Valley, R. I.

VXIPHEd Zuniburensis azuren, (Blue African Water Lily). This is a magnificeut variety, and is of all shades from lavender to a rich deep, aznre and purple. Per packet..........20

VTMPIIEA Zanzibarensis rosen, (Red African Water Lily). A rare variety and like the above in all respects except color. which varies from light pink to rosy purple and crimson. Both

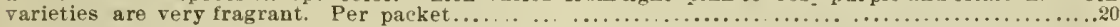

VIMPHAA dentut, (White African Hater Lily). A grand species from Sierre Leone with pure white flowers as large as those of the Zauzihar varieties. The seeds of this variety require sereral weeks to germinate, and it is best to start them as early as possible...................20

SPECLAL OFFER. For to cts. I will send one packet of each variety-Red, White and Blue.

MIXED Wuter Lily sueds. The above three rarieties mixed.

PLA NTS of Wrefer Lilies. In Iray rend June I ran supply fine plants of these Wrater Lilies at lower prices than they hate ever before been offered. For prices see PLANT DEP.ARTMENT in the latter part of this Catalog. Where also will be found descriptions and prices of ai other varieties of mater lilies, and other ruatics of which Ihace one of the most completecollections in the world.

\section{PHLOX DRUMYONDX GRANDIFLORA:}

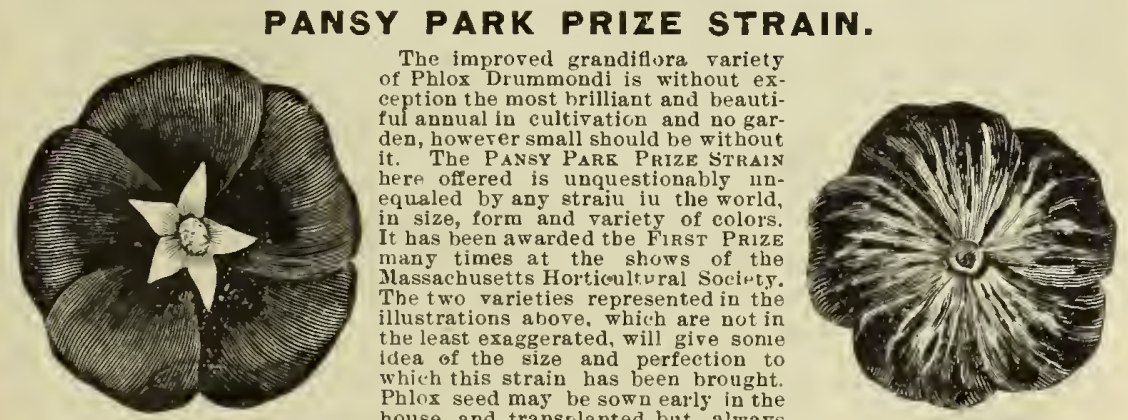

makes a stronger growth and bears larger, finer flowers wben sowu in the open ground where they are to bloom. Sow very early in spring iu drills one-half an inch deep and thin the plants to a foot. apast.

Pansy Park Prize Strain ill 30 valieties as follows;- White; White with dark eye; Deep Purple: Deep Purple wilh white ege; Deep Purple striped white; Carmine with white eye; Carmine striped white; Chamois Rose; Rearlet: Scarlet striped white: Carmine with very large white center; Rose with very large white center: Violet with very large white center; Light Yellow; Violet with brownish ceuter; Crimson striped white; Brilliant Crimsun with purple and white eye: Pink with white eye; Rose; Rose with white ere: Rose striped with white: Dark Purple with pure white center. Carmine with pure white center; Rose with pure white center; Rose Marbled; Violet Marbled: Violet with white eye; Brilliant Crimson with pure white starry center; Violet Purple. Each of the above thirty varieties in separate packets. each variety or packet.

All the above in splendid mixture.

Collection of 25 urerinties, in separate packets,

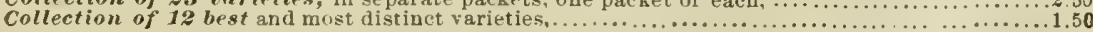

WILLARD BARRINGER. Florist. lyaton. Obio, writes :- " The Pansies growu from your Diamond strain were far ahead of any other I sowerl this season. I had seed from * * * and * *
for which great merit was claimed. but alongside of the Diamond would not bold a favoruble comparfor which great merit was claimed, but alongside of the Diamond would not hold a favoruble compar-
ison. I wever raisel larger flowers on good healthy plants. or such bright, distinct colors. shaces or marking. They gave satisfartion to custoners, and it vas a real pleasure to offer them for sale. Send me vour Price List as soon as out." 


\section{Griffin’s Unequaled Tubprous Beфonias.}

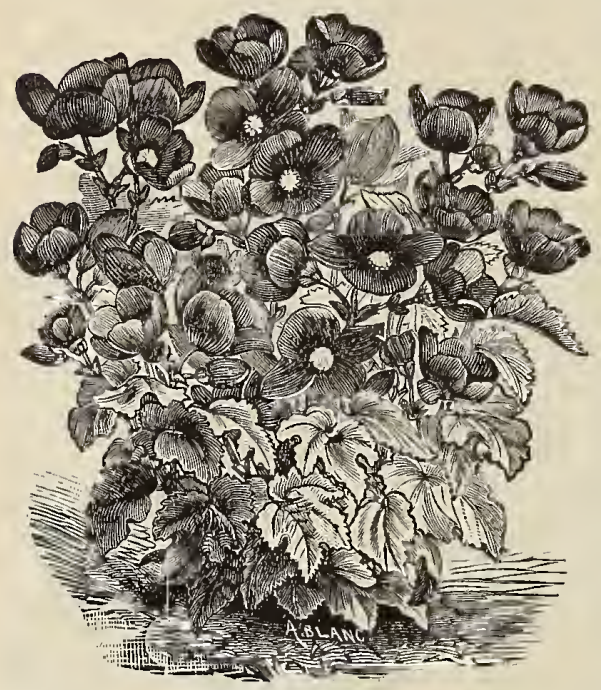

TUBEROUS BEGONIA.

This is a new Amerjcan strain of these superb Begonias that can he hedded in full exposure to the sun and is the most important addition to floriculture of the age. There is a richness and elegance ahout their flowers peculiarly their ow $n$ and their exquisite bear $y$ is not surpassed hy any flower, not even Orchids ; and the foliage is as heautiful as that of many kinds of Begonias grown for beauty of foliage alone. Wheu it is considered that they can be grown outdoors as easily as Geraniums, that they are a mass of hloom from June until the frost cuts them down, that they are unequaled for the decoration of the house or conservatory during the spring. summer and fall months, that they are superb for cut flowers and that their tuber's are as casily wintered as pctatoes, it is easily understood that thero is nothing to compare with them for general usefulness. This unequaled strain of Begonias is the result of several ycars of careful hybridization by Thomas Griffin of Long Island, and is the only strain that will sueceed hedded out fully exposed to the sun. WM. FALCONER, the well-known horticultural wrlter and superlntendent of Mr. Chas. A.Dana"s famous place "Dorsoris," writes as follows about them. "I wish you had heen with me at Westbury this afternoon where I went to see Mr. Griffin's Tuherous Begonias. They are grand. In fact [ never hefore saw the like of them. Just think of it : Twenty thousand of them all planted out in the open ground, a solid mass of handsome foliage and a sea glistening waxy hlossoms! The single flowers ranged from $31 / 2$ to 5 inches across, some of them actually in 8 asuring 6 inches, The doubles are less in diameter, say from $21 / 2$ to $41 / 2$ inches but very full and as double as Holyhock or Zinnia, and in color they run from pure white and yellow through shades of amher, pink, scarlet and crimson, many of them being of intense flery hue; and sun and rain have no deleterious effect on leaves or flowers. They are everyhody's plant and any one who can grow a Gladioius or Dablia can just as well grow this strain of Tuberou * Begonias."

The seeds germinate easily and quickly but heing very small must be sown with care as directed for all fne seeds on page 22. If wanted to flower the first season, sow in Jan. and Feh., but if sown at any time up to Jun they will form tubers for the next season's flowerlng, They can be grown in a window in a house, a cool greenhouse or a cold frame till the ist of June when they should be planted out in the beds 8 to 12 inches apart. The soil should he light, deep and rich, and the surface must be completely covered with a mulching of some light material. This is very important. Old thoroughly rotted horse manure made very fiue is best for this purpose. After frost has killed the tops take up tubers and preserve in boxes of nearly dey soil till spring. Start the tubers into growth in 3 or 4 inch pots the latter part of April in this latitude and plant out first of June. The dormant tubers may be planted out in Muy in beds. hut will not flower so early.

WPRICE OF SEED; Single Vurieties: Best quality carefully hyhridized seed that will pro-

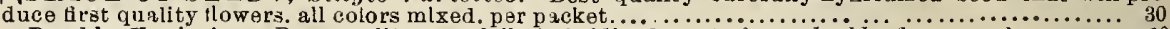

Double Varinties: Best qu ulity. carelully hpbridized seed from double flowers only........ 50

PRICE OF TUBERs; First Qurlity, single Varieties, in separate colors, Scarlets, Crlmsous, Pink: Whites, Yellows, Salmons. This quality is superior to the hest imported, no matter how high price 3 25 ets, each, 5 for $\$ 1.00, \$ 15.00$ per 100 . First Quality, Double Varieties, in separate colors. These are tirst class in every respect. $40 \mathrm{cts}$ each, 3 1or $\$ 1.00, \$ 25$ per 100 .

\section{Improved Lilliput Zinnias.}

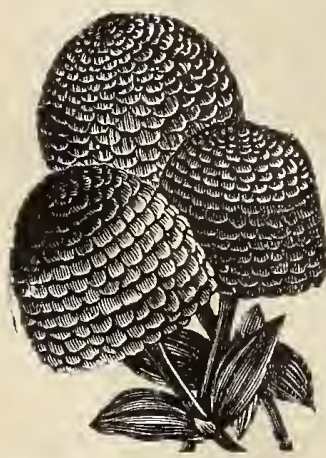

danger from frost is past.

When the Lilliput-flowered Zinnias were first introduced a few years ago they consisted only of a few dull colors. The greatly improved strain here offered is the result of careful selection and crossing for several years and contains the most hrilliant and varied colors, langing from white through all shades of yellow and red to bright crimson and scarlet. The plants form compact hushes about 18 inches tall which are covered with a multitude of perfectly douhle flowers not more than 2 inches across. For $h$-dding or cutting it is the finest of all classes of Zinnias and cannot fail to please all lovers of choice flow ers.................. 10

HUMULOS Japonicus rariegatus (Variegated Japanese Hop). A new annual climber of very rapid growth and excellent for covering arbors, etc. The leaves are beautifully hlotched and variegated with

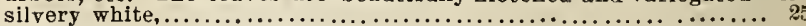

WTPHORBIA heterophylla (Mexican Fire Plant or Fire-on-theMountain). Singular half-hardy annual, three feet tall and very branching, the leaves deep green and Holly-like. During the latter part of summer and autumn the leaves on the ends of the branches turu to a fiery scarlet, some being all scarlet. others hlotehed with scarlet, the effect of this hright. color heing very striking. Start the seeds early in the house in a warm place and plant out a foot apart after Packet..................................................... 10 


\section{A STERS .}

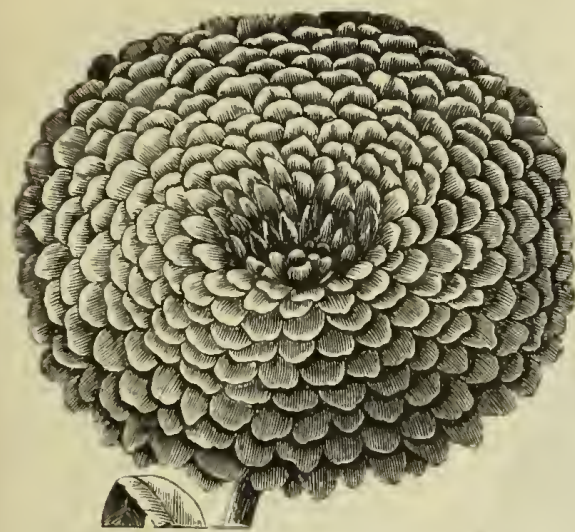

Triumple, Deep screrlet, was ittroduced from Germany and lias proved the most charming dwarf variety ever seen. It grows to the height of 7 or 8 ine es, very compact, and each plant bears from 20 to 30 very double flowers, $21 / 2$ inches across, which are of a lovely deep, satiny scar let oolor. and scarlet striped white........

Ne Plus Ultru, a new variety and one of the fluest $\mathrm{A}$ iters I have over growu. The pants are about a loot tall, each plant bearing on long. stiff stems from a dozen to twenty extr inely double flowers of the largest size and most perfect form, the petais finely imbricated and reflexed. Rose,

crimson and white, mixed............

Mignon, a very beautiful variety of wbite Aster, the plants yrowing 12 to 18 inches in height, of compact lery branching habit each plant bearing from 50 to 100 pure white double flowers about two incbes across, with the petals finely imbricated. It is one of the earliest to bloom and keeps in perfection longer than anyother variety.

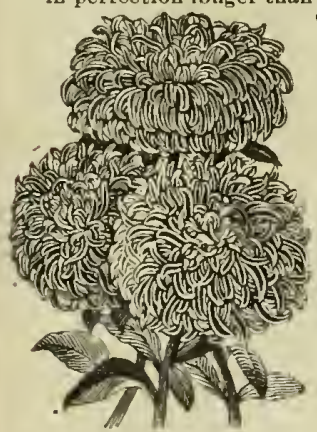

Comet, a new and very halldsome class and the most distinet that has been introduced for many years. The plants grow 15 inches tall and have very double flowers of the largest size, 4 to 5 inches across. The petals are very long, narrow and curled at the ends and have a tluffy a $p$ pea $r$ ance, something like the JapanCOMET ASTRR. ese Chrysanthe. mums "like balls of ribbons" as some express it: six conlors mixed,

Comet Pure White: A yrand novelty of this season, with very large and double white nower's.

Imbrique Pompon, flower small but very double and perfect in form, of bright colors and freely produced; a very dlstinct and fine variety: 18 inches: 20 colors mixed.

Pompon Crown, small, very double flow ers of various colors. with white centers extra fne : nixed colors.................. of dark rich velvety maroon color...........
Nothing will make such a gorgeous display during the latter part of sunmer and autumb as the China Aster. and every garden should have a good assortment of the difierent varieties, which vary very mucn in nower and habit of the plants. The Aster has been one of my leading sperialties for many years and I grow tbem by the acre. They are unsurpassed in quality by any in the world, and thousands of my customers say they are the best. Asters flower best in eool weatber and it is a mistake to start tbem too early,-from tbe last of March to May is the proper time in this latitude. Make the soil deep and rich and set the call sorts a foot apart and the dwarf six to eigbt inches.

Truffuet's Poenuy-flowered, splendid, large flowers, the petals slightly incurved: one of the very finest varieties ; 2 feet tall; 18 colors... 10 Rose-flowered, very large double flower's with the petals finely imbricated; 2 feet tall ; $15 \mathrm{col}$ ors mixed....................... 10 Rose-floreved, Dir) Scarlet: Flowers very double. of a dark cr mson searlet or maroon color. The deepest, richest colored Aster ever produced ............................... 15

Hurlequin or Jerparl. an elegant sort; the flower of nedium size, perfectly double and a large part of them beautifully spotted with red or purple on white ground; 15 inches tall 10

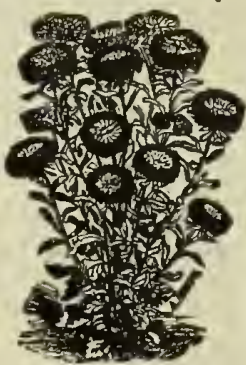

CROWN ASTEP. ted flowers; 18 and double imbricamixed...

Victoria, Light yellow, although not strict ly yellow it is the nearest approach to it yet obtained in Asters, and a desirable ad dition, being of a light sulphur color. ...

Zirngiebel's Double White, is one of the finest of white Asters. The plant is about 18 inches in height, of good habit and covered with large double flowers......

Dwarf shakespeure, Blue-bluck, a new color in Asters and the nearest to black ret obtained. Plant about 6 inches tall with small double fiowers, and so dark in color as to snnm a real black at first sicht.

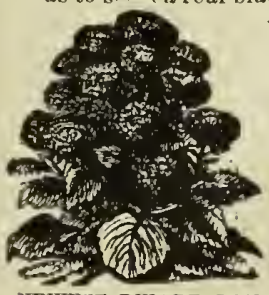

NEWEST DWARF BOC QUET ASTER. Nectest Dwurf Bouquet, a very fine variety for flling small bels, or for edging: very dwarf and com. pact ; each plant looks like a bouquet of flowers set in the ground; 6 inches; mixed colors...

illiput - flowered, bears a profusion of small double flowers mixed colors........ petals; 2 feet; nixed colors ................ Betteridge's Frize, a strong, branching plant 18 inches tall with elegantly quilled flowe $r s ; 15$ colors mixed,................
Hedgehog or Needle, long, sharply-pointed 


\section{LARGE FLOWERING}

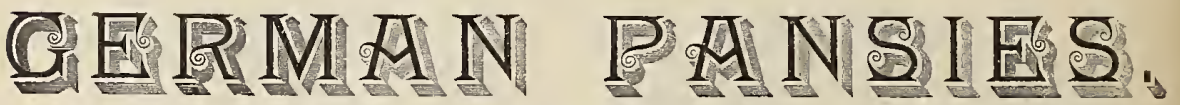

\section{DIAMOND STRAIN.}

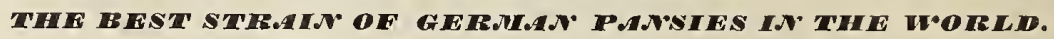

Awarded the Special Fuxon Prize by the Massachuset/s Hoticulfural Soriefy offered

for the Hest Firfy Cut Blooms Indged by a Scale of Points.

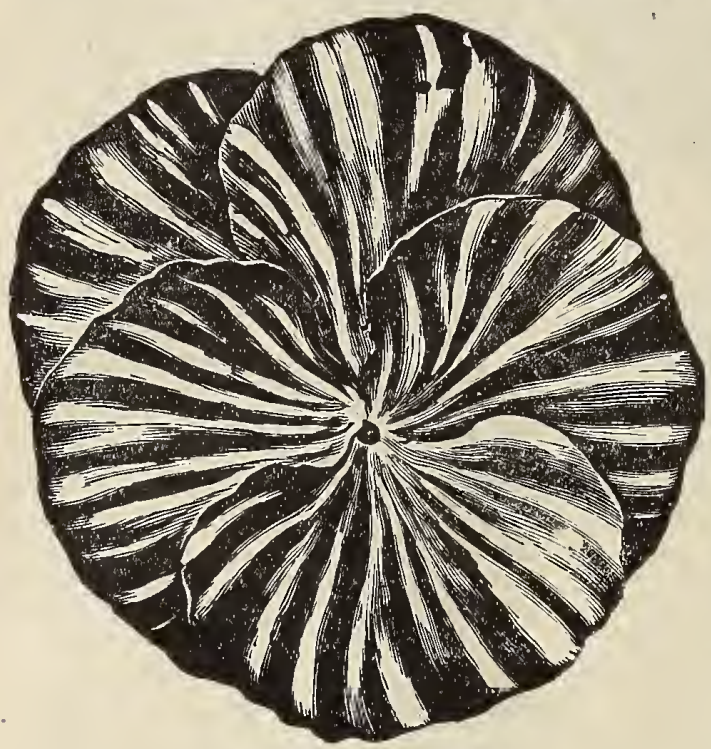

DIAMOND PANSY, PSYCHE.

The superior qualities of this unsurpassed strain of German Pansies, introduced by me, has gained such a reputation among my customers that it has resulted in the sale of over one hundred thousand packets of sceds. Its large and perfectly formed, round and velvety bloums, endless variety of rich and delicate colors and tints, often in combinations that, if not seen, would be difficult to believe ever existed in a Pansy, distinguishes this strain above all others. I grow large fields of these Pansies, which have been visited and admired by thousands of people, including many Florists. I have grown and tested every strain of Pansies offered by American, English, Scotch, Frellch and German growers and dealers up to the present time. While some of the se are excellent, none of them have proved equal in richness, brilliaucy and variety of coloring to the Diamond Strain, and none suipass them in size except the Mammoth French straius which I offer on another page. I particularly invite a coniparison with uny other strain of German Pansies, feeling confident thot the Diamond Stram will not suffer in the leant by it.

The following varieties are some of the most distinct of these Punsies, but it should be understood that while a good proportion of the plants of each variety will cone true to the description, there will always be some variation in some of the plants, but they will be none the less beantiful on that account, for new and novel shades and markings often appear. This strain of Pansies seeds verr lightly.

Melpomene, brown and fawn color; Andromeda. dark blue and black, shading to violet and azure blue on upper petals; Juno, deep. rich purplish red, with three large maroon blotches; Clymene, purple and maroon, marbled: Jralcyonc, yellow, edged with blue: Daphne, lilac shaded with rosy purple; Aurora. a velvety crimson maroon, shaded with red and edged with yellow; Iris, deep bluish purple shaded violet; upper petals light blue or violet. Eurydice, white with large blue center; Niobe, rich brown and maroon; Venus, deep rich blue and purple, stained light red and bordered with pink and white; Lavinia, deep jellow with black center; Thalia, violet and purple with yellow center; Antigone, dark purplish blue; Minerva, white ground with a large dark bloteh on each petal; Callisto, dark colors with light edges; Psyche, various shades of purple, yellow and brown striped and mottled often on a light ground; Euterpe, rich shades of blue and purple with a black center; Alcestis, various shades of purple, yellow and maroon beautifully marbled and shaded; $C y-$ bele, brown with yellow center; Sappho, purplish black with violet center; Dryope, light blue shaded with brown and fawn color; Erato, purplish black with bronze or yellow center: F lora, red with five large dark blotches; Clytip, purple or maroon center: Semele, purple shaded with violet: Iole, brown with yellow center; Dione, varions shades of purple, yellow and maroon, marbled; Hebc, yel low, stained red; large dark blotches; Calliope, rich velrety maroon and bronze color with yellow center; Calypso, mahogany color, citron yellow and bronze with dark center: Proserpine, purple and blue with white center; Thetis, red and yellow with maroon blotches; Nephele, white, sometimes marked with violet; Clio, purple edged with white: Ceres, pure white, sometimes slightly tinged with cream color; Cassiopeia, jet black with jellow eye: Arethusa, yellow with maroon blotch; Ariadne, dark purple and maroon stained and edged with red and white: Terpsichorc, white with darlk spots; Vestr, light sky blue with vielet center; Thisbc, white, curiously spotted and mottled with purple, violet or blue.

\section{PRICES OF DIAMOND STRAIN.}

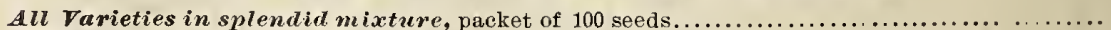
Extra Choice mixed, from the largest, fnest flowers of the richest self colors and finest fancy

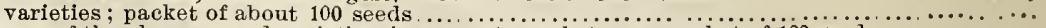

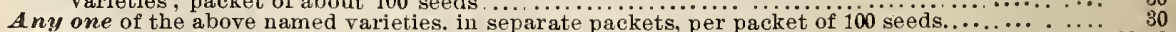
Collection of 10 named varieties, in separate packets, purchaser's choice... ............ Collection of 25 named varipties, in separate packets, purchaser's choice.................. 450

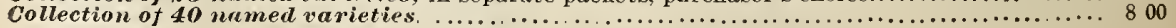

PLANTS : See PLANT DEPARTIENT for prices, page 40. 


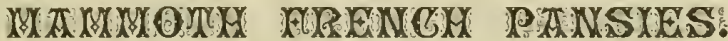

\section{FANCY STRAIN.}

This uew French Straiu is of the Odie1 type, with three or five large maroon blotebes on wbite, yellow, bluish or redaish ground. Although the colors are limited, they are magnificent, and the largest in size yet attained in the Faucy strains, growing from $21 / 2$ to 3 inches across, according to tbe culture they receive. Price per packet of about 50 seeds,............................ 30

\section{IMPROVED MAMMOTH TRIMARDEAU.}

The strain here offered is the result of several years of careful culture and crossing. The are a great improvement on the original Trimardeau in shape, color and substance of petals, wbile they are even cousiderably larger in size. With ordinarily good culture they readily grow from $21 / 2$ to 3 inches in diameter but with special high culture and pruning they grow up to 36 inches or oven more. While they do not, and probably never will, equal tbe Diamond Strain in perfect form and endless variecy of rieh, velvoty colors aud tints, these Improved Mammoth Trimardeau Pansies surpass in shape and substance, combined with enormous size, anything that bas before been offered in tbe Pallsy line. Mixed colors, packet of 100 seeds,

For 75 cents I will send one packet each of the Improved Hammoth Trimardeau, Mammoth French Fancy and Extra Choice Mixed Diamond Strain of German Pansies.

\section{HOW 'TO GROW PRIZE PANSIES.}

Pansy seeds can he sow at almost any season of the year with good success, but best from January to August. Sow in a cold-frame or in boxes, covering tbe seeds not more than an eighth of an inch with soil, and take particular care in watering and sñading to keep the soil constantly moist till they germinate, which will he in from 10 to 18 days if all goes well. Pansz seeds are very sensitive to the drying out of the soil and when they fail to germinate it is almost always from this cause, or from too high a temperature. If seeds are sown in summer the seed-bed should be entirely shaded with boards raised a few inches above the surface, and frequently examined and watered, removing the boards as soon as the plants begin to appear. As soon as the plants have grown about an inch in breadth set them 10 incbes apart where they are to bloom, or nearer if quick results are wanted. Pansles do well in partial sbade if the roots of trees can be kept out of the beds, but shade is not at all necessary, as many suppose. The soil should be made rich-tbe richer the better-with fine, thoroughly decaged manure. The Pansy is not particular as to the kind of soil provided it is rich. A very rich soil, cool weather, and an abundance of water, are the secrets of growing fine Pansies. Mere size is not now considered by Pansy fanciers a leading point in judging of the merits of blooms; tbose that are from two to two and one-half inches in diameter, if of perfect round form, witb tbick, relvety petals of ricb and varied coloring, always take the prize over larger ones that lack these points. To grow blooms of the largest size for exbibition or to astonisb your friends, make the soil as ricb as possible, select plants that have the finest flowers and pinch off all the branches except three or four on each plant; pick off the buds as fast as they appear during the summer, allowing them to bloom only wben wanted, during tbe cool wet weather of autumn and spring. They sbould be well watered during dry weather, and if with mannre water, all the better. Any of the commercial fertilizers such as guano, superphosphates, etc., if sown on the ground around the plants and ligbtly dug in, will give splendid results. Pansies usually give the most pleasure wben allowed to bloom freely, which they will do at all times if given good eulture and are not allowed to form seed which tends to exhaust the plants, and serere pruning is not recommended except to obtain large blooms. The flowers are always smallest during summer, bearing the finest flowers during the autumn of tbe first and spring of the second year, after wbich the plants become exhausted ol "run out" and new ones should be obtained from seeds erery year. Plants of Pansies are perfectly hardy in this climate without any protection wh atever, and wben ther are killed during winter it is caused. not by cold but by water settling around the stems, which causes themto decay, aud care should be taken to set plants on ground a littlo elevated or on au incline.

\section{SUPERB DOUEKE HOKWYXYOCKS:}

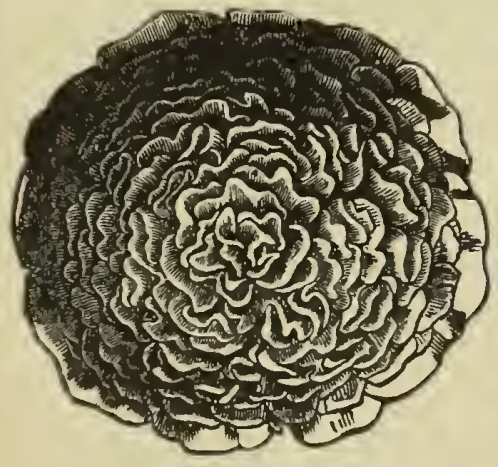

SUPERB DOCHLE HOLLYHOCF. (1/4 uatural size.)
The Double Hollybock is the most gorgeous and showy of all the hardy perennials. I have been growing and improving it for many years and am able to offer a strain whicb can be recommended as the finest extant. The flowers of largest size, perfectly do:able and range in color from pure white to deepest erimson. Seeds should be sown as early as June 1st, in this latitude. Set the plants 2 or: feet arart in a bed a little elevated above the surrounding surface so that they will keep dry in winter. Cover with a few leaves or evergreen boughs late in fall. Sixteen colors, - pure white, dark crimson, dark pink, light buff and purple tinged it lac, salmou rose, canary yellow, violet tinted with cream, light fiesh color, crimson flaked with salmon brown shaded and tipped with lilac, cream color and purple shaded lilac, buff yellow, purple, rose, sulphur yellow, scarlet-all in splendid mixture..

I'OPPY, Jupnrese Pompon; An elegant variety of Poppy growing a foot tall. The flowers, whicb are borne iu profusion, are small and double or somi-double, of the most delicate and brilliant colors, many of them with a white edge; mixed

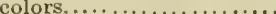




\section{Gorgeous New Poppies.}

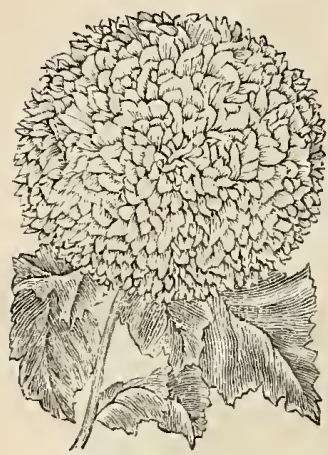

SNOWBALL POPPY.

FAIRY BLUSH: This distinct new Popny is the most desirahle of all varieties. A quarter acre bed of them at Pansy Park was the admiration of all visitors for nearly two months the past summer. The immense perfectly douhl flc.wers are three to four inches in diameter, elegantly fringed and pure white, except the tips of the petals which are rosy cream. The flowers at a little distance appear like large feathery halls overcast with a rosy shade. Packet........ 10 $S N O W B A L L$ : This grand variety bears an ahundance of large, pure white, double, elegantly fringed flowers resembling real snowballs.. FIRW BALL; Very large and double, fiery crimson.

MIDNTGHT: Flowers large, double and almost black forming a stl.iking contrast when planted with Snowhall...

YESUVIUS: Enormous double flowers, often four to five inches in diameter, of the most hrilliant scarlet, each petal striped with white.

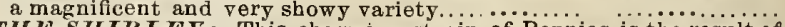

THE SHIRLEF: This charming strain of Poppies is the result of many years of careful selection. The flowers are large, single or semi-double, the range of color extending from pure white through the most delicate shades of pale pink, rose and carmine to deepest crimson, scarcely two heing alike, while many are delicately edged with a different shade. These elegant Poppies have received unstinted praise from the horticultural paper's in Europe and America

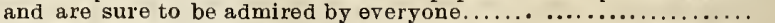

TULIP POPPY: A new and very showy species recently introduced frem Armenia. Each plant hears 50 to 60 large flowers of the most intens $\theta$ scarlet color, resembling Tulips............

SPECIAL OFFER:-One pricket each of the above seven varieties for 50 ccnts.

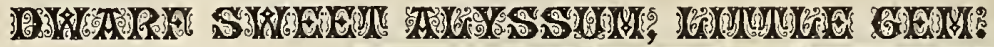

This is an exceedingly pretty and entirely distinct dwarf variety of Sweet Alyssum originated hy me. The plants are of ver'y dwarf, compact spreading bahit, and only 3 to 5 inches in height, each plant covering a circle from 15 to 30 inches in diameter. It hegins to bloom when quite smali, often when in the seed-bed, and so profusely that the plants are a solid mass of white from spring till late in autumn. I have counted over 600 clusters of flowers on a single plant at one time. For small heds and edg ings it is very effective, and for pots and haskets a gem of the first water. It is as fragrant as the common $\nabla a$. riety and hetter for cutting. Parket $10 \mathrm{cts}, 3$ packets $10125 \mathrm{cts}$.

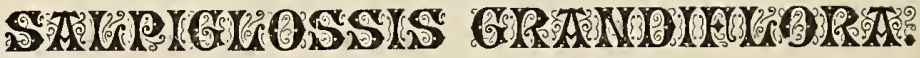

\section{Large-flowered Velvet Flower.}

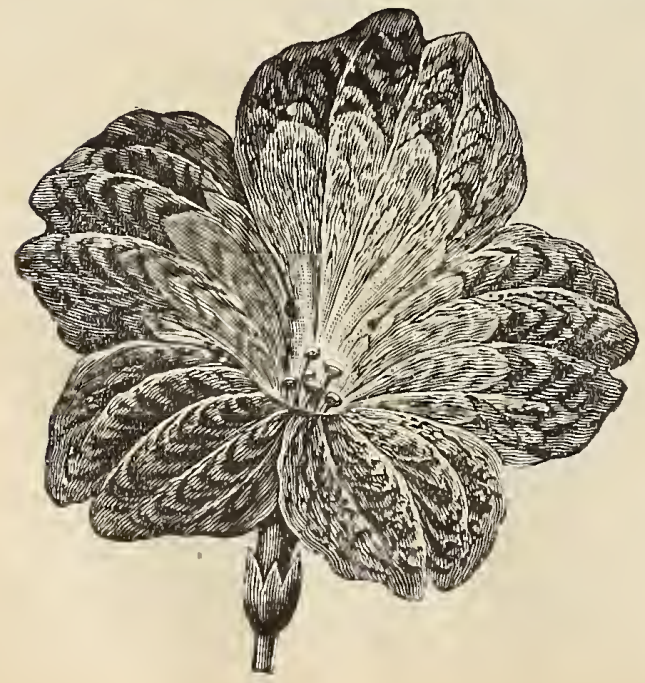

This is one of the most elegant of annuals and should be grown in every garden. The plants are two feet tall with large bell-shaped flowers which have a peculiar texture resembling that of the richest velvet, entirely unlike that of any other flower. They are of the richest colors, elegantly veined and peneilled. Seeds may he sown in the house or open gronind and plants thinned to 8 inches apart. It does best in a rich sandy soil mixed colors, .......................... 10

RICINUS Cambodgensis: The Ricinus or Castor Oil Bean is one of the most stately and ornamental of foliage plants, and this new variety has the darkest leaves of all They are of a rich greenish maroon, and the stems and veins almost black; 6 feet tall. 10 COCKSOOMIB, Fire King : The most brilliantly colored variety yet produced-a fiery

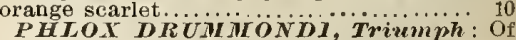
the many varieties of Phlox, this is the best of all for hedding. The plants are of semidwarf hahit, very compact, and a perfect mass of shining cinnabar red flowers........... 25 CENOTHERA roser (Mexican Primose) : This was extensively advertised last year. It has single salrer-shaped fower's 2 inche across of a deep pink or rose color and is a vely pritty plant for baskets or pots... 10 


\section{EMPEROR PETUWWIAS:}

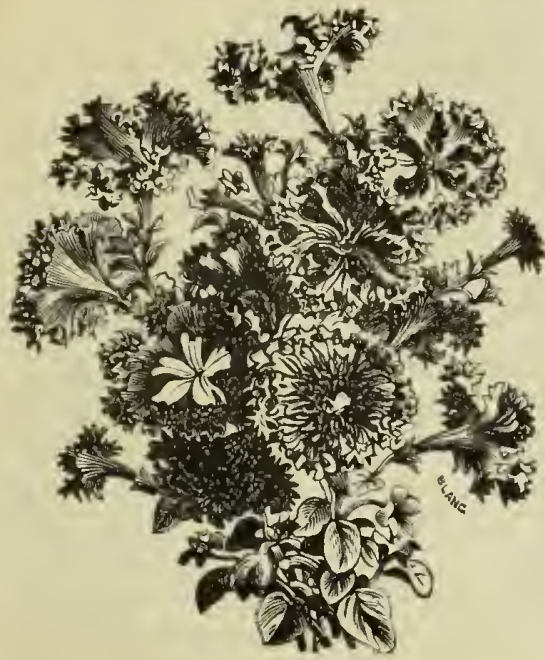

EMPEROR PETUNias (Lace-edged Section).

(Much reduced in size.)

The flowers of this unsurpassed straln exhiblt a greater variety of colors and markings than ever before obtained in the Petunia ; from the richest purple and crimson to the most delicate rose and white there is every gradation. Some of the varieties have a clearly deflned white throat, the other portion of the corolla heing colored; some are evenly or irregulaily striped, blotched and harred with purple, crimson, rose and white; others are elegantly veined with crimson, violet and maroon on a light ground, and several are exquisitely fringed and frilled, resembling ruffled lace. Many of the varieties are of very large size. These Petuuias have been awarded several First Prizes hy the Massachusetts Horticultural Soclety.

EMPEROR PETUNIAS, Lace-edged or Fringed section: The flowers of this section are of large size and of a variety of colors, pure white, white blotched, striped and spotted with crimson, rose and purple, rich cardinal red, lavender and rose beautifully veined with maroon, etc.; and the edges of the petals are most elegantly fringed and frilled resembling ruffed lace. The rare beauty of theso varieties must he seen to be appreciated. All varieties mixed............. 25 carue-towered smooth-petaled Section: Flowers of large size, the petals with smooth or even edges. It emhraces all the colors of the fringed section and many others, including several entirely new and rare varietles and shades,-rosy carmine, rich riolet purple, almost blue, cardlnal red with large white center, rose, crimson and lavender bordered with green, etc. All varletles of this section............................. 25

Small-flowered Section: The flowers of this section are small, hut the plants hear a great profusion of flowers, and ale very showy; they are of several colors, hlotched, striped, harred and spotted with white; mixell colors .... . ............ 10

Dearf Section: These are very dwarf and compact plants hearing a great profusion of small flowers of rich purple and cherry red colors with a white star iu the center of each flower. These are

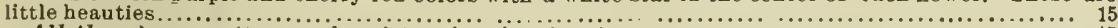

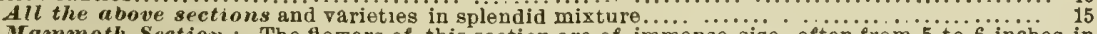

Hammoth Section: The flowers of this section are of immense size, often from 5 to 6 inches in diameter and of beautirul colors, - rose and lavender veined and penciled with crimson lake snd maroon with large tigered throats, rich shades of purple, with large white and black throats, etc. The seeds are rery sparingly produced. Packet of 50 seeds, mixed colors.

EMPEROR PETUNIAS, Extra Choice ATixed, saved from the most elegantiy fringed and finest large flowering and mammotls varieties only. This is the finest strain of mixed Single petunias ever offered and care should be taken to suve every flant.

EMPEROR PETUNIAS, Double Varieties: This is the choicest strain that can be procured and will produce from 10 to 20 per cent. of large double flowers of various colors, many of them elegantly variegated and fringed. Douhle Petunias hear no seeds and secds are produced hy crossing the double flowers with the single, whiei are grown in pots under glass, and this is a very expensive process. Seeds shonld he sown in hoxes, and particular care taken to save cill the smallest plants as these are the ones that produce the flnest double flowers. Per packet of about 50 seeds, 25 cents:

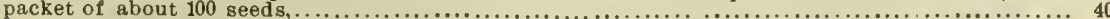

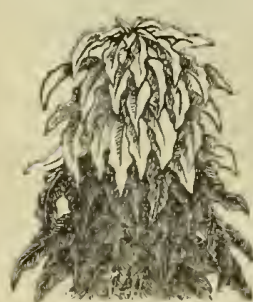

A MARANHUS SPLENDENS.
$A \boldsymbol{A} A \boldsymbol{R} A \boldsymbol{N} T \boldsymbol{H} \boldsymbol{S}$ splendens, (Rain bow Plant): This new variety is the most gorgeous Ama. ranthus tver seen, and a splendid hedding plant. It grows two feet ol more tall. with all the leaves on npper half of the plants of brilliant crimson, rose, amaranth and yellow shades, nearly every plant coming true to description. Sow seeds in the house, and plant out 15 inches apart after danger from frost is over, in soil only moderately enriched or rather poor..

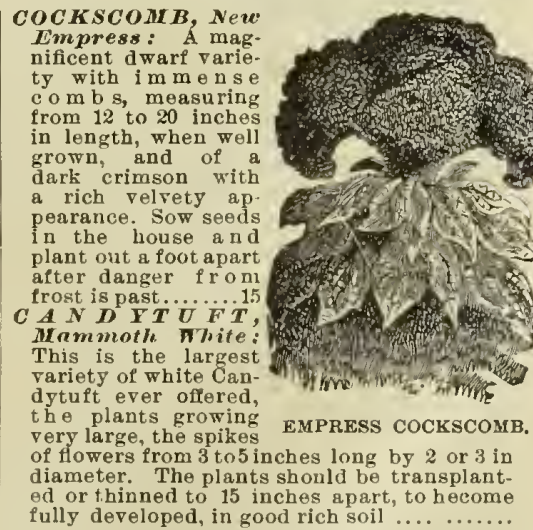
nificent dwarf varie ty with i $\mathrm{mmense}$ o m s, measurin grown, and of a dark crimson With pearance. Sow seed $n$ the house and plant out a foot apart rost is past........

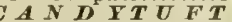
Mrammoth nhite: This is the largest er ofiered the plants growing of flowers from 3 to 5 inches $10 n g$ by 2 or 3 in ed or thinned to 15 inches apart, to become fully developed, in good rich soil

MERWIN ALLEX, FLorist, Northampton, Mass., writes :- "Allow me to congratulate you on your success in producing such elegant strains of Pansies. I buj seeds from all the Pansy specialists, hut none of them come up to yours iu size, suhstance and richness of coloring, showing that rich velvety appearance which other's fail to produce." 


\section{CENTROSEMA GRANDIFLORA.}

\section{"LOOK-AT-ME."}

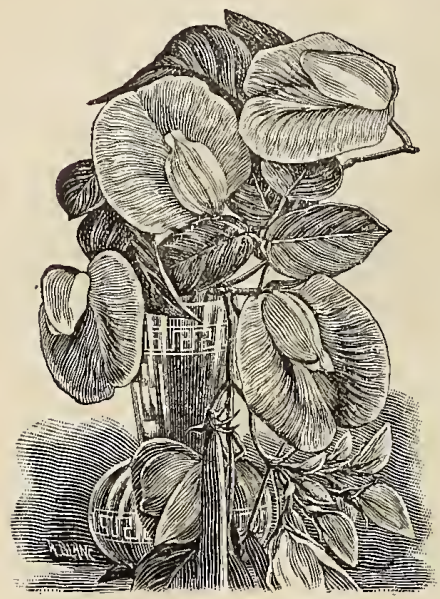

Many old and neglected plants are really valuable, and prove eminently satisfactory, but, after al', it cannot be denied that one which is absolutely new to cultivation, and at the same time is une of the rery best in actual merit, is decidedly most desirable. Just such a plant is Centrosema grandiflora and it will, no doubt, have a great run and become very popular. It is a hal $d y$, perennial rine of rare and exquisite beauty, which blooms early in June from seed sown in April, and bears in the greatest prufusio 1 inverted, pea-shaped flowers from $11 / 2$ to $21 / 2$ inches in diameter, and ranging in color from a rosy violet to a reddish purple, with a broad feathered white marking through the centre, while the large buds and the back of the flowers are pure white making it appear as if one plant bore many different colored flowers at one time. Occasionally plants produce pure white flowers, while others are broadly margined with a white featheriug. The flowers are produced in the greatest abundance, sometimes 6 to 8 in a cluster. The stem and foliage are very graceful and of a delightful odor. It is well adapted for every garden purpose, and especially as a climber, running 6 to 8 fert in a season. It will bloom until frost, and if potted, will no doubt flower freely in the house. One of its most attractive features is the way in which the flowers look up at you in the face. Every imaginative person sees faces in the Pansr, and this is even more suggestive in Centrosema. Therefore "Look-at-Me" would not be a bad name for it. Per packet, $15 \mathrm{ets}$.

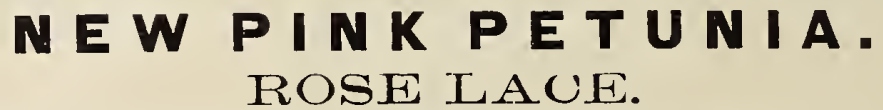

This elegant novelty which originated in my grounds is of a lovely deep pink or rose color, the edges of the petais finely fringed or frilled and often edged with white, an entirely new color in the Lace-edged varieties. The plants are of compact, even growth, and bloom very profusely. It is the best variety ever yet introduced for bedaing and unsurpas ed for pot culture...............2.

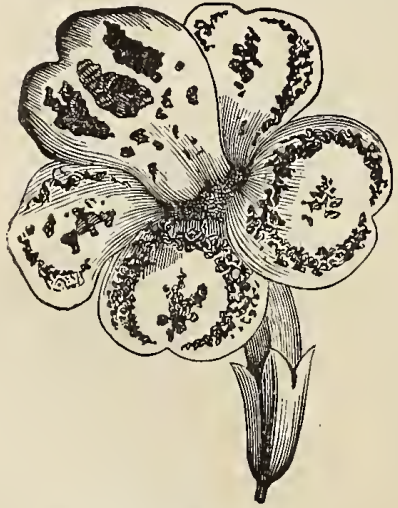

MIMULUS GRANDIFLORA.

(2-3 natural size.)

MIMULUS grandiflora, (New Mammoth Mimulusi: This is one of the very prettiest and easiest grown of house or pot plants and blooms very quickly from seed, and it is also a fine bedding plant if grown in a cool, shady place. The plants are 6 inches tall, of spreading, compact growth and bear a profusion of brilliant flowers which are curiously mottled and spotted with rich crimson-maroon on white or yellow ground, forming a most attractive combination of rich colors. Sow seeds in spring, for bedding, and in August and September for winter blooming.......... AOUTLEGIA chrysantha alba; A beautiful new pure white variety of this favorite Columbine, which remains in bloom for

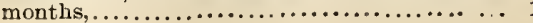

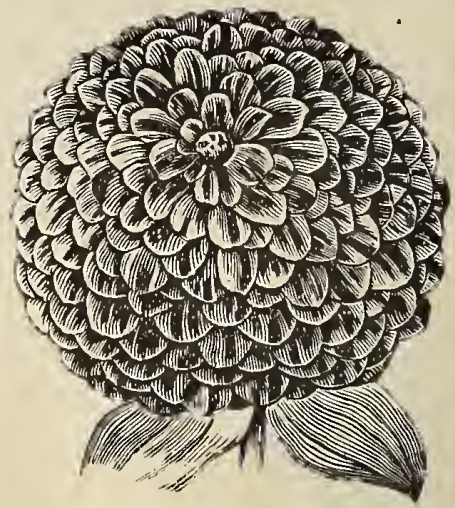

ZEBRA ZINNIA.

(1/2 natural size.)

There has been great improvement in Zinnias of late, and this new and distinct strain is the most decided break from the old style that has yet been made. The flowers are of medium size, of perfect form and of various brilliant colors, about 50 per cent. of the plants bearing flowers most elegantly striped and spotted with several shades of red, on white, yellow, rose, and orange ground; sometimes the same plants bearing both self-colored and striped flowers........ 10 


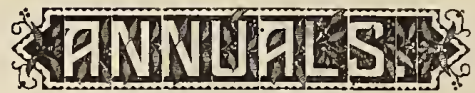

In this department will be found the older and best known varieties, embracing besides the true Annuals some Biennials and Perennials that flower the first year from seeds and are commonly treated as annuals. The flgures on the right of the columns give the price of each variety per packet, in cents.

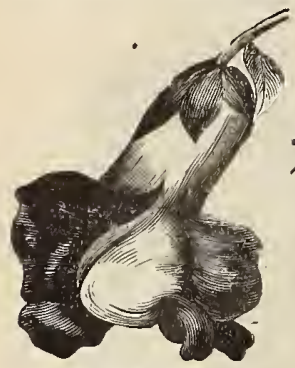

ANTIRRHINUM.

(Snapdragon.)

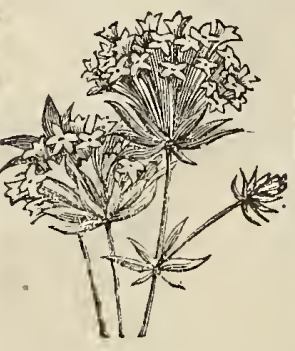

ASPERULA AZUREA SETOSA.

ANTIRRHINUM majus, (Snapdragon): One of the best and most popular of the hardy perennials; blossoms abundantly all summer and until hard frost in autumn: flowers in spikes and very brilliant. Plants may be set 8 or 10 inches apart. Ten of the best and brightest varieties mixed.

5
ingly pletty hardy annual, as useful as Sweet Alyssum, producing clusters of small, lightblue, sweet-scented flowers in profusion: about 10 inches in height, and plants may stand 6 inches apart....................

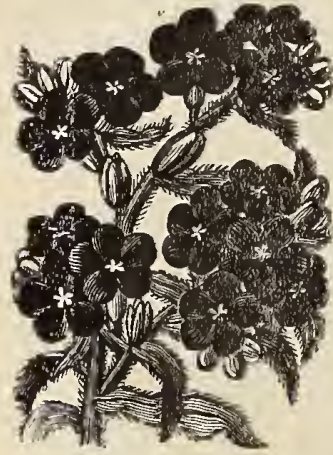

ANCHUSA capensis, (Giant F'orget. me-not): An easily grown plant, with small, deep, rich blue flowers; most excellent for cutting: about 18 inches $t$ all; $s$ e $t$ plants a foot apart .......... 10 ALTSSUII marit imune, (Sweet) Alyssum): A well known hardy annual, with clusters of small, white flowers all summer; good for beds and $\rho x-$ cecdingly fine for bouquets.........

ANCHUSA CAPENSIS.

AGERATUAI: Pretty, hardy annual, with abundance of flowers through the season; fine for bouquets; four colors mixed...

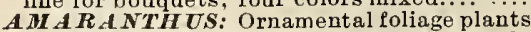
producing a fine effect when grown in beds or masses. The leaves are maroon, red. green and yellow, often curiousl 5 variegated. Do best in soil not too rich: mixed varieties AMBROSIA Mexienra: Bears graceful sprays of small, greenish flowers gond for

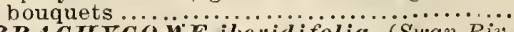

BR ACH Y C O er Daisy): A very pretty little hardy annual, producing an abundance of white and blue flowers : 8 inches : mised colors............. $\boldsymbol{B} \boldsymbol{A} \boldsymbol{L} \boldsymbol{S} \boldsymbol{A} \boldsymbol{M}$. The Balsam is a magnificent half. hardy annual, the tall varieties growing some 2 or 3 feet in height, and in bloom from June till frost, the branches being completely corered with flowers which resemble Roses and Camellias. It is hest to start the seed early in boxes or a frame. Set the plants 18 inches apart in good rich soil. The Balsam should be well pruned or the flowers are ton much

hidden by the foilage; a good way is to pinch off all the sicle branches as fast as tbey start, leaving inly the central shoot, which will grow vers tall, and be completely corered with flowers.

Camellin-Howpred Perfection, a greatly improved strain. Pure white, pink, crimson, rose. mauve, scarlet, white striped and spotted lilac and purple, crimson mottled i hite, scarlct mottled white, pink mottled white, scarlet mottled white, all colors,....

Camellia-fl. Perfection, White, a perfectly double variety and the finest white Balsam, nearly every plant producing flowers as large and double as Camellias. Very valuable for florists' use..................

Calendula: An old-fashioned very hardy llower known as the Pot Marigold, the modern double varieties of which are among the most showy of garden flowers, bluoming from July to Norember.

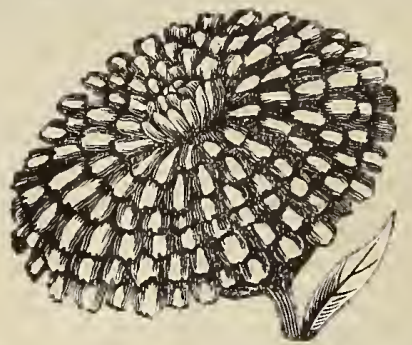

Officinalis Meteor, very large imbricated double flowers, creamy white, each petal erlged with yellow,....................... Prince of Orange, like the above, except that the stripes are of a deep orange color giving the flowers a very striking apjearance oriole, a magnificent liew variety with rery large and double llowers of a deep, clear orange color, .........................

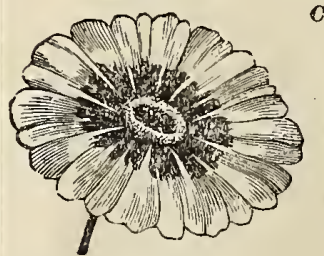

CALLIOPSIS very showy class of hardy annuals, blooming abundantly; flowers of a great many shades of yellow, orange and $\mathrm{rich}$ brown, of ten finely spot ted. Tho plants grow from 1 to 2 feet in height and $m a y$ be $s e t$ about 10 in $\mathrm{eh} \theta \mathrm{s}$ apart; mised colors, ......................

CENTA UREA (Bachelor's Button): A wellkuown old fashioned flower, the colors varied and bright, unsurpassed for cutting. Seeds may be grown whele thay are to flower and the plants thinned to a foot or more apart ; mixed colors ..................................

CHRTSANTHEMDM tricolor (Annual Chrysanthemm): Ters showy and double flowers of rarious color's, blooming all summer: mised colors .. ................. 
CELOSIA cristutu (Cockscomb): A very curious half-hardy amnual, blooming from July until frost. They should have good rich soil, and will well repay any extra care given them in the iucreased size and beanty of the combs. Set plauts 15 iuches apart; mixed colors....

New Japan, a very beautifnl variety, the combs delicately cut, and of the brightest scarlet and erimiou: to 3 feet tall

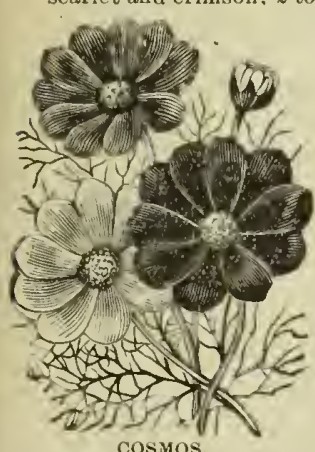

cosmos.
COS M OS hybrialus grandifloras: Fine aunuals growing 5 feet tall with elegant fol i a ge and bearing a profusion of llowers late in the fall, resembling single Dahlias. $\mathrm{Th}$ e colors are wbite a u d various shades of rose a u purple. rhe $\boldsymbol{y}$ do not llow e r w e 11 north of $\mathrm{New}$ York unless started $\boldsymbol{v} \in \mathbf{r}$ early...........

CINERARIA maritima, (Dusty Miller): A beantiful white-leaved foliage plaut nuch used for bedding. Start seeds early under glass, .....

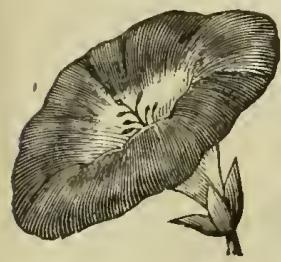

C $\mathrm{O}$ N $\mathrm{V} \dot{\mathrm{L}} \mathrm{i} \dot{\mathrm{U}} \ddot{\mathrm{U}} \mathrm{s}$ $m i n o r$, (Dwarf Morning Glory): One of the prettiest of hardy aumuals, produciug an abundance of flowers through the s u m mer and au. tumn. The plauts a 1 e of spreading habit, aud may be set 15 inches apart. Blue, white, lilac, ete., mixed,........ CONVOLVULUS MINOR.

\section{$C H R Y S A N T \ddot{H} \ddot{E}-$}

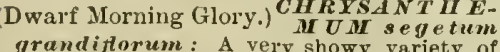
annul Chrysunthemum. The flowers are single, 11/3 to 2 inclies in diameter, of a bright golden yellow color and borne in the greatest profusiou from June to October: 3 feet tall and plants should be set 18 inches apart. This is the best yellow bedding plant 1 have ever seen. and is of easiest cultule...............

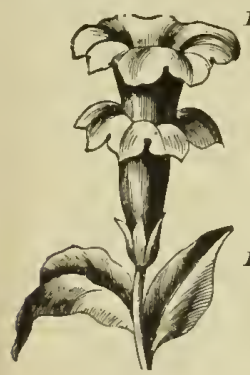

DATURA.
D A $\boldsymbol{T} U \boldsymbol{A}$ : Large branching plants about two feet tall, with mag. nificent yellow, violet and white trumpetshaped, sweet-scented flowers from $;$ to 9 inches long. Start the seeds as early as possible uuder glass. Double and single, five varieties,

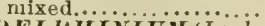

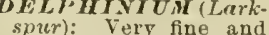
showy bardy annuals. with long spikes of flowers, and of the easiest culture. Sow as early in the Spring as possiand thin to 8 iuches of the fiuest louble rarieties aud colors, all mixed.

formssum, a spleudid havay perensial, producing spikes of flowers which are of one of the most beautiful sliacles of blue knowu

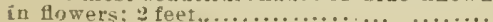

CANDTTUFT: Au old and popular hardy annual of easy culture; makes beautiful beds and is indispensable for bouquets. Seed should be sowu very early in spring, where they are to bloom, and the plants thinned to six inches. Six varieties, mixed............ Dwarf White, exceedingly fine variety, each plant forming a compact bush 4 or 5 inches tall and a foot in diameter, completely covered with clusters of white flowers, remaiuing in bloom much longer than the old sorts.

$\boldsymbol{C} \boldsymbol{A} \boldsymbol{N} \boldsymbol{N}$ : Beautiful foliage plants, with large, broad leaves and scarlet or yellow flowers. Soak the seed in warm water until the sprouts start, and sow under glass early; many varieties mixed....................

FACALIA. (Tassel Flower): Tassel shaped, scarlet aud yellow flowers; 18 iuches tall;....

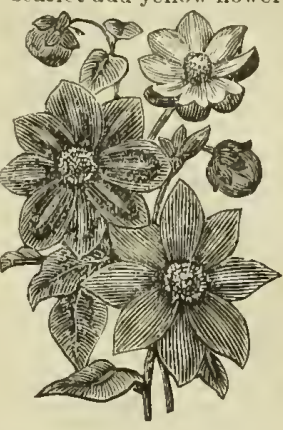

NEW SINGLE DAHLIAS. popular flower is easily grownfrom seeds, which germinate as freely as Aster or Zinnla seeds, and if started early in a frame or in boxes in the hous $\theta$, bloom almost as earls as plants from the tubers, and frequently produce as fine Howers. Seeds saved froma large collection of the finest $n$ a med double varieties, New single: Tho new single varie.

ties of Dablia highly have become very be highy recommended for bouting, and are especially valuable for all the colors of the double varietes Finest mixed, from the largest and best collection

in Europe......... ...................... species of Dahlia. 'The flowers are on long, wiry stems, are about two inches across, and of the deepest, richest maroon color, almost black, a color very rare in flowers. It is remarkably fine for cutting............

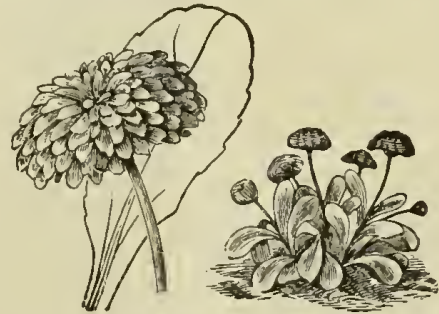

DOUBLE DAISY.

DOUBIT DAIST, (Bellis perennis): A well known hardy little plant, with small, neat double tlowers in fall and early spring. Seed should be sown as early as possible, and the plants set 4 or 5 inches apart, in a cool, shady place. Best German seed, mixed colors,. Sinoibull, uew, with large, double pure white flowers on long stems,

Lnngfelloxe, a new rariety with large red

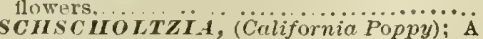
ESCIISCIOLIZIA, (California Poppy); A orange and white llowers. Sow seeds early where the are to bloom; mixed colos ,......

EUPIORBIA marginata, (Snow on the Hountam): Afine toliage plant, the leaves on the top of the plants inargined with pure 5 white; 1 inches tall,.................. 


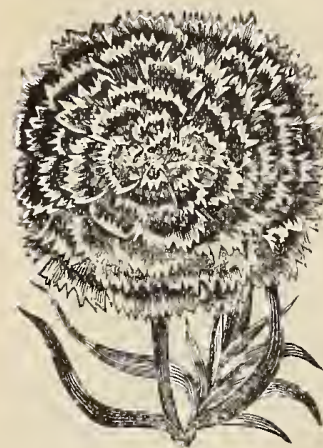

MULIRING CLUAK.

(1/2 natural size.)
DIA NTHUS, (Whince and Ja: pan Pinks): mong the most popula $x$ and beautiful of snmmer blooming thowers. The colors are very and they flower freely all summer, and sometimes thesecond summer also if the plants are not exhausted by flowering the first. They are of easiest culture, growing 10 to 15 inchts tall in any good soil, and may we set 10 iuches apart. The seerls stould be sown early in April, in this lativule. My collection of these is noted for being the largest and finest in America, anil has beeu awarded the First Prize six years in succession, every time it has been exhibiter, by the Massuchusetts Horticultural society.

Chineusis, (China Pink), small double flowers in large clisters; nixed colors,. ....... Chinensis albus $\boldsymbol{A}$-pl., double white,.... nanus roseus fl.-pl., rose color,........ imperialis, (Inuperial Pink), double mixed imperialis albus, $t h-p l$., double white,. Heddewigi, magnificeut single flowers from 2 to 3 inchus across and of the richest col-

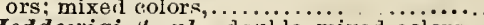

Heddewigi $\boldsymbol{t} .-p l .$, double, mixed colors,.. atropurpurius fl.-pl, very large, rich dark red double flowers, $. . . \ldots \ldots \ldots \ldots . . . . .$. albus $f .-p l$., large doublo white, ............ nanus ribus $\boldsymbol{H}_{.-p l} \boldsymbol{l}$, very dwarf, with large double white flowers,................ blood red,............................ diadematus $\boldsymbol{f}$. .pi., (Diadem Pink), iarge double fluwers of the most brilliant markings and rich, dazzling colors; mixed colors,

Eastern Queen, very large white, beautifully marbled with rose and crimson; extra fine, ...................................... very large fiowers of the richest, deepest crimson; splendid sort,... The Bride, new; large white, witl a crimson maroon zine, .............................. ers of a deep maroon, almost black, edged

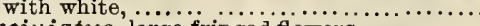
laciniates, large fringed flowers,............ and deeply fringed fowers; mixed colors,.. atrosanguineus $\boldsymbol{f}$.-pl., large, double, dark blood red fringed flowers........... striatas f. $-p l$., duuble striped; extra,....

All the above in splendid mixture,... .

GAILIARDIA, (Blanket Floner): one of the most showy of the hardy annuals and an excellent bedding plant, bearing an abundance of large red, yellow and maroon flowers all summer; about a foot tall. and plants should stand a foot apart; mixed colors..............

GARDOQUA betonicoides: A plant about 18 inches tall with very fragrant foliage and spikes of small reddish flowers; flne for bou-

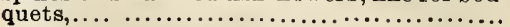
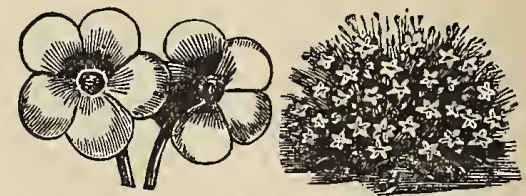

FENZIIA dianthiflora: A pretty. profuse flowering little plant abuut 3 inches tall, $n$ ith rosy purple flowers; excelient for baskets or edging to beds. Sow seeds where they are to grow and thin to 3 inches apart, . ..........

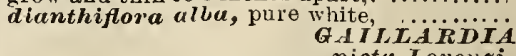
pictu Lorenziana $f-p l:$ 'This has proved one of the most valnable hardy garden floners introduced for many years. The plants grow ahout 18 inches tall, rery bushy and the flowers, which ar $\theta$ in large globular and semi globular hiads are jroducul freely f'um June till late in the fall. It is a first-class beduing plant very fine for cut-
(1) REIANA.

(1/4 natural size.) grow on long wiry stems. Sow seeds in frames or boxes it possible and transpla.nt where they are to bloom, a foot apart Orange, sulphur jellow, amaranth, claret and variegated, mixed................. 1

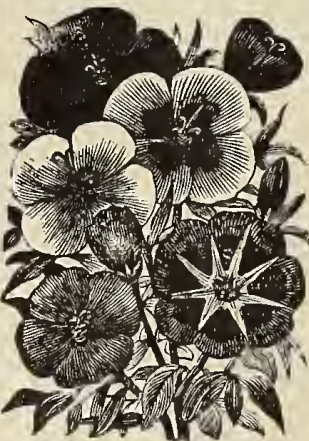

NEW GODETIAS.
G O DETIA $\mathrm{S}$, Nrw Vurieties: The new varie. ties Godetias are i $\mathrm{m} \mathrm{p}$ r o ve ments on the old sorts. The plants grow about 18 inches tall, rery com. pact and bushy and a 1 e completely covered with large $A=a-$ lea-like flowers of a peculiar sat. iny appearance, ea c $h$ plant $1 \mathrm{e}$ sembling when in full tiloom a min. iatule Chinese Azalea. They do luest when sown where they are to grow and thinned to 10 inches apnrt. Satin rose, crimson, carmine, white, triped and many other varieties, mixed................ 10

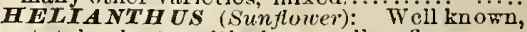
stately plants, with showy yellow flowers.

Double, flnest double varieties. mixed,......

cucumerifolius, a dwarf, very profuse blooming species, the flowers rabout two inches across, and excellent for cutting.... 10 argophyllus (Silver-leaved Sunflower), very ornamental, with soft downy, whitish foli-

age $, \ldots \ldots \ldots \ldots \ldots \ldots \ldots \ldots \ldots \ldots \ldots \ldots \ldots \ldots, 10$

Giant Rissian, of mammoth size,...... 5

I sowed over 30 different kinds of your seeds last season and they all came up so gond that it saemed as though nearly every seed must have grown, aud the flowers were very nice. The Rose-fowered ocarlet and Mignon White Asters were especially nice; a round bed of them with the scarlet ones in the center attracted the attention of all passers.by. And such Petunias, Jaran Pinks, Calendulas, Phlox, Poppies, Verbenas, Pansies don't know where to stop, they were all so nice. - IsABEL D. Dunbar, Alba, Pa. 


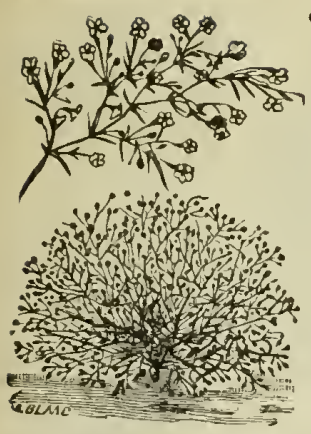

GY PSOPHILA MURALIS.
GYSUPHLLA:

(Mist Flower, Very pretty haray anuuals, beariug numerous and very graceful sprays of small llowers; very fine for beds or border, and indispeusablo for bot1quets. Sow where they are to grow. m " $*$ u $i s$, dware, rompinct, insliy plant with leautiful pi u k blossoins.

elegrars, about 18 inches tall with whit ish flower's...

LIMNANTIES Douylusi: An exceodiug ly pretty hardy auual, witl handsome daisy like flowers, cauary yellow with a broad white inareiu; 6 inches tall...

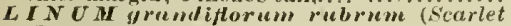
Mlax): Showy, Plilox-like Howers; 1 foot,...

EUPINUS: The auuual Lupins are very showy plauts with loug spikes of pea-shaped Howers of various shades of blue, purple, yellow and white. Plant where they are to grow; 30 sorts mixed,

LORELIA: Beautiful hardy aunuals, bearing a great uumber of small, richly-colored How "s. Exceedingly flue for baskets or edging $t$, hods. About 6 inches iu height, and plan. should be set 4 or 5 inches apart.

speciosu, sky blue, white eye,

erines companta, nltra-narine blue,...... eriuus compucta oculutu, dark blue with

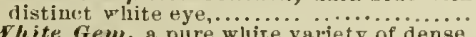
White Gem, a pure whice variety of dense,

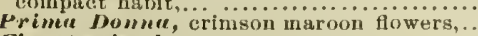

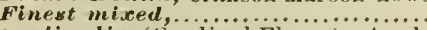

curdiulis, (Cordinci Flower): A spleudid hardy perenuial with spikes of brilliaut dark scarlet flowers, blooming the first sea. son if sown early under glass. 2 feet,

$\boldsymbol{L} \boldsymbol{Y} \boldsymbol{C I} \boldsymbol{Y} \boldsymbol{I}$ S: Handsome and showy hardy pereunials. Sow seeds early.

Chulcedonica, scarlet and white, mixed,... yrandiflore, very lalge and brilliaut; 10

inclues tall; scarlet, vermillion, rose, onnge, white, etc., mixed..

$M A L O P E$ yrumifiom: A splendid hardy plant with large purple aud white flowers. Sow seeds early: two feet tall.

MI II UL US, (Monkey Flnwer): Very eree-flowering low plants with elegantly spotted flowers; spleudid for honse cinlture and good in the garden. Sow seeds iu the house.

hybrielus tigrimus, spleudidly spotted.... tigriuus H.-pl., donble, brilíant yollow, spotted, striped and mottled with crinson, moschetus, (Musk Plunt), yellow........... is nothing fiuer than the Murigold. The Afrjcail are tall, with large flowers, and the French varieties bear unmerous small, double Howers, often finely striped with brown.

African Murigold, Huest mixed, .

French . Vuriyoll, tall sorts, finest mixed.. French Muriyold, (lwarf sorts, finest mixed, sigurata pumilu, (Golden Ring), one of the best yellow bedrling plants I bave ever seen. The plant grows very compract and bushy, 18 inches tall with elegaut Fern-like foliage and completely covered with small single flowers of a golden jellow color with an arange center.

DIDISCUS carriees: An elegant annual two feet high with umbels of sky blne tlowers,

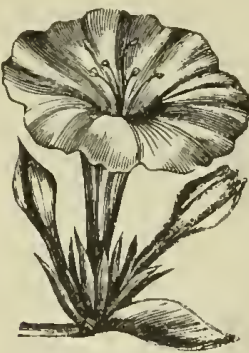

MIRABILIS JALAPA. $1 / 2$ natural size.
HLRABLLISTULUpa: This old gur deu favorite, polrularly called Marvel of Pern and Font O'clock, is one of the most ornanental of flowering plauts, $1 \%$ sembliug in its halit of growth and form of it s bright and varied colored! Howers, the beantiful Chiuese Azaleas; 2 feet tall; 8 varieties, mixed.....

MIHA 3 I L LS loregiflora (Jockey Club): A species of trailing babit with long. tubed very sweet-scented purple and white Howers, a single bed filliug a whole gardeu with fragrance similar to that of tnberoses,

MIGNONETTE, sweet, (Reseda odorata): Well known fragrant, hardy annual,.........
Mriles' spirel, oue of the best. 'The plauts Mriles' spiral, oue of the best. 'The plauts are of a compact habit, with long spikes
closely set with Howers. Plants should stand at least 18 iuches apart to beconie fully developed,......................... Golden Qreen, is oue of the best and most distinct varioties of Mignonette, the flower's beiug of a rich yellow tint and very fragrant......................

ncehet, a variety of very dware vigorous growth with massive spikes of doliciously scented red tlowers, the best of all sorts for pots................................. Fariety growing three feet tall with long spikes of white flowers often a foot or more in length which have the fragrance of "new mown hay." Set or thin plunts to 18 iuches apart

SHELL FLOWER. MOTUCWLLA Tovi.

pulustris, (Common forget-me-not), white and blue.................................... (Ever from early spring to alltumn..............

"lissitiflor", (True Large-fl. Forget-me-not, large siky blue flowers,

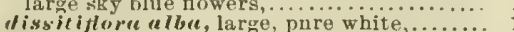
azuricu, very large flowers, dark blue, sky blue and white, mised, (Shell Flower): A very al, a native of Syria, with curious shell-like HYWSOTIS, (Forget. me-not): Well known hardy perennials, with clnsters of small delifirst season if sowu early.

alpestris, blue, white aud rose mised..... alpestris gramalifo$\boldsymbol{r} \boldsymbol{\alpha}$, very large, sky 10

OXdLIS cormiculutu purpurea: As a dwarf purple-brown foliage plant, this is unsurpassed. It was oxtensively used in the Buston public gardens last season in bedding with admirable effect. For horder's to beds it is particularly valuable. Plants may beset 4 or 5 inches apart and will soon carpet the grouud with rich purple-brown leaves and

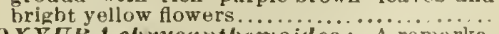

OXYUKA chrysunthemoides: A remarkably fine and very hardy plaut, with Daisylike lemon yellow flowers, edged with white 1 foot in height,.......... 


\section{MESEMB R YA NTHEHUM erystallinum} (lee Plant): A curiuus hall hardy auual. 'The leaves seem to be covered will arystuls of ice; of trailing habit; very fine for bas kets,..

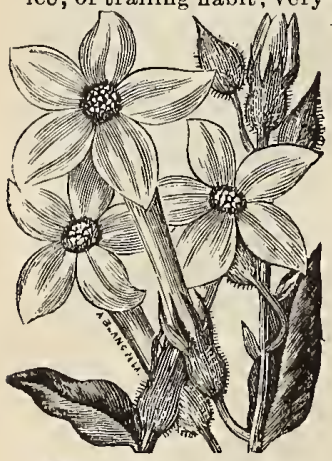

NICOTIANA AFFINIS,

(1/ natural size.) lants can be taken up in the fall, cut back and potted for the house, where they will bloom freely all winter. Seed are rather slow and uueven of germination and should be sown in a frame or box,$\ldots \ldots \ldots \ldots \ldots \ldots$.

NEMOPUILd : A vel'y pretty hardy annual, producing a profusion of small white and blue edgerl and spotted flowers; about 6 inches his $h$. Sow seed as early in the spring as possible, in a cool, shady place, and thiv the plants to 5 inches a part; 8 colors mixed,.

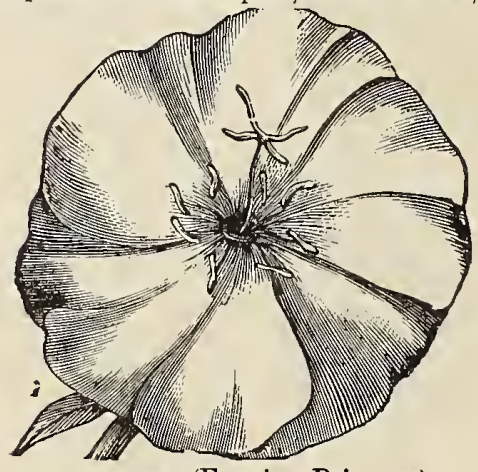

CENOTHERA (Erening Primrose).

C NOTHERd, (Evening P'rimrose): Show hardy plants, which open their flowers suddenly about $60^{\prime}$ clock in the evening.

acaulis alba, a very dwarf plant, producing exceedingly beautiful pearly white flower's,

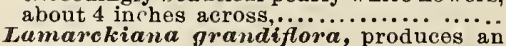
abund ance of large, zellow flowers, 4 inches across; very showy, hardy biennial, blooming first season if sown early,............

PEIRILA. This although but little known or cultivated, is the very best dark-leaved foliage plants for bedding I have ever seen, the leaves being of a dark bronzy purple almost black color. It resembles the Coleus and is much easier to grow, flourishing like a weed. Two feet tall and very branching. Sow seeds early under glass.

Nankinensis, smooth serrated leaves......

Nankinensis laciniatus, elegantly cut fo-

liago,...................................

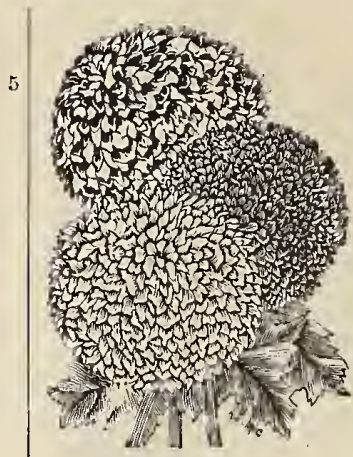

POPPT, (Papa ver): This old and well-known flower, like many other old fashioned flowers, has been' much improved of late, a usl those who have not seen the modern varieties would be sirprised at the great improvement make. 'The flowers are now as large and showy asPeouies very double, and of great variety of color. Sow seeds early

IMPROVED POPPIES, where they are to grow and thin to ten inches apart. Choicest mixed, of every variety and shade.......

PAPAVER umbrosum: A gorgeous variety of Poppy with very large single flowers of au intense dark scarlet color with a large coalblack spot at the base of each petal. Plants from seeds sown in spring flower from July to Oct., and if' sown early in Sept. tlie plants endure the winter and make a grand show in May and $J$ une..........................

PANS , (Viola tricolor): The Pansy may be called a perpetual bloomer, for a bed is never without flowers from earliest spring till late in autumn. Plants from spring sown seeds produce their finest flowers in tho autumn of the first and spring of the second year, after which tho plants beaome exhaust$\theta d$, and new ones should be obtained from seed.

Pansy, commmon mixed, a fine variety,... Diamond strain, the fiuest ever offered.

(See novelty list for descript ion and prices.) Ifrmmoth French. (See list of novelties and specialtit:s fur prices, \&c.)

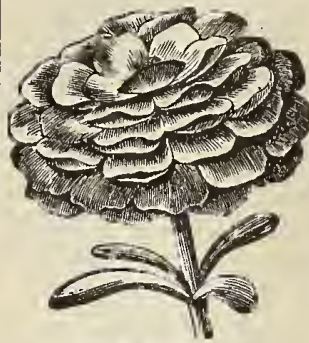

DOUBLF PORTL LAC. $P O R T U T A C A$ orandiflora: Fin brilliant dazzling colors, nothing can excel a bed of Portulaca w $h$ e $n$ in $f$ ull bloom. The colors are numerous and produced in profusion all summer. Easily transplanted at any stage of its growth, even when in full flower. The seed germiuates slowly requiring considerable heat, and care must be taken that the surface does not get dried out, which will surely ruin the seed. Seed often fails to germinate from this calse, especially when sown in the opeu ground.

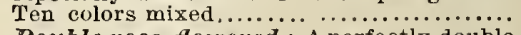
Double rose-flourerd : A nerfectly doublo variety of the above, the flowers closely resembling small roses. Everybody who sees a bed in bloom is delighted with it. About one-half of the plants from seed of first quality will usually produce double fiowers. To make a bed of all double flowers, sct plants when small 3 inches apart, and as soon as they show flower transplant tho double ones to a bed where they are to bloom, setting the plants 8 inches apart. Eight fine colors mixed, flrst quulity.......

I was pleased with the sample seeds you sent me last year, the varieties were good and the nroportlon of germinating se日d unusually large, which your modest advertisement did not lead me to expect. I want to try vour Pansies again this year. I have made a specialiy of these plants (in a small way for my owe gratificatlon), procuring the best strains obtainable, but yours last year were a revelution to me, for I did not know such colors existed in the flower. Althongh I find many choice Howers in other atrains, yours as a collection cannot be surpassed,-JordaN M. Fowher, Petrolia, Ont. 
PETUNIA: Few flowers equal the Petuuias for a hrilliant display. They are rery hardy and of the easiest culture, and their flowers are produced in profusion fron June uutil hard frosts in autumn; fine varieties mixed, Empror strain, the fiuest iu cultivation. (See list of Norelties and Specialties.)

PHLOX Drmmomolii: The inproved large-tlowered varieties of this old anumal are the most brilliaut and showy of ull galden flowers. (See list of Novelties and specialties for description and prices.)

P If $L$ o $X$ Drummondi, Drenvf, elegant Wwart, rery compact hushy plants, con pletely covered with small flowers of hrilliant eolots, including new -hades not found among the tall varietiss. Highly rec ommended for edgings to beds or for nonse culture: 10 colors mixed.

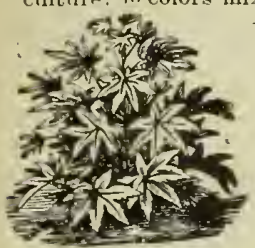

RICINUS, (Cistor bi Bean): A class of oruamental foliage plants of great beauty and quite a tropical appearance: plant 10 to 15 feet tall: leaves very large, sometimes 2 feet in diameter: fine as siugle specimeus, or in suall groups. Pla at the seed in the open ground ahout the nidRICINUS. dle of May, in this latitude, in hills 4 feet
apart and thin to one plant in each lill. apart and thin to one plant in each lill. and most distinet varieties mixed.............

S ENSITIVE FLA NT, (Mimosa pudica): A tender annual of spreading habit. with pret ty foliage; the leaves when touched, suddenly ulose and droop in a most cnrious manner.

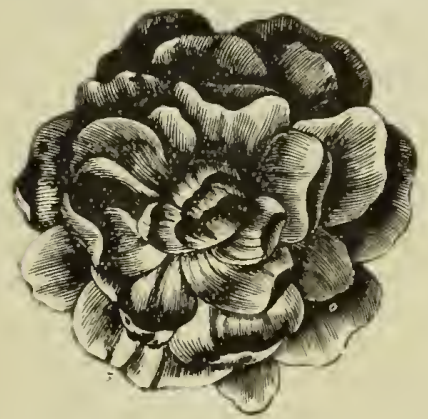

TEN WEEKS STOCK.

sTOCK Ten Wreks (Mathiola): Teu Weeks stosks or "Gilliflowers" as they are ofter called are very heautiful plauts with spleurlid spikes of double very fragrant flowers of a valiety of eolors, Seeds germinate easily either in the louse or garclen. If transplaut edl (lo so when the plants are suall, settius them in foot to eighteen inches apart, in goos rich soil:

Large $\boldsymbol{A}$, Decarf, an eatly aud free flower. ing variety; 12 colors mixed, .............. fiuest of all for garden eulture if started early. The plants grow 2 feet or more tall. of pyramidal growth and have maguificen loug spikes of rery large douhle flowers. Sow seeds in March pot off wheu small and plant out early 18 inches apart; 9 colors nixed

Giaut Perfection, pure white, the hest

nf all white stocks.....

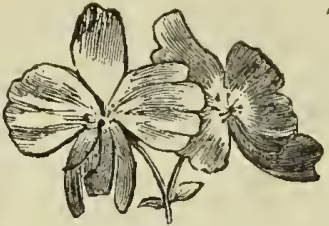

S C $\boldsymbol{H} I \mathrm{Z}-\mathrm{N}$ THUS, (But terfly Flower): Auexceedingly pretty half hardy anminal, growing ahout 2 feet in height. and literally covered with small, euriously spotted aud SCHIZANTHUS. mottled fiowers peselubling small butterflies; 10 varieties

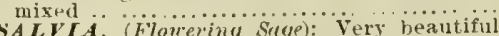
half-hardy plants, reuarkable for the brilliancy of their colors, sow seed early iu a frame. of in the house, if possible, and transplant 12 inches apat after the weather has become warm?

spleurlens, large Howers in long spikes and of the brigbtest scarlet................. patens, of the most beuutiful shade of blue kuowu in thowers. Plants may be eut back to the ground in the foll and the roots potted for the house.

sTUCK, Virgininn.(Cheiranthus maritimus): A very free bluowing lardy aunual of eas culture. with a profusion of small white, yellow and red llower's; 18 inches tall; mixed colors

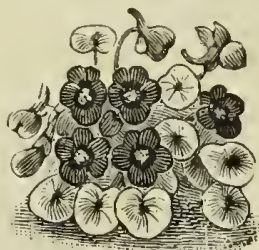

TROPEOL U IT minus, (Dwoerf Nasturtium) : $\Lambda$ splendid class of halt-harty auuuals, with fower of many shades of yellow, orange searlet and ver milliou, of $\mathrm{te}$ finels spotted. They make ver brilliant heds and flower best in soil only nod

DWARF NASTUKTIUM.

erately enriched. Plant the seeds where they are to flower. after danger from frost is past, and thiu to 10 inclues apart. Niue rari-

vine colors sepurate, sulphur spotted with maroon, orange and cernillion, yellow, rose, crimson, mavoon, scarlet, ruhy red, light red, light rellow, each color..........

Empress of India, a variety of a deeper. more hrilliaut scarlet color than any other: dark foliage.

Chaneleon, a new and elegant variety with erimson. bronze and gold variegated thowers Lady Bivd, new, golden yellow with a broud veiu of crimsou at the base of each petal...

New Golden-lenved, foliage very distiuct, light greenish yellow forming a striking con trast with the dark-leaved varieties; flowers vermillion.

VER RENA: Oue of the best and nost popu lar bedding plants in cultivation. Plants grown from seed flower better aud make stronger, bealthitr plants than fron cuttings, and are often quite fragrant. A seedling Ver hena, if giren good, rich soil, will cover a space of 3 or 4 feet in diameter, aud he a mass of Howers all through the season. Start the seeds as early as possible, and set the plants at least 18 inches apart.

hybrida, choice mixed, saved from more than a hundred varieties of all colors, ..... 1 Pure White, always true to color,........... Scarlet, finest scarlet aud bright red shades mixed: true,

striatr, various colors, fluely striped,...... Montare, a lardy perennial species with a profusion of rosy-purple, very fragrant

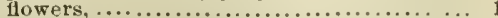

1 have had flower seeds from you for a number of years and have nerer had any trouble in always having the handsomest flowers of any one about here. and it is a great wonder to neighbors why ther cannot have as handsome Asters, Pansies and Everlastings as I have. I tell them it is because I have the best seed. I send you a elub of eight.-Mrs. E. B. Riczards, North Brookfeld, Mass. 
SCABIOSA, (Mourning Bride): This old hardy aumual deserves a place in every garden, boing very showy and of a great variety of colors, rauging from white to almost black. For cutting tir bouquets there is nothing flner. Plarits sinould lie set a foot apart. Double 'lull: 1s inches; mixed colors. Double Dwrerf: 1 foot; extra fine; mixed

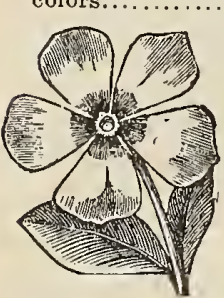

VINCA.
$\ddot{\boldsymbol{V}} \ddot{\boldsymbol{N}} \boldsymbol{C} \boldsymbol{A}: \mathrm{A}^{\mathrm{A}}$ splendid house and bedding plant with Phlox-like flowers and glossy green leaves; sow seeds early under glass: 18 inches tall. rosea, fine rose color... rosea alba, very handsome, white with rosy

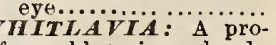
fuse blooming, hardy annual of low spreading growth, with very pretty white flowers.................... came preularia, a new species from Califoruia und one of the prettiest blue flowers ever introduced, The plant is of spreading buslyy growth, about 7 inches tall by a foot across. The flowers are very numerous, of an open campanulate form, about threefourtlis of an inch across, and of the finest satiny b!ne, of a shade very rare in flowers, rivalling the beautiful Salvia patens. It is of very easy culture and blooms in a few weeks from seeds, which may be sown either under glass or where they are to grow and thinned to 6 or 8 inches...........

ZIN NIA, Double: A magnificent half-hardy unnual, producing an abundance of flowers. which are as large and double as the Dahlia, the same flower keeping in perfection two months. Plant branching, about 2 feet in height. Set plants 18 inches apart; eight flue colors mixed?

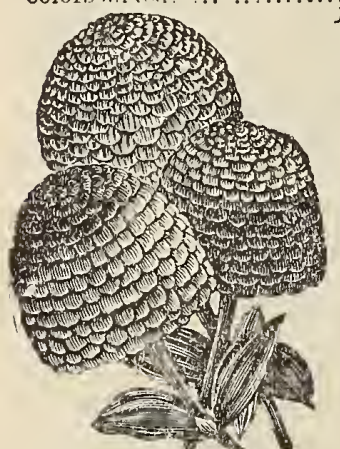

POMPON ZINNIA. ive 2 " Pompon: The flowers of $\mathrm{t} h$ is beautiful new strain are about on e-half the size of the common Zinnia and of the most perfect $f$ or m, the petals finely i mbricated, overlapping each other in the most s y mmetrical manner. The colors are very bright and varied. The plants a re of dwarf, compact growth and fairly eovered with

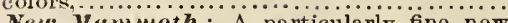
New Mummoth: A particularly fine new class of Zinnias, difering from the older ones in its unusizally lobust habit of growth and the immense size (5 to 6 inches across) of its perfectly formed very double flowers of various striking colors. The plants rise to a height of 3 to $3 x_{3}$ feet, are clothed with luxuriant foliage and bloom freely during a long period. Being of great consisteney, the flowers are uninfluenced by heat, and remain in good condition for several weeks: aight beautiful varietics

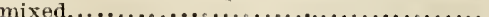

ZINNIA Hragerina $f l .-p l .$, A rery handsolne variety, with small, bright orange-yellow double flowers. Plauts dwarf and bushy............... leaved Maizt): An elegant foliage plant, three feet tall, with long gracefully drooping leaves which are regularly striped with white. It is rery effective in combination with other foliage plants. Plant in the open ground 18 inches apart, after danger from frost is past...

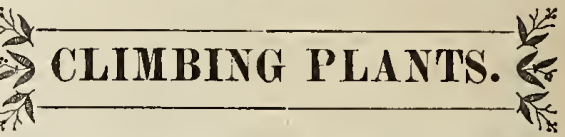

10 The annual climbers are very useful for covering arbors, verandas, fences, etc., which they will do in a very short time. Support should be furnished as soon as they begin to run.

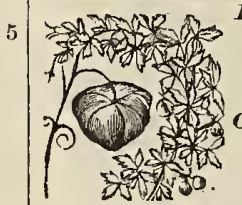

BRYONUPSIS laciniosa: Elegant foliage and small, green-striped truits, turning to red, striped with white; 10 feet................... CARDTOSP veacabum, (Balloon Vine): Very ornamental, with sin-
gular inflated, balloon-like seed capsules. Sow under BALLOON VINE. glass; 5 feet, $\dddot{\boldsymbol{O}} \dddot{\boldsymbol{C}} \boldsymbol{C} \boldsymbol{I} \boldsymbol{N} \dddot{\boldsymbol{i}}$

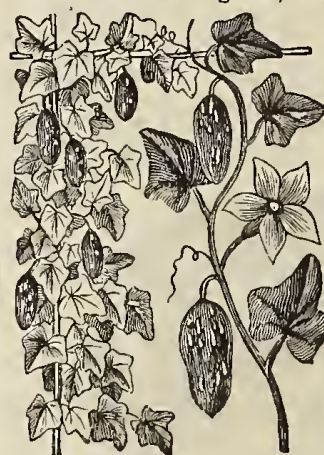

COCCINEA INDICA.

Indica: Very handsome i $\nabla$ like, s moot h, gloosy leaves, and large, white flowers, which are followed by deep s c a r l e t fruits: 8 feet... 10 CYULA NTH E$\pi A$ expllodens : \& rapidgrowing climber with pretty oval fruits. which explode with a nois when ripe...... is $\operatorname{coB} \omega A \operatorname{scren}$ deus: A beautiful half-hardy plant, growing 20 feet in a sea5

son; flowers, large, purple, bell-shape. Start the seeds as early as possible in the house, and set them edgewise, and do not water unless the earth gets very dry, otherwise they

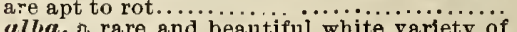
the above and beautiful white varety of CONVOZVÜUS major, (Morning Glory) : A well-known and very popular hardy climber of rapid growth, with splendid large flowers 10 of a variety of colors. All colors mixed....

ECHINOCISTIS lobatn: A very strong, rapid-growing, climber, with iry-like leaves and large clusters of whitish flowers in profusion all summer. Seed must be planted in the fall. or well soaked in warm water........ IPOAT $\boldsymbol{C} A$ Quamoclit, (Cypress Vine) : Ele. gant foliage and small, bright scarlet and white flowers. Soak the seed well in warm water and sow under glass early; mixed

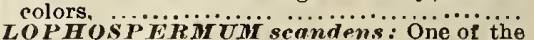
finest of climbing plants, with bell-shaped rosy-carmine flowers; 6 feet; sow in boxes...

I tried twice to get some Pansy plants and once Violas from your soeds, without getting a single plant. I deemed the fault to be in me and not in the sced. so determined to send to you for more and try again, carefully followine directions and avoiding what I deemed to be the cause of previous failure. I sowed two prekrts of Pansy, and 11/2 of Violas, and got about 200 Pansy and 100 Viola plants. Doubtless many people have just such luck as I had at flrst, and forever blame the seedsman, when their own ignorance or carleesness should be charged with the result.-CHAS, A. BANisTER, Indian Orchard, Mass. 


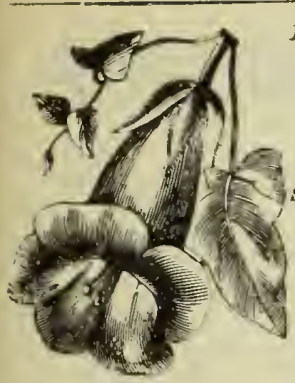

MAURANDYA.
M A C R I N I A Burelugande: A beautiful hardy climber: with bell shaped Howers and neat, a bull ant fuliage: 6 fcet ; wixed colors..... 川EET PEA : A w $\rightarrow 11-\mathrm{k} n \circ \mathrm{w} u$ and very fragrant hardy snnual. Plant in rows or clumps 4 inches deep, as early in the spring as possible, and furnish support as soon as up. $12 \mathrm{col}$ ors, nixed, per lb.,

$\$ 1.00$, per oz.. 10 eents, paekets

Ticelve colors srparate..- White, pink snd white, blush, purple, dark red, srarlet invincible, purple striped. black, light blue and purple, blue-edged, scariet striped white, nink. ench color, per $32 . .15$ ets; pkt Collertion of $1 \%$ colors, one packet of each, i5 cents.

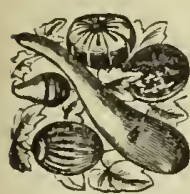

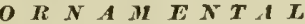
$G$ G $U \boldsymbol{R} D \mathrm{~S}$ : Rapid-growing clinibers, prurucing some of the most elegantly colored and singularly formed of all fruits. Plant in rather poor soil. Or. ange. Lemon, Apple, Pearformed. and nany other

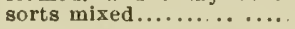

OINAMENTAL CUCUMBERS: These, although called encumbers, bear no resem. blunce to the garden cur'unber, but are very useful elimbers with highly ornament al fruits of various enrious forms and colors. Plant in the open ground after danger from frost is past. Balsam Pear, Balsun Apple, Guoseberry formed, Serpent-fruited, and saveral other sorts, mixed,

TROPEOL, CM mnjus: (Tasturtium) One of the ver'y liest and eas est grown of the elimbers, suceeeding in any garden soil. The flowers are of many shades of yellow and searlet, striped aud spotted. 11 colors mixed...

Elenen rolors separnfe,-ectimson, searlet, orauge, liruwnish lilac, chocolate, yellow, gearlet-striped, light yellow, straw calor sputted, purple riolet, maroon.-each color perpgrinum (Canrry-bird. Flower): Bears a pofusion of small, bright yellow flowers; rery flne; 15 feet.

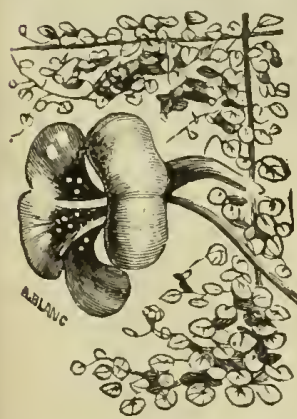

Lolbbianmane beautiful species with flowers resembling the eommon ' $\mathrm{T}$. $m a j u s, b u t$ they are more cup-shaped and of $m \circ r$ brilliant $\mathrm{c}$ (1) ors; 8 feet mixed colnors.

THINRERGTA olnta: an ele gant elimber with a profusion of yellow, white and orange flowers with d a r k centers. Sieeds Should be sown in boxes in TROPCELUM LOBBIAXUM. Warm place; feet : 6 varicties mixed,
VICIA Germoli: A pretty and very hardy plant, bearing mumerous pia shaped violetpurple flowers, in clnsters all summer; 6 feet,

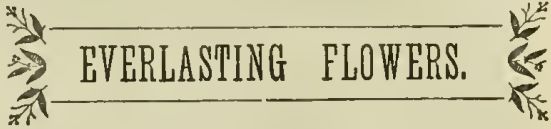

The Everlastiug Flowers are a very valuable and beautiful class, keeping their natnral form and eolor for niauy years. The flowers should be eut when in the bnd, $\mathrm{or}^{-}$as soon as they begin to open, aud hung up iu small 1)unehes so that the stems will dry straight. They may then be worked up into small bouquets, wreaths, ba-kets, ete., and make beautiful ornaments t.r the parlor. Plauts of all the varieties may be set about ten inehes apart.

ACROCLINIUAK roseun: one of the most beautiful of the Everlastings; bright rose color and whitı: mixed eolors...........

New Couble, a splendid double variety of the above

A MMOBIUM grandifirmon "This is a valuable addition to the Everlasting finwers, being double, pure white and twiee the size of the old varlety.

GOMJRREXA yobosa: The best kilown of Everlasting Flowers. Should not be pieked until the flowers are fully grown. Before sowing soak the seeds 48 honrs in warm water; 5 colors mixed..

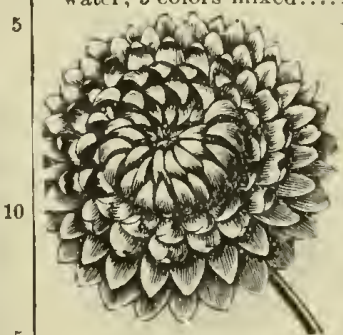

HELICHRYSUM $\ddot{\mu} \ddot{\boldsymbol{i}} \ddot{\boldsymbol{i}} \boldsymbol{i} \boldsymbol{i} \ddot{\mathrm{r}}$ ( monstrosume: One of the very best and nust shiwy of the Evel lastings: flo we r v very liarge and double and of minly feet; mixe d feet; mixed

RIOD.A NTIIE:

Very elegant and delicate rose colored, white and maculated flowers; nixed colors

HELIPTERUM Sanfordi: A very choice variety, cach plant, hearing a good many large elusters of small, rich goldeu-yellow flowers. XERA NTH E.Y TM: Purple and whito doublo bell shaped flowers; mixwd t
10

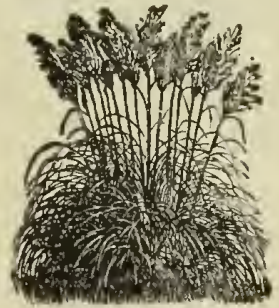

ERIANTHUS.

ORNAUTHAI G I A S S I S : These art $\nabla$ ex $y$ usteful f, l' workillg up with tho Everlasting filowers. Sow in the open grominl early in the spring. They shnula be cut when in blonm Tie up in suall bunches, and dry iu the shitle. A great varet $\mathrm{j}$

ERIA NTIU

Rovennas: A gicantic perenuial orass, growing 10 or 12 fert tall with clegant plumes of flowers a foot in lengtl. It is very fine when grown as siugle specinens for lawns. Not quite hardy north of New York, but plants may be easily kept over in a box of moist earth in any cellar. Blonms second

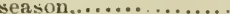

Enclosed find annthar order for seeds. Those receired from you in several previous ordars are all dring splendidly, and as many of them wore varieties difficult to manage, 1 am more than plassed with my success, and think it is largely due to the superiority of your seeds. Thanks for your liberality in the matter of extras which you sent with mp prior orders. Your prices not only average lower than any establishment I know of, but you a re also more liberal than any with whom I have dealt. - EuCL1D SANDER, Stockdale Farm, Iowa City, Iowa. 


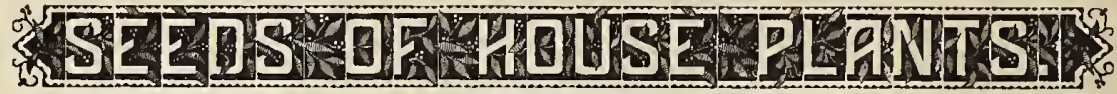

There is a good deal of pleasure in growing house plants from seeds, and very often as many plants can be grown from a packet of seeds as would cost several dollars if purchased from a green-house. Mauy of the varieties germinate as easily and quickly as the commou annuals if properly treated. Fill shallow boxes (cigar boxes are just the things) nearly full with very fine, nice garden soil of a sandy nature, and press it down smooth and hard; make drills an inch apart by pressing the straight edge of a thick pane of glass into the soil to the depth of a sixteenth or an eighth of an inch, according to the size of the seeds; sow the seeds and fill up the drills with fine sandy soil that has been sifted through a fine sieve; press down the soil quite hard over the seeds aud water earefully with a flne spray, so as not to wash the soil from the seeds; cover each box with a pane of glass and set them in a good warm place. A mantel shelf behind a stove is a good place for those who do not have a green-house. Take particular care to keep the soil just moist, so that it does not look dry, until the seeds germinate. As soon as the plants begin to come up, give plenty of air by partially or wholly removing the glass, and move the boxes at once to a warm, sunny window.

The above directions apply to seeds of medium size like Ciueraria and Primrose. Very fine seeds like Calceolaria, Begonia, Achimenes, Gesneria, Gloxinia and Tydæa, should be scattered. broadcast, ou the surface, which has been made firm and perfectly smooth with a piece of board; then sift a little earth over them through a fine sieve to a depth equal to the thickness of a thick sheet of paper, - just enough to cover them from sight. The best way to water the seeds and young plants without injury to them, is to set the box ill a pan containing an inch or two of water and allow it to soak up from below, removing them from the pan as soon as the moisture begille to appear at the surface. Before sowing the seeds make a number of small holes in the boxes. Do not wet the leaves or stems of small plants if it call be avoided as it is liable to cause them to "damp off" or decay. The seeds of Geranium, Gyclamen, and Smilax are very hard and slow of germination. Cover these a quarter to half inch deep, and they must be kept quite moist and warm till they germinate, which will be in 4 to 8 weeks; and they should be sown in boxes by themselves and not mixed with other seeds. After house plants have made a little growth, and as soon as large enough to haudle, pot off singly in small pots and finally shift to 4,5 or 6 inch ones, which are the right sizes for flowering. They should be kept growing vigorously in good rich soil during the summer, to obtain an abundance of nice flowers in winter.

The seeds I offer were saved from the most celebrated prize esllections in the world, have been carefully tested, and will germinate freely if properly treated.

\section{$C A C E O L A R I A$}

lybrida: One of the grandest of house plants, bearing a mass of curious pocket-like Howers in April and May. Flowers of varions shades of yellow and elegantly spotted a. 11 d blotened with crimson and maroon. Sow seeds in August. Very choice seeds from a celebrated vrize collection

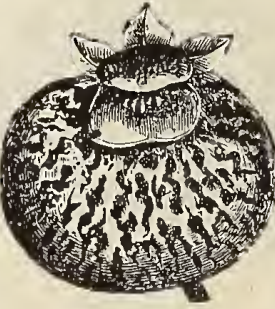

CALCEOLARIA.

CIIA NTH Ü Dampievi, (Glory Pea): А maguificent trailing plant with large clusters of pea-shaped scarlet flowers, each flower 3 to 4 inches long, with a large black spot in the center. Start the seeds early in small pots, kceping them very moist and warm till they germinate and plant out in the open ground in June, without disturbing the roots, in warm, sandy soil. Packet of 15 seeds, ....
CINERAIIA

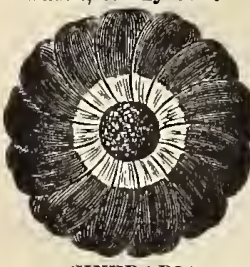

CINERARIA GRANDIFLORA. ( $\frac{1}{2}$ natural size.) large tlowers of the richest colors, the plants covered with a mass of bloom; choicost mixed from Benary's colebrated collection.

COLEUS: The most popular of ail foliage plants, the leaves variegated with many shades of red, yellow, maroon, ete : choicest mixcd, from a large collection of named $\mathrm{va-}$ rieties.....................................
25

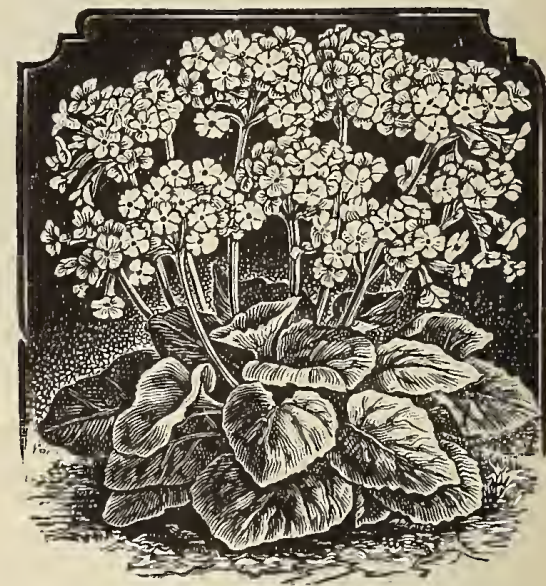

PRIMULA OBCONICA.

PRIMULA obeonica, (Everblooming Primrose): A new species of Primrose and one of the very best house plauts I have ever seen. The flowers are an inch across, in large clusters on long stems and a plant is never without flowers, a good plant often having twenty or thirty clusters on at a time. The flowers are white, sometimes tinged with lilac and have the true Primrose fragrance. Plants from seed sown in early spring will begin to fiower in summer and continue in full bloom throughout the year never failing to produce their lovely flowers even during the dullest winter months. This is one of the things that cannot be too highly praised and is sure to please everybody $. . . \ldots \ldots \ldots \ldots \ldots \ldots \ldots, 20$

The Mammoth French Pansies excelled in size and beauty of color anything I have seen, many of them measuring three inches across the blossom; and they with our Asters, Poppies and Everlastings, were admired by all.-MrS. W. M. Sн1т, Warren, Mass. 


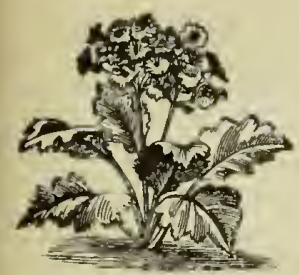

CHINESE PRIMHOSF
CHINESEIRIMISOSE (Pimula vinensis): The Chinese Primrose is one of the bost satisfact ory of house plants. The flowers are white and many shades of red. some flnely striped and spot. ted. Sow SeAds from April to July and they will blo om profusely the following winter and spling. Corferseeds an eiglith of an inch with flne, light soil, and keep the earth quite moist and at about 60 degrees. Fine nixed, packet of about 40 speds

Choiervi mixpol from the finest collections

of fringed, and large fowering varieties in Europe: packet of ahont 40 seeds

CIIIYSANTIIEMUM Indicum: These popular autunu-blooming plants are as easily raised from seeds as Asters, but only a small percentage of plants from seed will be as double as the hest named varieties, even with the best of seed. They bloom the first year if sown in Fobruary ol March. Sow alld treat them like Aster's, potting them up for the house in Angust. Choicest mixed, from a large collection, including all the newest and finest varieties of Cbinese, Japanese and Pompon.

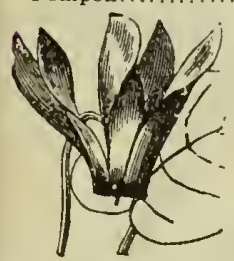

CTCLAMEN Persicum: splendid bulb. ous plants, with Orehidlike delic ately colored fowers in abundance all wiuter. The leaves are very prettily variegated and veined, and it is sure to delight all wbo grow it. The seeds require from 6 to 8 weeks to genminat , but every seed ls sure to gerniCYCLAMEN. nate Purplc, rose, white, etc., mixed colors … .............. large flowers of various rich colors.

GERANYUM: These well-known bedding and house plants are easily grow n from seed, which germinates unevenly hut quite surely. Soak the seeds for 12 hours before sou ing, and keep it moist and warm until it germinates. Zourule, choicest mixed, from a large collection of uanied varietles.

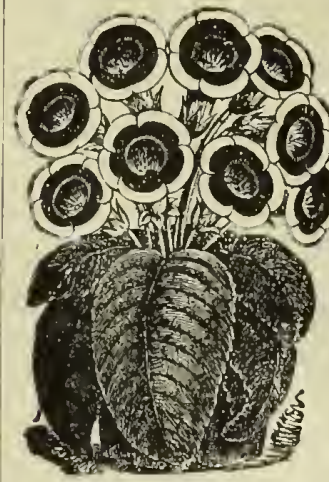

GLOTINIA grandiflora : This is a su pe $\mathbf{r}$ b slummer blooming bu 1 hous plant,pro dncing magnificunt largh bell formed flowers of peculiar rich uess of texture an d coloring. They are white and all shades of purple nind red, from rose to crimsoll, some with a bo r d \& $r$ or another color, others elegant ly stained and spotted. Thire is a peen $1 \mathrm{i}$ ar GLOXINIA. GRANDIFLORA. richness about them which attracts the admiration of every one. They are very easily glowu in liglit rich soil. If seeds are sowll in Jaunary they bloom the first year, but if sown ut any time in spring will make fine bulbs for the second year. The bulbs can be preserved over winter in partially dry dirt ia any warm room or eeller. They do best in a warm, sbads window, but often do well bedded out in a shady place. When grown in the house care should be taken not to wet the leaves. Choicest mixed seed, including the newest French spotted varieties........

rubers of Gloxinias, in mixed colors only, 25 ets each, 3 for 60 ets.

HELIUTKOFE: These are easily raised fiom seeds and make strong, healthy plants :

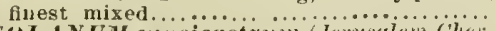

SULAN UXI cupsicastrum, Jerusalem cher ry): A fine old honse plaut, bearing bright red berries the size of cherries.

15 SHILAX, (M. Aspuragoirles: An elegant clinhing plant, with glossy, green leaves, soak seed in warm water for 48 bours before sowing

TYIEA hybrilla: Elegant bulbous plants, resembling the Gloxinia and requiring simi. lar treatment ; choicest mixed

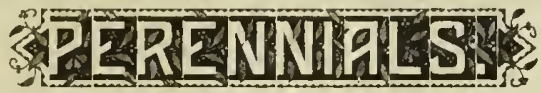

The rarieties under this head mostly flower in the spling and summer of the second jear, from seed, and wost of them continue in perfection for many years. S.eds may be sown at any time in the spriug; and as they mostly require two or three weeks to germiuate, particular care should be taken to keep the gromud entirely shaded from the sun and well watered until they come up. Set plants a foot apart in any unused corner of the garden the first year, and transplant to the beds where they are to blomn. early in tle fall or spring. It is well to protect them during the winter with a slight covering of leaves, striw, or evergreen boughs.

AQUILEGIA, (Columbine): An old, bardy pereunial, prodicing fine flowers of a great many colors: 30 varieties mixed..

caeruler. Howers 2 or 3 inches in wilth and as much or more iu length: skv blue with white centers: 3 feet tall. This and the following are finest of all the Aquilegias. .

clerysurtha, like the ahove except in color, which is a heautiful canary yellow; remains in bloom a loug time..
ALYSSUM saxutile compactum (Gohl Ditst): A eliarmiug little plant with goldeu

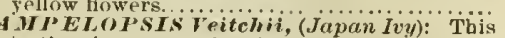
is the vine so popular for covering the walls of brick and stone huildings, elinging close to the walls and climbing to a great beight. Seeds require about a month to germinate, and had best be sown in the fall, or in a hox and placed where they will freeze, which will

help germination.........................

Many thanks for the extra packet of Chinese Primrose seeds you sent me last year. 'lliey ale truly magnifieent aud have been in hloom orer four months, and all $\mathrm{my}$ friends come to see them.Mrs. líndal, Sydncy, Cape Breton, Nova Scotia.

I want to tell you of onr success in raising Gloxiuias from your speds. I have 29 nice plants, 13 of thron in bloom and 12 different varieties. All say they äre a wooderfnl display for liomse conlture.(iEo. H. RoBERTs, Medfield, Mass.

All the seeds 1 have had from Pansy Park have been excelleut. From the packet of Gloxinias I bave raised over siaty good phents, which will hloom this sumuter. M. E. STONE, Worcester, Mass. 
CAMPANULA : These are among the best of the perennials, with large bell-shaped flowers, white, rose, blue, etc.

Mndium, (Canterberry Bell), double and single mixed; eight colors.................... calycuntheme, (Cup and saicer Canter-

bur'y bells), an elegant variety with the ca-

lyx colored like the corolla,.................

CAliN ITION, (Dianthus caryophyllus): The most magnificent of the Pink family, with ors; choicest mixed, German seed, from named flowers only.

CHRYSANTHEIYUA inodorum $\boldsymbol{h} .-p \ddot{i}$ : A beautiful species of hardy Chrysanthemum with elegant feathery foliage, bearing a profusion of double pure white flowers, $1 \frac{1}{2}$ inches across, from Jume to August,.................

DYANTHUS plumarius, the old original pragraut Glove Pink..... fine double variety of

DELPHINIUM, (Perenniai Larkspur): For a mass of blue there is nothing that will equal in riehness and brillianey the Perennial Larkspur; finest mixed....................... Dusble, magnificent and very showy, from fluest named varieties,

מ I I ITAIIS, (Foxglove): A very showy jinnt with long spikes of flowers,

Iory's New Spotted, elegantly spotted flower's of several shades, $\ldots \ldots \ldots \ldots \ldots \ldots \ldots \ldots$.

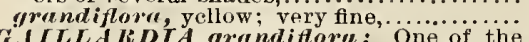
vily fiuest perennials, thowering for several months. The fowers are two inches or more across, yellow with bands of maroon,

GLADIOLUS : The Gladiolus is easily raised from seed, flowering the third year and secdings are always of a great variety of colors. The bulbs should be taken up in the fall and preserved like Dahlias; choicest mixed...

HESPERS matromalis, (Sweet Rocket): large chusters of sweet-scented white and

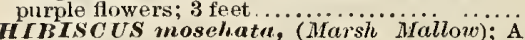
fhe nerennial with large rose colored and whitelluwers, five inches across; mixed colors

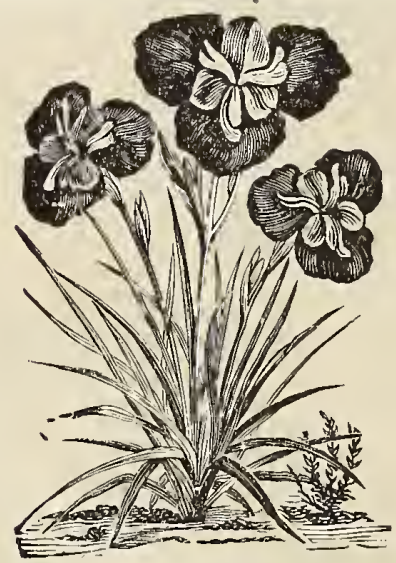

JAPAN IRIS.

IRIS Kameleri, (Japan Iris): This new lris, from Japan, is the most magnificent of all the Iris fanily. The flowers are from 5 to 8 inches in diameter, white and many shades of rich blue and purple, often blotehed and luced with rollow and white. Easily grown from seeds, which germinate in 3 to 4 weeks; mixed colors. . .
IBERIS sempervirens, (Perennial Candytuft): Very desirable perenuial, bearing clusters of white flowers in May and June........ spikes of searlet and yellow flowers; 3 feet tall; mixed colors........................ LINUM perenne, (Perennial Flax): Very graceful and handsome; blue, yellow, white, rose, etc., mixed..........................

LUNARIA biennis, (Honesty): An old plant with purple flowers and curious silvery seed pods; very useful for winter bouquets; 2 feet,

LUPINUS, (Lupins): Very showy plants, 2 to 8 feet tall, with large spikes of pea-shaped flowers of nituy sliades of blue, yellow and white; $1 u$ var.cties wixed.................. 10

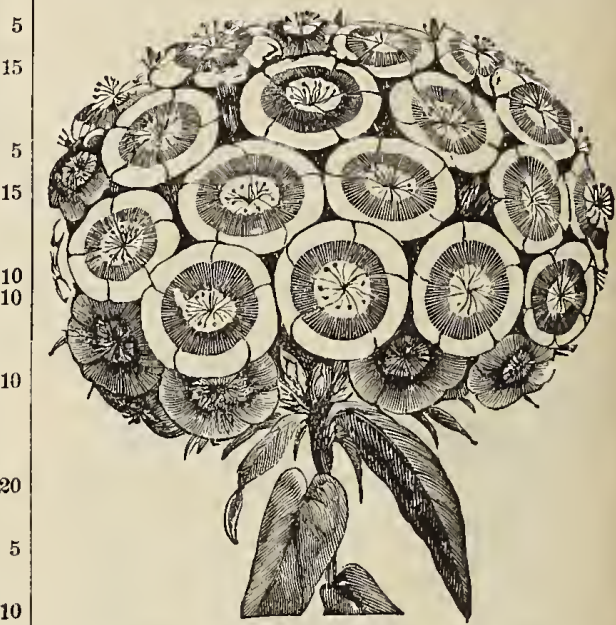

IMPROVED PRIZE SWEET WILLIAM.

(1/4 natural size.)

SWEET WILLIAM, (Dianthus barbatus): The Sweet William is an old and well-known flower, and has been much improved of late years, the trusses and flowers beiug larger and of a greater variety of rieh and beautiful colors. My strains are the finest in the country, and have received First Prizes when exhibited at the shows of the Massachusetts Horticultural Society.

Carter's Auricula-eyed, large white centers, bordered with various shades of richest red, crimson, maroon, etc.; extra choice, 10

Double White, new.................... 10

Double varieties mixed, a very fine strain, 10 Dunnett's Dark Crimson, a splendid sort of the deepest crimson or maroun, almost black.... ...........................

Dunnett's Darli Crimson. Double, splendid.................................... 10

Hunt's Perfection, very rich colors bordered and edged with white................ Hunt's Perfection, Doubie, beautiful double varieties of the last.............. 15 Harlequin, a new variety with elegantly mottled and spotted flowers..............

Dwarf, a dwart compact plant, only 6 inches tall; very fine; mixed colors................ 10 Dwarf, double, a double variety of the last, 15 All the varietics in spleudid mixture, making the finest strain of Sweet Wil-

liams ever offered........................ 10

1 wish to tell you how magnificent my Pansies have been this summer. I never had eaything like them in all the years I have raised them. My bed contaius 110 plauts, and such a varioty in colorss'aremly two alike. They have been beautiful beyoud description and a constant sonrce of pleasure to us. T'be Phlox, China and Japan Pinks, Double Portulaca.Antirrbinum and Asters have been in blossom ull aummer. Every seed canc up well. We counted sixty blossoms on a Nicotiaua plaut one day. Wiask C. Shuthon, New Haven, Conn. 
LATHFRUS latifolius, (Perennial Pea): A fine perennial clinber, with large clusters of red and white flowers.

PAPAVER, (Perennial Poppy): Very showy scarlet and orange and yellow flowers, 4 inches across with large black blotehes... ....

PRIMULA, (Polyanthus or Primrose): A very interesting and beautiful class of springblooming flowers. Seeds regnire from 4 to 6 weeks to germinate, and must be sown under glass.

elatior, choicest mixed from named flowers, Duplex, spleudid double varieties.

Gold-laced, yellow-edged flowers; very fine,

PRIMULA rulgaris: This is the Yellow Primrose of England, blooming in spring and very pretty. Seeds require 2 months to germinate

WALLFLOWER, (Cheiranthus Cheiri): A Fery beautiful half-hardy perennial witl spikes of fragrant flowers resembling the Ten Weeks Stock. They require the protection of a cold-frame or pit during winter, where the winters are severe: 1 to 2 feet tall; choicest double mixed, a great rariety ...............

PERENNIAL PHLOX: The Perennial Phlox is the best hardy perennial we have, and is especially fine for city gardens, as it does well in partial slade. The seeds unust be sown in the fall soou after they ripen or they will not germiuate. Sow in the open ground a lialf inch deep late in the fall and it will germinate freely in the spring and Hower the same year. Fresh seed saved from about 20 ehoice sorts. sent in October and Norember only.

PLATYCODON grenditora: A grand showy plant 4 feet tall, with large neat blue and white flower's in abundauce from June to September; mixed colors, ...

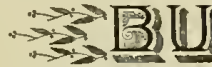

CHINESE FAM, or Cinnamon Vine, (Dioscorea batatas): A beautiful herbaceous, ornamental vine of remarkably rapid growth, climbing from 15 to 30 feet in a season. The leaves are glossy green, veined with purple, and are never touched by iusects. The flowers are small, white, in clusters, and emit a peculiar, cinnamon-like odor, so strongly as to fll the air around in the evening. The roots or tubers, which are edible, increase in size from year to year, and grow to a weight of several pounds each, and when once started, will last a lifetime in the gronnd. Plant roots three inches deep in any good soil. It is well to cover the roots a little with some leaves or straw the flrst winter, but after that they are perfectly hardy in any part of America. The roots can be planted whole or divided in pieces, and each piece will grow. One year old roots. $20 \mathrm{cts}$. eacn; four for 50 cts.: twelve for $\$ 1.00$. Ready early in April.

GLADIOLI: The Gladiolus is the best and most popular of what are called Snmmer Bulbs. Its tall spikes of large flowers, which are almost every shade of color, spotted, blotched and striped in the most beautiful manner, ale truly gorgeous. The bulbs may be planted six inches apart, in any ordinary garden soil, in April, May and Jnne, and covered from 3 to 5 inches deep, according to size, and they will al ways give a good account of themselves. The Gladiolus blooms in about three months from planting, and by planting them at intervals of two weeks they may be had in bloom from July to October.

GLADIOLI, splendid mixed vurieties, including many fine seedings equal to the best named varieties. They are nice flowering bulbs and always give the best satisfaction, making a splendid displas for a little money. Per dozen, 35 cts; per half dozen, 20 cts.; per hundred, $\$ 2.50$; per thousand, $\$ 20.00$.

GLADTOLI, numed varieties; I have a large collection of choice named varieties; prices, from $15 \mathrm{cts}$, to $\$ 3.00 \mathrm{each}$.
F'FRETHRUMI roseum, (Insect Pouder Plant): A fire, hardy plant, with large Daisylike flowers of different shades of red. The insect powder of commerce is the dried and powdered petals of the flowers: mixed colors, Parthenium H.-pl,, (Double Feverfew)... parthenifolium a urmm, (Golden Feather)

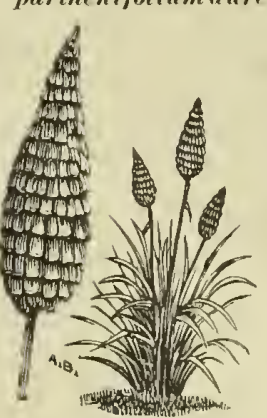

TRITOMA TRITOMA grandifora, (Red-hot Poker 'Plant): A very handsome and showy hardy herbaceous plant, with tall spikes of bright red and orange flowers. North of New York it is best to take ap the plants with a little earth and place in the cellar, where they will keep safely till spring.

PUNTSTE MON: One of the best of the perennials, the Howers in long spikes of very bright scarlet, rose, GRANDIFLORA. yellow, ete.; mixed

color:

POTENTILLA: These are very popular in England aud should be grown more in this country. The flowers are of rery brilliant and raried colors and freely produced for a long time; 1 fuot; double nixed, from a YUCC A filamentosi... A grand hardy plant.

with a tropical aspect, bearing tall spikes of lily-like white flowers..

10 VERONICA: Showy spikes of blue flowers,

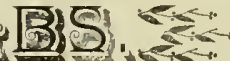

LILIES: 1 select the following from a largo number of varieties as the best and easiest to cultivate, and am sure they will give satisfaction to all. Plant 4 inches deep, and cover with a few inches of leaves during winter. Rearly in April.

LILIUM a uratum, the queen of lilies, with flowers 8 to 12 inches across, pure white, spot. ed with crimsen, with a golden band throngh the center of each petal; very rragrant. each.

lancifolium rubrum, white, shaded with rose, spotted red; one of the very best ;

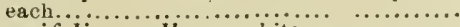

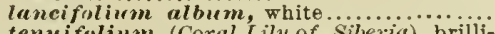
tenuifolinm. (Coral Lily of Siberia), brilli-

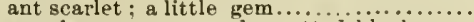
superbum, orange red. spotted black......

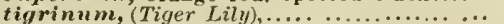
tigrimam $t . p l .$, (Double Tiger lily)... . . 20 Wrillacei, orange, sputted black,........ 15 Leichtini, canary yellow, spotted crimson, 75 Colcretina of Liles: For $\$ 1.00$ I will send fire choice Lilies, - Aunf nm, Lancifolium Album. Lancifolium Rubrum. Tigrinum fl. $\boldsymbol{l} l$, and Frallacei, provided thes are oldered before April 1.

TIF $\boldsymbol{R} \boldsymbol{I} \boldsymbol{I A}$, a beautiful genus of half-hardy bulbs, with cnitious and show shell-like flowers, 4 inches across. Culture like Gladioli. conchiflora, yellow and orange, spotted black : $10 \mathrm{cts}$ each, three for $25 \mathrm{cts}$

pavonire, led, spotted crimson ; $10 \mathrm{cts}$, three for $25 \mathrm{cts}$.

alba, white, with brown spots, each.

TUBEIOSE, Pearl: The Tuberose bears spikes of pure white, wax-like, double flowers. Plant in boxes in the lonse, and remore to the garden when the weather has become warm. or they may be flowered in pots orboxes. Pearl is a new dwarf variety and much better than the old sort being of low growth, with larger flowers: $10 \mathrm{cts}$, each, three for $25 \mathrm{cts}$. per dozen, 15 cts.

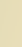




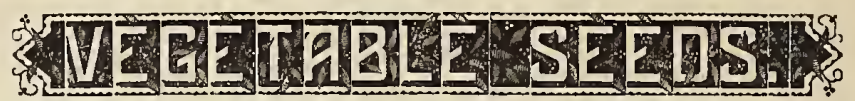

I do not offer a long list of vareties, but only such as experience has shown to be the best, the cream of a large number of old and new varieties. I design to have my regetable seeds as reliable as my flower seeds, and all who favor me with their orders may depend on receiving the very best in every respect. During the past fow years a great amount of rubbish has been offered in the way of socalled "novelties" in vegetables. I have tested all of these "novelties," and lind nine-tenths of them either old varieties with new names or not as good as the old sorts. Such as I find to be really new and better than older varieties I add to my list as fast as careful tests prove them to be desirable.

All varieties not otherwise priced are $10 \mathrm{cts}$. $p \mathrm{cr}, 0 z$. No halfounces sold unless priced by the ha'f ounce. All seeds sent by mail or cxpress, prepaid, at prices quoled.

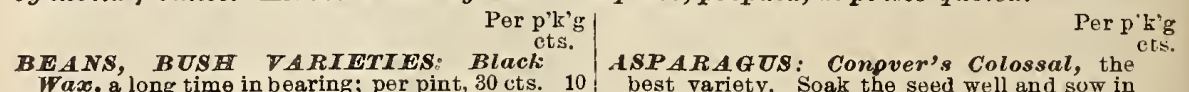

Wax, a long time in bearing; per pint, $30 \mathrm{cts}$. 10 best variety. Soak the seed well and sow in

Gold cre Wax, very tender and fine; piut, $\mid$ drills two inches de日p. 75 ets. lb.; 25 ets. $1 / 4$

30 cts........................................

liest and best for shelling, either green or

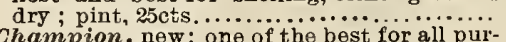

poses; pint, 30 cts......................

poses; pint, 30 cts......................

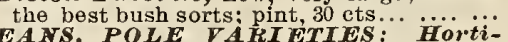

cultural or spcckled Cranberry, old

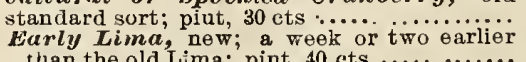

Challenger Irima, now and extra fine; very productive, the beans growing elosely to-

gether in the pods; pint, $40 \mathrm{cts} . . . . . . . . . .$.

bush Lima Bean, growing 18 inches tall, bearing large erops, and two weeks earlier than the climbing Limas. The beans are of the size of the Sieva, and are of that delicions quality that has made the South-

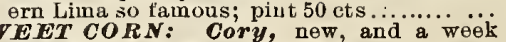

8 WEET CORN: Cory, new, and a week

Marblehead, follows the Cory in earliness;

pint, 25 ets.................................

pint, 25 ets .............................

early sort; pint, 25 cts.....................

Black Mexican, follows Crosby iu matur-

Potter's Excelsior, or Squantum, new, andth $\theta$ sweetest and tenderest of all varieties; a little later than Mexican; large ears; pint, 25 ets.

Evergreen, old stand ard sort; pint, 25 cts.,

Mammoth sugar, latest and largest of all; pint, 30 ets.................................... sorts at one time a complete succession can be had from earliest to latest.

PEAS: MrcLean's. Iittle Gem, the earliest and best of early wrinkled sorts; 2 feet tall; pint, 25 cts....................... $\boldsymbol{A}$ bundance, a new and remarkably productive secoud early sort, first quality; 2 feet; pint, $25 \mathrm{cts}$..

Champion of Enyland, best of all forlate

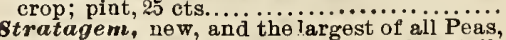
with 7 to 9 peas in each pod; 2 feet tall; first quality; pint, $40 \mathrm{cts} . . . . . . . \ldots \ldots \ldots$.

POP CORN:' New tolden, very large and

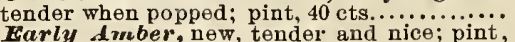
$40 \mathrm{cts}$.

BEDT: Eyptian Biood Turnip,

early. 75 cts.lb.; 25 ets. $1 / 4$ lb.... ..........

Eclipse, new; very early, round and smooth, fine grained and sweet. 90 cts. lb.; 30 cts. $1 / 4 \mathrm{lb}$; $10 \mathrm{cts}, \mathrm{oz} . .$.

Farly Bassano, very early, tender and sweetest of all early sorts. 75 ets. lb.; 25 cts. $1 / 4$ lb....................................

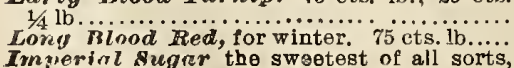
Imperinl Augne the swaetest of all sorts,

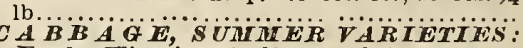
Early Winningstudt, one of the most reliable for heading. $\$ 1.85 \mathrm{lb}$; 6 , cts. $1 / 4 \mathrm{lb}$;

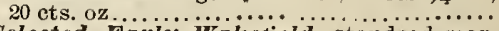
Selected Eariy Wakefield. staudard market variety. $\$ 3.60 \mathrm{lb}$; $\$ 1.001 / 4 \mathrm{lb} . ; 30 \mathrm{cts}$.

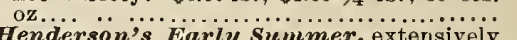
grown for market. $\$ 3.60 \mathrm{lb} . ; \$ 1.00 \mathrm{1} / 4 \mathrm{lb}$.; 30

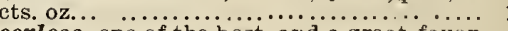

Peerless, one of the best, and a great favorite with Boston market gardeners. \$3.60 lb.; $\$ 1.001 / 4$ lb.; 30 ets. oz...... ...........

WINTER VARIETIES: Warren's sione Mason, very popular among Boston market gardeners, nearly every plant being sure to head. $\$ 3.60 \mathrm{lb}$.; $\$ 1.001 / 4 \mathrm{lb}$; $30 \mathrm{cts}$. oz ... $\ldots$; Marblehead Mammoth, the largest of all;
has been grown to weigh 60 lbs. each. $\$ 3.50$ lb,; $\$ 1.001 / 4$ lb.; 30 ets. oz.................

Fottler's Brunswick, popuiar for market, $\$ 2.35$ lb.; 70 ets. $1 / 4$ lb.; 2.5 ets. oz... ........ Premium Flat Dutch, old standard sort. $\$ 2.00$ lb.; 60 cts. $1 / 4$ lb.; 20 ets. oz........... Late Blood Red, tor pickling. 20 cts. oz... Mammoth Rock Red, new, and the laritst and finest of all red sorts, averuging $1: \mathrm{lbs}$.

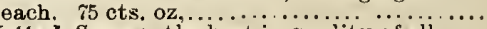

Netted Savoy, the best in quality of all.....

CAULIFLO WER: Henderson's Larly snowball (True), the best and most reliable variety, nearly every plant producing a good head. $\$ 14.00 \mathrm{t} / 4 \mathrm{lb} . ; \$ 4.00 \mathrm{oz}$.; $\$ 1.00 \mathrm{1} / 4 \mathrm{oz}$.

CARROT: Early Oxheart, one of the best.

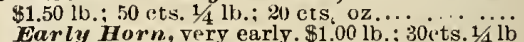
Half-long Red Stump-rooted, the best second-early sort. $\$ 1.00 \mathrm{lb}$; $30 \mathrm{cts} .1 / 4 \mathrm{lb} . .$.

Danvers Orange, an implorement on the old Long Orange. $\$ 100 \mathrm{lb}$; $30 \mathrm{ets} .1 / 4 \mathrm{lb}$...

CEIERY: Boston Markit, one of the best.

$\$ 260 \mathrm{lb}$; $75 \mathrm{cts}, 1 / 4 \mathrm{lb}$; $25 \mathrm{cts}, \mathrm{oz} . \ldots \ldots \ldots \ldots$

White I'lume, new, crisy solid and fine flavor, and easiest of all to grow. $40 \mathrm{ets}$. oz. Major Clark's Pink, of better flavor than the white sorts, criso and solid. $30 \mathrm{cts}, \mathrm{oz}$. CITRON, Californian, very large. 15

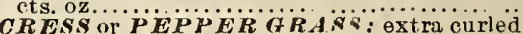
CUCUMBER: Warly Russian, the earliest. $\$ 1.00 \mathrm{lb} . ; 30 \mathrm{ets} .1 / 4 \mathrm{lb} \ldots \ldots \ldots \ldots \ldots \ldots \ldots \ldots$ Eurly Cluster, very early. $\$ 1.001 \mathrm{~b}, ; 30 \mathrm{cts}$.

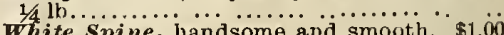

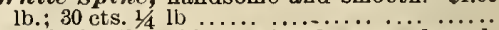
Treiby's Hybrid, very handsome and good. $\$ 1.10 \mathrm{lb}$.: $30 \mathrm{cts} .1 / 4 \mathrm{lb}$............

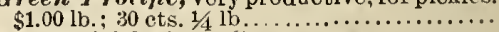
Nichols; Medium sreen, new, very productive, and one of the very best for table use or pickles. $\$ 1.00 \mathrm{lb} . ; 30 \mathrm{cts} .1 / 4 \mathrm{lb} . ; 10$ cts. oz

aiant Pera, new, and the largest of all, grewing to a length of 15 to 20 inches.......

D.ANDLION, Large Lenved: Leaves and plauts double the size of the common; cultivated for spring greens. $50 \mathrm{ets.} \mathrm{oz} . . . \ldots \ldots$ RGG PLANT: New Tork I'wryle. 50 cts. oz.............................. 5

5 10 
KOHL RABI: Early Purple $20 \mathrm{cts} 0 \mathrm{z}$. LETTUCE : Ice Cubbaje, vury large heads.

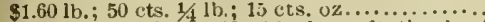
Early Temmis Biuli, (black seedl) the best early sort. $\$ 1.60 \mathrm{lb}, ; 50 \mathrm{cts}, 1 / 4 \mathrm{lb}, ; 15 \mathrm{cts} .0 \mathrm{z}$. Henderson's New York, very large heads one of the best summer varieties. $\$ 2.10$ lb.: 65 cts. $1 / 41 \mathrm{l}$.; 20 ets. oz.

Buctercup. new, yellowish green; very tender and rice. \$2.00 lb.; 60 ets. $1 / 4 \mathrm{lb}$; 20 ets. oz.....

The leacon, new, and the most reliable of all for summer, every plant forming a good head and slow to run to seed. $\$ 2.10 \mathrm{lb}$.; 60 ets. $2 / 4$ lb.: 20 ets. oz.

Green $F$ ringed, very tender and fluely friuged. $\$ 1.60 \mathrm{lb}$; $50 \mathrm{cts} .1 / 4 \mathrm{lb}$.; $15 \mathrm{ets}$. oz. I ELUN, MUSK: Casaba, large aud fine; rich 1lower. $\$ 1.10 \mathrm{lb}$.; $30 \mathrm{cts}, 1 / 4 \mathrm{lb}$.; $15 \mathrm{cts}$ oz. Huckensuck, a very popular market variety. $90 \mathrm{cts}$. $1 \mathrm{~b} . ; 25 \mathrm{cts}, 1 / 4 \mathrm{lb}$; 15 ets. oz ......... Nutmeg, small, rich and sugary. $\$ 1.10 \mathrm{lb}$. yontreat Market, vely large, round, and thick green llesh of good quality. $\$ 1.10 \mathrm{lb}$; $30 \mathrm{cts} .1 / 4 \mathrm{lb}$.; $15 \mathrm{cts}$. oz...

Perfection, uew, aud one of the very best; flesh rery thick of an orange-salmon colsr, very rich and sweet. \$1.25 lb.; $40 \mathrm{cts} .1 / 4$ lb. ; 15 ets. oz.............................

Emeruld Gem, new, small; yellow flesh and
Fery rich flavur. \$1.E0 lb.; 50 cts. $1 / 4 \mathrm{lb}$.; 20 ets. 0 z......

IELON, "W ITER: "Phinney's Eurly, very early, proliflc, rich and sugary. 85 cts. lb. $; 25$ ets. $1 / 41 \mathrm{lb}$.

Peerless, very early and ploductive; the richest and fluest flavored of all. $\$ 1.00 \mathrm{lb}$. 30 cts. $1 / 4 \mathrm{lb}$.....

$\boldsymbol{R u b y}$ Gold, new, very large, and one of the best melons ever introduced; flesh very sweet, golden yellow, viriegated with streaks of pink, making it the inost beautiful and novel melon ever seeu : per lb., $\$ 2.00$ 60 cts. $1 / 1 \mathrm{lb}$.; $25 \mathrm{cts}$. oz.

UUSTARD: White London. 60 ets. ib....

ONION: Early Red, very early. $\$ 2.50 \mathrm{lb}$.

75 cts. $1 / 4$ lb.: 25 cts. oz.

Wethersficld Lrerye Red. \$2.50 ib.; $75 \mathrm{cts}$

$1 / 4 \mathrm{lb}, 2^{2}$ cts, oz..... Giol.....................

Danvers Ycllow Globe, argely grown fo
market. $32.50 \mathrm{lb}$; $75 \mathrm{cts} .1 / 4 \mathrm{lb}$; $25 \mathrm{cts} . \mathrm{oz}$.

White filobe, very large, mild flavor, one of the best. $\$ 4.501 \mathrm{lb} ; \$ 12.51 / 41 \mathrm{~b}, ; 40 \mathrm{ets}$. oz

sece mmoth silver ising, very large, has been grown to weigh 2 lbs. each. $30 \mathrm{ets} .02$

OKIRA or GUJIBO: Dwarf Prolitir,.....

PARSLEY: Emeralil, rery finely curled,...

PARSN1P: The Stulcit, a vory sweet varie-

ty. \$1.10 ib.; $30 \mathrm{ets} .1 / 4 \mathrm{lb} \ldots \ldots \ldots \ldots \ldots \ldots \ldots$.

$30 \mathrm{cts}$. 02

sweet Hountäin or Mrimmoth, very mild. $\$ 1.001 / 41 \mathrm{lb}$; 30 cts. oz....................

Golden Drien, very large, productive and sweet; of a beautiful golden-yellow. $30 \mathrm{cts}$.

Ruby iring, new; very large aud extremely productive, uild flavor. $\$ 1.251 / 4 \mathrm{lb}$; $40 \mathrm{cts}$.

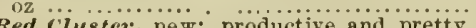
the small truits in clusters on the ends of the liancbes. $\$ 1.501 / 41 \mathrm{lb}$; 50 ct $\$$. Oz...

Celcstinl, a uew, remarkably haudsume and productive variety from China. The eruits are at ilrst creamy-yellow and change to brilliant scarlet, the two colors forming a time contrast; of superior quality, sharp flavor. $\$ 1.501 / 41 \mathrm{~b} . ; 50 \mathrm{cts} .0 \mathrm{z}$

PUMPKIN : Sugar, the sweetest and best

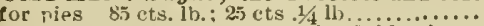
Large Cherse, the best sort for field culture and good for cooking; flesh very thick. 75 cts. Ib. ; $25 \mathrm{cts} .1 / 4 \mathrm{lb} \ldots \ldots \ldots \ldots \ldots \ldots \ldots \ldots$

Jumbo, the largest variety; has been grown to weight of $200 \mathrm{lbs} .75 \mathrm{cts} .1 / 4 \mathrm{lb}$; 25 ets.oz.

RADISII: Rol Turnip, early and tender.

75 cts, lb.: 25 cts. $1 / 4$ lb......................

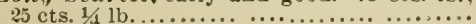

RADISI: Chartier, very large and tender. 40 cts. $1 / 4$ lb.; 15 cts.oz.....................

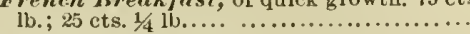

Chinese Rose Hinter, for winter use...... Manimoth White Winter, very iarge aud good. $\$ 1.10 \mathrm{lb} . ; 30 \mathrm{cts} .14 \mathrm{lb} \ldots \ldots \ldots \ldots \ldots \ldots$ RHUBAlls: 'Jinman, early, läge and tender, \$2.50 lh.; 75 cts. $1 / 4$ lb.: 25 ets. oz... SPINACH: Hound Lerf, the best for

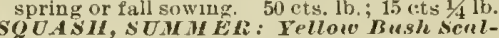
SQUASH, SUMMER: Yellow Bush serlloped. 25 cts. $1 \mathrm{~b} . ; 25$ cts. $1 / 4 \mathrm{lb}$.

Bush Crooknerk. $85 \mathrm{cts}$. $1 \mathrm{~b}, ; 25 \mathrm{cts}, 1 / 1 \mathrm{ib}$. SQUAS II, WINTER: Bostan Murrou, Essex, best for fall use. $\$ 1.10$ ib.; 30 cts. $1 / 4$ $1 \mathrm{~b}$

Cocoanet, a nice little fall squash; very prolific and succeeds where others fail; fluegrained and sweet. $\$ 1.10 \mathrm{lb}$.; $30 \mathrm{cts}$. $1 / 1 / \mathrm{lb}$. Hubburd, the standard of exccllence. $90 \mathrm{cts}$. lb.; 25 cts. $1 / 1$ lh

Mrerblehead, better than Hubbard in some respects. $90 \mathrm{cts}$. 1b.; 25 ets. $1 / 4 \mathrm{lh}$....... .. Bay State, new; remarkably productive, ana one of the Fery best of the wiuter sorts: llesh very thick, fine-grained, dry and sweet kceps best of all varieties. $\$ 1.00 \mathrm{lb} . ; 35$

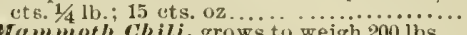

Mammoth Chili, grows to weigh $200 \mathrm{lbs} . .$. This vegetable should have a place in every garden. It is a delicious vegetable and is used in soups, also boiled and fried, and has the flavor of oysters. Sow and cultivate like parsuips. The roots may remain in the ground all winter. $\$ 2.00 \mathrm{lb}$; $75 \mathrm{cts} .1 / 4 \mathrm{lb}$.

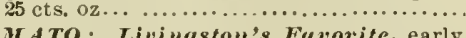

TOMATO: Livingston's Fuvorite, early, of good size, very solid, loulud and swlooth as an apple and of flrst rate quality. $\$ 3.10 \mathrm{lb}$.; $90 \mathrm{cts} .1 / 4 \mathrm{lb}$.; $25 \mathrm{cts}$. Oz...

Bealy, a $n \in w$, large and very bandsome sort of a peculiar pinkish-red color; very smooth and solid; one of the very best. $\$ 3.60 \mathrm{lb}$.; $\$ 1.001 / 4 \mathrm{lb}$; $30 \mathrm{cts}$. oz

Duraf Champion, the best of all the new sorts: very early, smooth and solid. 30 ets. oz .............................................. round, smooth and solid. 50 ets. oz........

Strawerry, or Winter Cherry, a distinet species, the fruit growing in a husk and about the size of cherries. It should be grown in every garden, especially. where fruit is scarce. It is very productive, and has the flavor of strawberries; excellent ior canning, and the fruit can be kept fresh in a dry place all winter. Culture like the com mon Tomato. $40 \mathrm{cts}$. O2

TURNIP, ENGLISII: Early White Flat Dutch. $10 \mathrm{cts}$. 1b.; $20 \mathrm{cts}, 1 / 4 \mathrm{lb}$

strap-leaved Red Top, early and good. 60

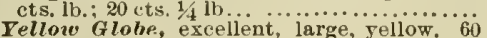
Yellow Glohe, excellent, large, jellow. 60

White $\boldsymbol{E} g g$, one of the best for the table. T0

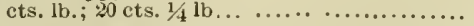

TURNIP, SWEDEOR RUSSIAN: IThite sweet, the best for table uso. 75 cts. 1b. ; 25 e.ts. $1 / 4$ lh

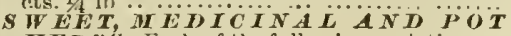
HERBS: Each of the following varieties are 5 cents per package:

Sucet Basil; Caraurey; Coriander. Catmint; Hourhoumd Lavender: Swret Marjorum ; Rosemary; Sage ; sinfron. summer savory; Hinter savory: Tans!y; Summer Thyme; Winter Thyme; Wormwood.

5 VEGETABLE ORANGE or MANGO MELON: A very pretty and useful now vegetable, bearing on a vine like a molon an abundance of small fruits the size, color and ghape of an orange. It is excellent for man goes, preserves or sweet pickles, Plant and cultivate like melons. $50 \mathrm{cts}, \mathrm{oz}, \ldots . . . . . .$. 


\section{PLANT DERTR'TMENT:}

I have every facility for the propagation and growth of Plants and my stcek is, at least, of as good quality as any in the country and I shall strive to gain as high a reputation for them as my seeds ncw have, and I hope all my customers will give them a trial.

In making up my list, great care has been taken to select the very hest and most distinct varieties of each class, and with this object in view a large number of varieties have been tested at Pansy Park, including some 200 varieties of Roses, 75 of Geraniums, 4 il of Fuchsias, 200 of Chrysanthemums, 50 of Coleus, 300 of hardy plants and other classes in like proportion.

Plants by Mail " Specialty: I shall make the sending of plants by mail a specialty and guarantee the safe delivery of everything ordered at any post-office in the United States or Canada. postage paid at all seasons of the year, no matter how filr away it may be. This will enable those who live in the most distant places to ohtain plants just as cheaply as they could if I had a greenhonse in their own town.

Plants by Express: Those who send large orders would do well to have them sent by express. I do not pay express charges, but somewhat larger plants can often he sent in this way, and I will always add extra ones enough to more than compensate for the charges. If ordered by express always give name of nearest express office, if difierent from post office.

All Plants will be packed in strong wooden boxes to iusure safe transit through the mails, hut if a package should become lost or stolen or its contents become in auy way injured I will send again.

No Substitution of Variefies will be made in any case uuless permission is giren to do so. This will be appreciated by those wlo have ordered plants of certain varieties and received otlier varieties in place of them. which were not ordered or wanted I intend to have everything offered constantly on hand, but as stocks of some kinds may sometimes become exbaustel it is well fol customers to name two or three extra sorts that may be substituted in case we sbonld he out of any of the sorts ordered.

No Order filled for a less umnunt then so rts: It ensts nearly as much to pack and inail a 15 or 25 cent order for plants as it dors for a dollars' worth. Last seastil we filled mauy such orders which of ten cost us mole for packing and postage than the amount received. and this season we are obliged to decline to fill any order for P HANTS for a less amount than 50 cents, unless ten cents extra, in addition to the price of the plants, is added for acking and pistage. If you only want a plant or two yourself, get a friend to join with you and thu : make up the required amount, save the ten cents, and also receive for your trouble one of the gift plants namied below.

A Gift fos all: To every order for plants. no matter how small it may be, we will add, gratis, one of the following named plants, customer's choice: Lchillea The Penl, Mexican Primrose,

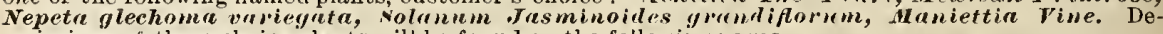
scriptions of these choice plauts will be found on the followiug pages.

In mreking out Plant (rrders, please keep separate from seerl orders, and not mix the two together. This will help us to arvid mistakes in filling.

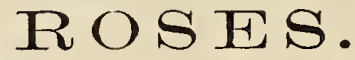

My Roses are grown in pots and all on their own roots, nice healt hy plants, equal to anv offered at same prices. Price of all Roses, except as otherwise priced, 15 rts, each, 4 for 50 cts., 9 for $\$ 1.00,2$ ) for $\$ 2.00$.

\section{EVERBLOOMING ROSES.}

The Monthly or Everblooming Roses mostly belong to the classes called Tea and Bourbon. They hegin to hloom early in the season when the plants are quite small, growing and blooming freely all summer when bedded out and until after severe frosts. Most sorts will stand the winter where the mercury does not fall more than 25 degrees below freezing. These are the varieties so much grown for winter blooming. When wanted for winter they ahould be grown in pots and all huds kept picked off during the suntmer, which will ensure an ahuodance of bloom in winter. Plants that have grown in the open ground in summer will give good results in winter if potted early in the fall, cut back, and kept in a cool place for two or three months hefore hringing to a warm room.

Catharine Mermet. Large rery double flowers, pink, shaded amher.

Chas. Rovolli. Beautiful, tender rose, dark centre.

Cornelia Cook, Creamy white, large and double. Devoniensis. Pale yellow, large and full.

Edward Gontier. Creamy yellow and buff, shaded crimson.

Etoile de Lyon. Magniflcent ; chromo yellow,

large double and full; one of the best.

Grace Davling. Porcelain rose, shaded crimson.

Madame Marthe du Bourg. Creamy pink, tiushed orange red.

Marie Dutcher. Rich transparent salmon.

Madrme Hoste. One of the most valuable of all Roses ; extra large flowers, very full and highly perfumed; color, soft canary yellow shading to pure goīden yellow in centre.

IIarie Van Houtte. Creamy white, tipped rose. Mad Welche. Light yellow and dark orange. 
Mad. de Haterille. Creamy white, each petal bordered light rose like a tulip.

Mud. Cusin. Rosy purple, pale centre.

Mulmaison. Large, lich flesh color.

Marshal Niel. The finest of all greenuouse elimbing Roses; large, deep sulpher vellow Howers.

Papa Gontier. Dark carmine crimson.

Perle des Jardins. Rich yellow, large and perfect form : one of the very finest.

Souv $D^{\prime}$ Un fimi. Deep rose coior.

Soue sle Wooton. Bright rrimson.

The Brille. Pure white, rery fragraut.

\section{POLYANTHA ROSES.}

A beautiful class of drarf Everblooming Roses. The flowers are small but they are very double and borne in large clusters of 25 to 100 flowers in each. If well protected with leaves or straw they are hardy in this latitude.

Cecile Brunner. Bright rose, sellow ceutre.

Mignonette. Blush white, flushad pink.

Perle $D$ 'Or. Reddish salmon.

Miniature. Very small, pure white.

\section{MOS'S ROSES.}

These are perfectly hardy and prized for their beautiful mossy buds and fragrance.

Conntess de Ifurinais. The finest pure white sort. $25 \mathrm{cts}$. each.

Glory of Mosses: Large, rosy carmine, 25 cts. each.

Luxembourge. Crimson, large. $25 \mathrm{cts}$. each.

\section{HARDY CLIMBING ROSES.}

\section{Prairie Queen. Bright pink, in elusters.}

Baltimore Belle. Blush, variegated rose and white.

Gem of the Prairie. Violet crimson.

Russel's Cottuge. Dark velvety crimson.

Mary Washington. Named and raised by

George Washington more than a hundred years ago. This fine rose was newly introduced to the public last year. The original bush is still to be seen at Mount Vernon. Its flowers are pnre white, double, and borne in great numbers.

Sweet Briar. This is the old English Swoet Briar Rose so bighly prized for its very fragrant foliage. A few plants will perfume a whole garden and it should be in all collections.

\section{HYBRID PERPETUAL ROSES}

The large size and fragrance of this class makes then the most valuable of all hardy Roses. They bloom profusely in June, and bear a few Howers at intervals through the summer and autumn if well eared for.

Alfred Colombe. Large, of very perfect globular form : armine crimson; $25 \mathrm{cts}$, each.

Abel Curvierc. Velvety crimson; large and double : $: 0$ cts. each

Aunie froorl. Brigbt crimson; blooms flnely in a utumn.

Anna de Dievbch. Very large and double, of a tieh carmine shade ; 20 ets.

American B+uuty. Tery double, of a deep crimsou color; 2 j cts.

Baron de Bonsteltin. Velvety maroon shaded with tleep crimson: $25 \mathrm{cts}$.

Coquefte des $\mathrm{ll}_{\text {, }} \mathrm{s}$. White, tinged with blush; full and of fine torm : $: 0 \mathrm{cta}$.

Dr. Reymont. Medium sized erimson flowers very freely produced.

muchess of Aloany. A new very profuse bloom ing sort. of a rich deep pink color.

Fisher IIolmes. Rich velvety crimson ; $20 \mathrm{cts}$

Gloire Lyonaise. White, tinted with yellow. $20 \mathrm{cts}$.

Gen. Jucqueminot. Bright crimson; very popular.

Gen. Wreshington. Rosy carmine; one of the very best.

Jean Liabaul. Velvety crimson shaded with maroon and scarlet; $25 \mathrm{cts}$.

Louis Vun Houtte. Cr.mson maroon; one of the tinest.

John Hopper. Bright rose, carmine centre.

Le France. Silvery rose and pink; a constant bloomer and the sweetest of all Roses.

Magna Chartu. Pink, suffused carmine.

Madame Plantier. Pure white; a profuse bloomer in June.

Prince Camille de Kohan. Very deep velvety crimson: $25 \mathrm{cts}$.

Pierre Nottiny. Large, deep crimson ; $30 \mathrm{cts}$

Paul Neyron. The largest Rose known; deep rose color; vigorous grower.

Rev. J. B. Camm. Carmine; a superb variety.

Olrich Brunner. Bright cherry red; large and fine ; $25 \mathrm{cts}$.

All Roses, unless otheruise priced, are $15 \mathrm{cts}$. each, $\downarrow$ for $50 \mathrm{cts} ., 9$ for $\$ 1.00,20$ for $\$ 2.00$.

\section{TWO BEAUTIFUL VINES.}

SOLANUM Jasminoides grandiflorum. A singularly beautiful plant of elimbing habit, grow. ing 3 to 5 feet high, or it ean be trained in bush form. Its flowers are about an inch across and are borne in large clusters often a foot across, and pure white. It is a splendid pot plant and a perpetual bloomer both summer and winter, and when planted out in sumner it is one of the finest 'things I know of for covering a fence or trellis, its magnificent elusters of snow-white flowers attracting the admiration of every one. It is of the easiest culture, growing freely in auy good soil. Fine plants, $10 \mathrm{cts}$. each, 4 for $35 \mathrm{cts}, 10$ for $80 \mathrm{cts}$.

MANETTIA TINE (Munettiu bicolor). This is another excesdingly pretty vine either for house culture or planting out iv summer. It is always in bloom, a plant being seldom found without flow ers. These are tibular in form, ahout an inch long and very striking in color, being brilliant scarlet tipped with bright rellow, and of a peculiar waxy texture, the same flower keeping in perfection fo several weeks. Its foliage is clean and glossy aud it will grow and bloom in any ordinary soil elimbing from 5 to 8 feet in a season. As a pot plant it is unsurpassed when trained to a stake or pot trellis. Plants in bud or blooming, $10 \mathrm{cts}$. each, 4 for $35 \mathrm{cts}$. 10 for $80 \mathrm{cts}$.

I want to write and thank you for the extra plants you sent with my order. They were all in excellent condition and I am rery much pleased with thein. I have never seen a more perfect small Palm than the one you sent.-Fasiy D. Foster, Nilford, N. H.

The plants reached me in good condition and I must say that I am well pleased with them and sulprised that they are so much larger than any I ever had seut to me before.-MLLLIE Dickson, Ladoga, Ind.

The Aquatic plauts which came yesterday were very satisfactory. The splendid way in which the were packed made them proof against the long journey thry had. They were just as fresh aud nice as when sent away.-Rev. C. J. CuRTis, The Parsonage, Wolverton, P. Q., Canada.

I receired my Roses last week and was delighted with them. I shall know where to get the best Roses hereafter.-ELdORA. D. FraNkL1X, Buruside, Ct. 


\section{Rare Aquatie Plants.}

The cultivation of water plants has increased very rapidly during the past few years. Gran'l displays of them have been made in the public parks of some of the large cities, and the time is not far. distant when no private place of any pretensions will be considered complete without its water garden. Nothing that can be grown will give more pleasure and no class of plants require so little care after they are properiy started. Those who have a warm, shallow pond, with a rich, muddy bottom, cau cultivate them with a trifling expense. Artificial ponds or tanks can be constructed of any size or shape desired by excavating the soil to a depth of two feet, covering the sides with an inch of cement. They can also be grown with good success in tubs made by sawing barrels or hogsheads in two. The soil for all kinds of aquaties should be composed of equal parts of good loam and old thoroughly decayed stable or cow manure, well mixed. Put 8 to 12 inches of this in the bottom of the tank or tubs, firmly packed down, then cover with two inches of sand or fine gravel to keep it from fouliug the water. After planting the roots fill up with 6 to 12 inches of water, which is ample and better than more. The water should be changed several times during the summer. Tanks or tubs should be placed where they will get the benefit of the sun for at least 6 or 8 hours during the day. Move tubs to a cellar in winter and cover tanks with boards, leaves or straw to keep out severe frost. The best time to move and plant all kinds of water plants in the open air is about the first of June and none of the tender kinds should be put out any earlier.

My collectjon of ornamental aquatics is one of the finest in this country and my exhibits of them at the horticultural shows in Boston and Springfield have been awarded first prizes and attracted much attentiou.

ORDER EARLY. As stock of some of the choicest kinds is limited, orders should be sent as early as convenient, which we will book and fill at the proper time for planting. Varieties marked with a* can usually be supplied at all seasons of the year.

\section{NYMPHAEAS OR WATER LILIES.}

\section{TENDER NYMPHAEAS.}

These, although of tropical origin, grow freely and flower profusely from July to frost in the open air anywhere in this country, and they may be flowered in warm greenhouses all winter.

\section{DAT-BLOOMING VARIETIES.}

The flowers of the following opeu about $9 \mathrm{~A}$. M. and close about 3 P. M.

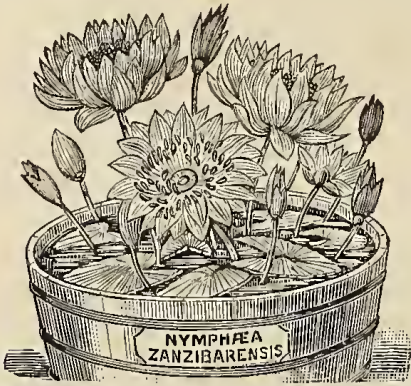

NYMPHAA Zanzibarensis vars. These are the easiest grown and most satisfactory of all the tropical Water Lilies. (For full description see page 4.) I offer plants this season at lower prices than ever.

N. Zanzibarensis azurea (Blue African Water Lily): Fine plants in May and June which will begin to bloom in 30 to 40 days after plauting, 40 cents each.

$\boldsymbol{N}$. Zanziburensis rosea (Fed African IVater Lily): Fine plants in May and June, 40 ets. each. N. Zanziburensis (The Royal Purple Water Lily). This is the typical variety and is of a deep rich blue or purple color: \$1.00 each.

$\boldsymbol{N}$. scuctifolia. A fine species from South Africa with flowers 4 to 6 inches acrnss, pale blue or lavender shading to white in the centre. A very free-blooming and easily grown variety. 50 ets, each.

N. stellata (Egyptian Water Lily). A very freeflowering species, the flowers 5 to 6 inches across and of a beautiful sky blue. $\$ 1.50$ each.

N. elegans. A pretty species from New Mexico, with small white flowers tinted with pale blue. $\$ 1.50$ each.

V. gigantea (Australian Water Lily). A magnificent species with large purplish blu $\rightarrow$ fowers shading to white in the centre. Very rare and scarce. Price $\$ 4.00$ each.
N. Mexicana (Mexican Wuter Lily). The flowers of this choice voriety ale 3 to 4 inches across and of a rich golden vellow color and are produced freely through the season. $75 \mathrm{cts}$. each. $\boldsymbol{N}$. flava. This is a native of Florida and resembles Mexicana in all respects except that it does not flower well at the uorth. $50 \mathrm{cts}$. each.

\section{NIGRT-BLOONING VARIETIES.}

The flowers of the following open about sunset and remaiu open till nearly noon the next day.

NYMPHAA Devoniensis. This is perhaps the choicest and most gorgeous Water Lily in cultivation. The flowers, which are of a brilliant rosy red with scarlet stamens, will. with liberal treatment attain a diameter of 10 or 12 inches. It blooms very freely, from 4 to 10 flowers often opening on a plant at one time. Fine plants in May and June, $\$ 1.50$ each.

N. rubra (East Indian Water Lily.) This closely resemoles Devoniensis, but the flowers are more cup-shaped. $\$ 2.00$ each.

N. Sturtevanti. This also resembles Devoniensis, but the flowers have more petals and are more cup shaped, and it is not so freeflowering. \$5.00 each.

$\boldsymbol{N}$. dentria (White African Water Lily). The largest and finest white variety known; flowel's as large as those of Devoniensis and of a chalky white. It is very easily grown, blooming freely all summer and should be in all collections Plants in May and June, 50 ets. each.

N. lotus. A large fine white species from lower Egypt. $\$ 1.50$.

VICTORIA regia Randi, (New Crimson-flow ered Victoria regia). This is the Queen of $\mathrm{Wa}$ ter Lilies and the largest acquatic plant known. The leaves grow to a diameter of six or eight feet, and the flowers 12 to 16 inches. each plant eovering a space 20 to 30 feet across. The flowers emit a perfume resembling that of pineapples. At first they are white, changing to a deep crimsou the second day they open. It can be easily grown in the Southern States in open ponds. It can be flowered in the North in green-houses, or in a tank in the open air. Start the seeds which are about the size of peas, in winter or early spring in water and put them near the pipes in a green-house or in some place where they will keep at a uniform temperature of 80 or 90 deg., till they sprout, then plant in pots of rich soil. To grow it to perfection in the open air, the water in the tank must be heated artificially with pipes from a green-house boiler, but it can be flowered with fair success without the aid of artificial heat as I proved duriug the past summer. A plant was set in a rich bed of soil in a pond early in June and eoveled with an 
ordinary cold-irame nntil hot weather set in. It grew very rapidly, making leaves $51 / 6$ feet across, and produced a number of flowers in $\mathrm{Au}$ gust. Sceds, 50 cents each, \$.; per doz. Plants, $\$ 5$ to $\$ 10$ each, ready early in June.

EUR $\boldsymbol{Y} A L \boldsymbol{E}$ ferox. An East Indian species of Water Lily which, excepting Victoria regia, is the largest aquatic plant known. The leaves are 2 to 3 feet across, of a rich olive green veined with red. The flowers are suall, of a violet pur ple color. This species will grow and flower with the same trcatment giveu the Zanzibur varieties. Plauts, in June. $\$ 5.00$ each.

SPECIAL OFIFR: For st.jo we will send one plant each of N. Zanzibarensis azmea, N. Zan zibarensis rosea, N. scutifolia and N. dentata.

\section{HARDY WATER LILIES.}

No kind of Water Lily will bear actual freezing of the roots, but those that will stand the winter in cold elimates are called bardy. They can he easily grown in pouds, tanks or tubs.

Nymphere Marlictea chromatella (New Sel Low Water Lily). This lovely varicty has been flowered for two sears here; it is pertectly hardy and truly a gem. The plant has the vigorous hahit of albe candidissima. and it flowers continuously from May to Oet. The flowers are fragrant, 4 to 6 inches across with hroad, waxy petals, of a beautiful light yellow color with bright orauge stamens. Plants, $\$ 1.50$ each, three for $\$ 4$.

N. Marliacea carnea. A variety of the above of a delicate blush or flesh color. \$2.50 each. N. Marliacea rosea. Of a delicate rose color. $\$ 2.50$ each.

v. Marliaren albida. Like the above, but pure white. \$2.50 each.

N. Laydekeri roser. This is the newest and one of the finest of the hardy varieties. Tho flow ers are about 3 inches across and vary iu color from a deep pink to pale rose on the same plant. It is a very free bloomer and will no doubt beconie a popular variety. $\$ 5.00$ each.

N. odlorata. The common native Water Lily of the Eastcru States. Good flowering roots, 30 cents each : four for $\$ 1.00$. (Roads in May.)

N. odorata minor. A variety of the commou, with flowers onls lialf the size. Price, 30 ceuts each.

N. odorata rosea. This is the rare pink variety of odortitu, sometimes called the Cape Cod Pink Lily, and is the niost lovely of all the hards varieties. It hegins to bloom earlier in the seasou and contiules in bloom later than the conimon rariety, and is of a lovely pink or rose color. I have a fine stock of this rare variets and anl able to offer them at a greatly re. duced price this scason. Price, good flowering roots, $\$ 1.25$ each, two for $\$ 2.25$, three for $\$ 3.50$, six for $\$ 6.25, \$ 12$ per doz.

v. oflorata sulphurca. A new very scarce jellow variety. $\$ 3.00$ each.

$\boldsymbol{N}$, odorctu exquisitu An elegant very rare rariety of a rosy carmine, a deeper color than odorita rosea \$3.00 each.

V. odorata gigumea. A gigantic form of the cominon Water Lily, which was diseovered last year in Florida and is now first offered. The leaves are very large, thick aud heavy with curiously ruffled edges. Flowers fragrant, pure white with a golden yellow centre, aud of a decided cup-shape, giving it a vers distinct appearance. Price of tine roots, 30 cents each, 4 for $\$ 1.00$

v. odorata Carolimensis. A grand novelty and the largest of ull the odorota varieties. The Howcrs are 5 to 7 inches across, of a delirate sa! mou rose color, very fragrant and borne very freely through the summer. $\$ 1.00$ each.

). alba. This is the uative Water Lilyof Eurove. It has larger Howers and blooms earlier and later in the season than odorata. $\$ 1.00$ each.

v. albu cundidissima. This is a large-flowered variety of the above and the finest of all hardy $\mathrm{va-}$ rieties. It is much better than our hardy varie$\mathrm{t}, \mathrm{s}$, beginning to flower earlier and continues in bloom till frozen up iu the fall. The flowers are pure white, the petals being very broad and much more waxy than those of $N$. odorata and in rich soil will grow up to five or six inches across. Good flowering roots, each, \$2.00. (Ready in May.)
N. ulbu rosea. A very choice and rare variety from Sweden of a pale rose color, with the free thowering habit of $N$. albe, $\$ 5.00$ each.

$\boldsymbol{N}$. pygmoer. This is the smallest of all Water Lilies and a little gem. It is a native of Siberia and China. It blooins very freely, heing the first variety to flower in summer, and continues till frozen up in the fall. The flowers aro pure white and about the size of silver half dollar, opening th noon and elosing at night. Plants, $\$ 1,00$ eacli. (Ready iu Mas.)

N. pyymare heleola. A fine, rare variety with pale yellow flowers and browu spotted leaves. \$2,00 each.

N. tuberosa. This is the native Water Lily: of the Western States: Largo white Howers. 50 ets, each.

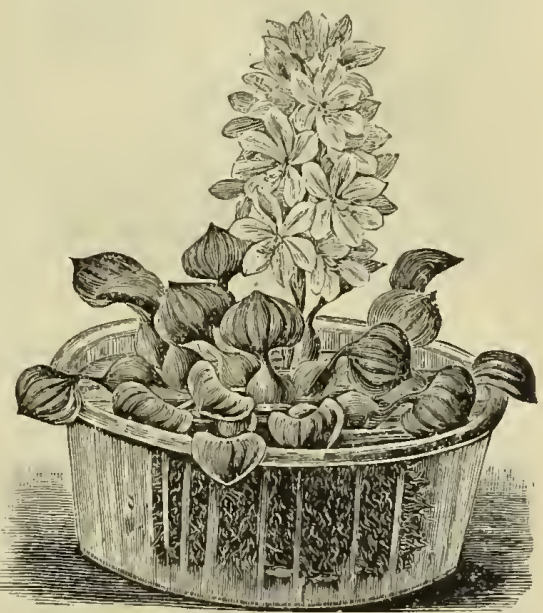

"EICHHO RNIA crassiges major, (The Water Hyrcinth, or Orchid Water Lily). A plant of very easy cultivation and great beauts. It has glossy dark green leares which have curiously in flated stalks which cause the whole plant to float on the water. It bears large spikes of the most exquisite flowers tlat can he imagined, resembling in form a spike of Hyacinth bloom, hut as beautiful as many of the choicest and most costly Orchids. Each nower is two inches across, of a soft lilac rose, sparkling as if covered with diamond dust. One of the petals in each flower has a metallic blue blotch in the center encircling a deep golden yellow spot. If set on the edge of a pond in rich soil where the water is only two or three inches deep it soon spreads and forms a large mass of plants, bloomiug freely for several months. It can be grown iu the house in winter in a tub or anything that will hold a little rich soil and water. It is a great curiositr and rell worth growing even if it had no flowers. $15 \mathrm{cts}$ each, 3 for 35 cts.. 10 for $\$ 1.00$.

E. azurea (Blue Water Hyacinth). A new and very choice variets. The flowers closely resemble crassipes major, but they are light blue, with a deep inaigo blue center. The plant hrauches freely and creeps in all directions in sballow water like a Verbena on dry land, aud blooms continuously throughout the season. Winter in a greenhouse. Plants, after first of June, $10 \mathrm{cts}$. each.

PONTEDERIA corduta. A fine native hardy aquatic with spikes of blue flowers all summer. Shallow water, $25 \mathrm{cts}$. each, 5 for $\$ 1.00$.

*PIsTlA stratiotes, (Water Lettuce). A Florida plant of great beauty. It forms a rosette of beautiful leaves ahout six inches across, which feel and look as if cut out of greenish yellow velvet. Treat like Water Hyacinth. $25 \mathrm{cts}$, each, 


\section{Rare ared Gorecors Fotrs.}

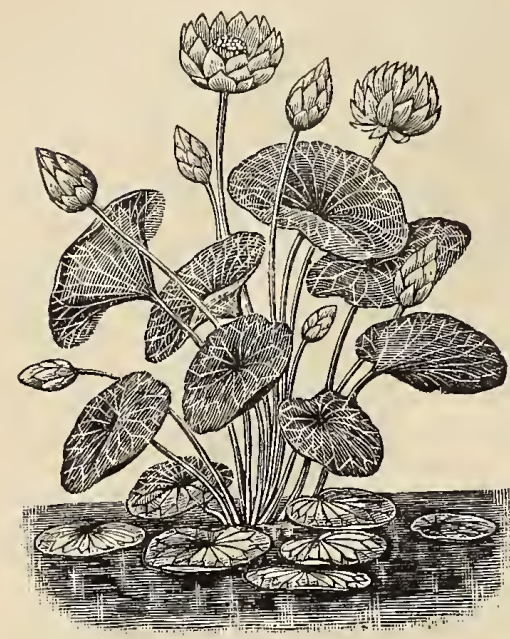

LOTUS PLANT.

Few are aware that the gorgenus "Sacred Lotus" of the Egyptians and Hiodoos, which has played so prominent a part in the crremonies and religious rites of these peoples as fal back as bistory extends, is perfectly hardy in this cnuntrs and cau be grow with the greatest ease : yet such i the fact. It is perfectly hardy here, laving pass $d$ several winters where ice formed a foot or more thick over th $\rightarrow$ roots. They can be grown in any warn pond having a rich mud bottom. Plant the tubcrs 4 or 3 inches deep in the soil in water not over a foot deep ind they will take care of them. relves. They also grow and blossom freely in large tubs. If planted in tanks or artificial ponds where other plants are grown the roots of the Lotus stould be cozfined in the corners by brick partitions, otherwise they will soon overrun other things. The first size roots I ofier will flower the first year. These are too large to send by mail, and must go by express at purchaser's expeuse. Fecond size roots will not flower the fi'st year and can k/e ; eut by mail. Lot us roots should only be moved and planted about the first of June.

Neiumbium o ose "... (Japanese, or East Indian Lotus). This is the finest of all the valieties of Lotus. Its grand circular foliage oft $n$ measures two feet across and its flowers 12 inchf $\mathrm{s}$. and it iv in constant bloom from July to frost. Each flower opens four times, the first oay resembling gigantic rose buds, of a deep bright rose color. The second day they ofen like a Tulip, the base of 1 he petals being $l i{ }^{2}$ ht pink, shading off bright rose coior at the tips. It has more petals than any other variety and might be called semi-double. This varieiy does best iu a heavr, rich, loamy soil. Price of first size tubers, $\$ 2.00$ each, 6 for $\$ 10.00$; second size $\$ 1.00$ each, sis for $\$ 3.00$.

N. album qrandiflorum, (White Japanese Lot $u s$, ) A rare and very beautiful pure white variety. First size tubers $\$ 2.00$ each: second size $\$ 1.00$ each.

N. album striatum (Striped Japanese Lotus). A magnificent and very distinct variety. The flowers are white, the edge of each petal irregularly marked and splashed with crimson. Very rare. First size tubers only, $\$ 2.50$ each.

N. speciosum (Egyptian Lotus). This is the parent of the above varieties. It resembles roseum but is paler in color and not so good. This does best in a rich clay soil. First size tubers $\$ 2.00$ each, two for $\$ 3.50$. Second size $\$ 1.00$ each.

$\boldsymbol{N}$. luteum (American Lotus). A native of the Southern and some of the Western States. The flowers are as large as the above and of a sulphur yellow color. First size tubers \$1.C0 each.

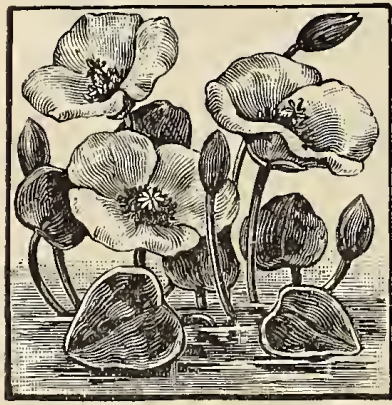

WATER POPPY.

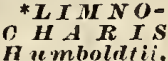
Water Poppy A showy and easily cultivated plant bearing an abundance of lemon yrllow flowers three inches across all summer. It has oval floatiug tiplies by means of runners which creep about in shallow water. Cultivate like Water Hyacinth. Plants, $15 \mathrm{cts}$. each, 3 for $40 \mathrm{c}$. IIMNOCHARIS Plumieri. A fine plant a foot or more tall with elliptical leaves 6 inches long, of a rich velvety green. Flowers in spikes, lemon yellow. Tender. $50 \mathrm{cts}$. each.

ORONTIUM aquaticum (Golden Ciub). A pretty hardy plant with spikes of yellow flowel's. $25 \mathrm{cts}$. each.

oUVIRADRA fenistrulis (Lace-leaf Plant). This is one of the most remarkable plants in the world, a native of Madagascar. The leares are 6 to 18 inches long and 2 to 4 wide, spreading out horizontally beneath the surface of the water. They are of a dark olive green color and merely a network resembling lace or a skeletonized leaf. Plant in pots of rich roil and place in a tub of water in a shady place, changing the water often to keep it elean and fresh. Tender. $\$ 5.00$ each. APONOGETON distacliyon. An interesting bardy water plant with spikes of small white, fragrant flowers. Plant in shallow water. $75 \mathrm{cts}$. each.

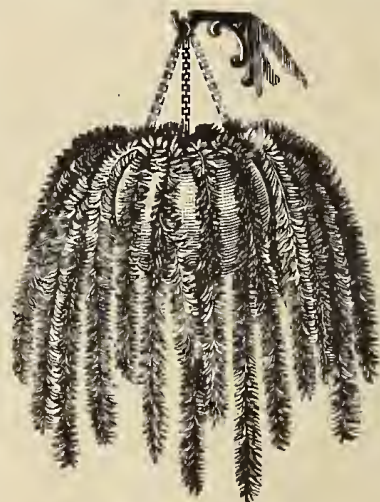

* $\boldsymbol{I I} \boldsymbol{Y} \boldsymbol{R} \boldsymbol{I}$ $O P H T L L D M$ Froserpinaco ides, (Par. rot's Feather.) An aquatic hang. ing plant is a great novelty indeed. It s long t railing stems are cov. ered with whorls of the most exquisice foliage as fincly cut as the leaves of the $\mathrm{Cy}$. press Vine and much more deli. cate. Planted in a water-tight hauging ba-ket with a little waterkept standing on the surface

PARROT'S FEATHER. of the soil it will trail over the sides in the most graceful manner. Can also be grown in shallow water anywhere. Hardy. 15 ets. each, 3 sor $35 \mathrm{cts}, 6$ for $60 \mathrm{cts}$.

SAGITTARIA Japonica fl, $p l$. (Doubleflowered Arrow-Head). This will make a grand addition to any collection of Aquatics. The flowers are snow white, as large and double as a Balsam and borne on spikes two feet tall. Perfectly hardy. Plant in water not over 6 inches deep. $30 \mathrm{cts}$. each, 4 for $\$ 1.00$

Monteviliensis, (Giant Arrou-Head). Four feet tall and very ornamental. Flowers in large spikes, pure white spotted with purple. Winter in the house. Plants, ready first of June, 25 cts. each. BRASENIA pellata (Water Shield). A fine plant for aquariums or the edge of an aquatic garden. 25 cents each. 


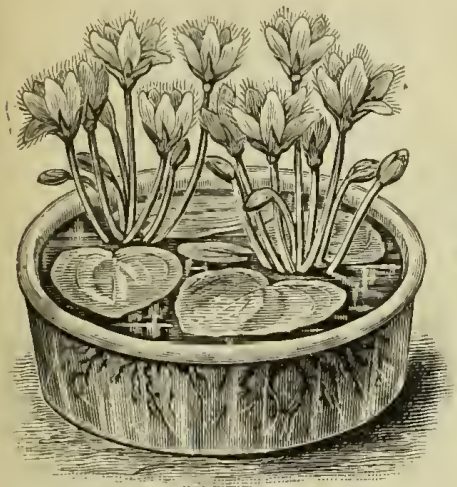

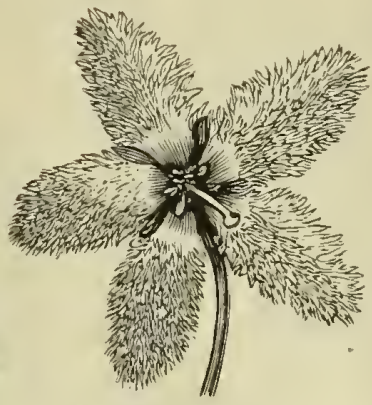

WATER SNOWFLAKE.

A flower, natural size.
C I Y N T T E MU U INDICUM, (II ater snor-flake.) This charming novelty attracted the admiratiou and wonder of visitors to Pausy Park last sunmer. Its manner of growth is very singular. The plant throws up leaves to the surface of the water like a Water Lily and the fiowers are produced in clusters upon the stem of the leaf. The flowers are white and an lnch or more across, the petals eovered with a delicate tringe as shown in the engraving, giving them the appearance of starshaped snowtlakes. They are produced freely ail summer, and all winter

if kept in a greenhouse or a warm room. A very pretty arrangement is to take a large glass dish, put in an inch or two of rich soil, set the plant in this, then cover the soil with gravel and pebhles, fill up with water and place in a sunny window. In a tub or shallow pond it will hloom freely all summer. 30 cts, each, 2 for 50 cts.

LIMNANTHE,H UM trachyspermum. An interesting plant resembling a small Water Lily,
with pretty white flowers an inch across. Hardy. 25 cents each.

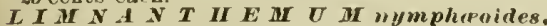
(European Flouting Heart). A pretty and perfectly hardy plant with floating leaves and an abundance of golden yellow fiowers an inch across Set in shallow water. 15 cents.

* AZOLLA Caroliniana, (F'loating Moss). An interesting hardy plant which hears no flowers, but its foliage resemhles a lovely green moss, A small plant put in a rlish of water soon covers the whole surface, $25 \mathrm{cts}$. each.

SALVINIA Brizilinsis. $\Lambda$ pretty little floating aquatic, the leaves of a soft green color covered with delicate hairs. 25 cents.

PAPTRES antiquorum, (Eguptian Paper Plant). A fine plaut with triangular stalked leaves 3 to 8 feet high. Grows in shallow water. Tender. $30 \mathrm{cts}$ each, 4 for $\$ 1.00$

CYI'ERUS alternifolins. The reedy stems of this plant have tufted heads resemhling miniature palm trees. $25 \mathrm{cts}$. each.

C. strictus. This resenhles the ahove hut is six to seven feet high. Tender. $50 \mathrm{cts}$, each.

ZIZANIA argutica, (Indian Rice). A highly ornamental native annual grass with large, graceful panicles of bloom 5 to 10 feet high. Plant in shallow water. Plants, early in June only. $10 \mathrm{cts}$, each, 3 for $25 \mathrm{ets}$, 6 for $40 \mathrm{cts}$., 20 for $\$ 1.00$

ACORTS Japonicus variegatus, (Variegated sireet Flag). One of the finest variegated-leat plants in cultivation. It can he grown with ease either in shallow water, or it does equally well in the garden planted out like a Canna. The leaves are a foot or more long and two inches wide, one half of each leaf beiug green and the other half pure white. It is perfectly hardy and a grand plant for edging to a hed of foliage plants. 25 cts. each, 3 for 65 cts., 6 for $\$ 1.10$.

SCIRP US Tabernamontani zebrina, (Porcu. pine Plant). This is another remarkahly fine variegated plant, a species of Rush, perfectly hardy and may he cultivated same as the Variegated sivet Filag. The leares are four feet tall variegated with alternate hands of green and white just like the quills of a porcupine. $25 \mathrm{cts}$. each, 5 for $\$ 1.00$

LOBEIIA rardinalis, (Cardinal Flover), A vely show, native hards plant with tall spikes of brilliant dark searlet flowers. Very fine for the margin of a pond, or may be grown in moist ground auy where. $25 \mathrm{cts}$. each, 5 for $\$ 1.00$.

The attractiveness of a water garden is greatly enhanced by a good ked of the large foliage plants planted close to the margiu on the north or hack side, such as Cannas, Caladiums, Castor Beans, Nusas, Bamboos, the large Grasses, \&c. The following are the best hardy solts adapted for this purpose :

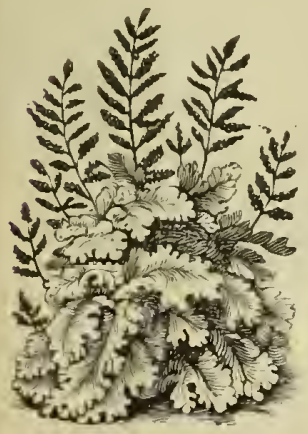

BOCCONIA.
BOCCONIA cor-

$d a t u$. A grand plant 4 to 6 feet tall with large, hands ora e leaves and enormous panicles of small $w$ hite flow ers. 30 cts., each, 4 for $\$ 1.00$.

\section{ARUNDO domax.}

$A$ giant species of reed or $\mathrm{B}$ a $\mathrm{mboo}$ from 12 to 18 feet tall. 50 ets each.

ERIA NTH US Ravemme. The largest of all the hardy grasses, ha $\mathbf{r}$ in $\mathrm{g}$ large plumes of flowers on stalks 10 to 12 feet tall. 30 cts, each, 4 for $\$ 1.00$.
EULALIA Japowicre variegata. A very fine grass from 4 to 6 feet high, the hroad leaves striped with white. 30 cts cach, 4 for $\$ \$ .00$.

Japonica zebrima. This is the hest of all the large grasses the leaves being marked erosswise with broad ereams-white hands. In the fall it throws np tall, elegant. feathery plumes o fiowers, which $\mathrm{n} \mathrm{re}$ splendid for winter decorations in the house. Fine plants. 30 r.ts. each, 4 for $\$$ ? gracillime univitetu. ALLALIA ZEBRINA eies forming clumps 4 feet tall. with large

very gracefu1, reculved leaves. $30 \mathrm{cts}$, each, 4 for $\$ 1.00$

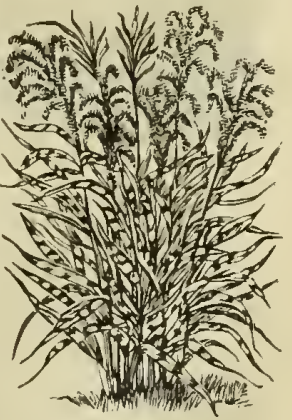




\section{NEW AND CHOICE ROSES.}

\section{EVERBLOONERS.}

Brillesmaid. Here we have a new Tea Rose and the best pink variety. Its buds are of exquisite shape and its keeps its clear, bright pink color under all ennditions of the weather. A good indication of its great value is the fact that florists are planting it in quantity for eut flowers, and it is undoubtedly destined to become very popular. $35 \mathrm{cts}$. each : 3 for $\$ 1.10$,

Kaiserin Augusta rictoria. This not only has a royal name, but is truly a royal Rose. It is of the purest white and elegant both in bud and when fully open, having large petals and a rich perfume. It is of vigorous growth and a continuous bloomer, produeing buds and flowers in the greatest profusiou. $45 \mathrm{cts}$. eacl.

Marion Dingee. This is undoubtedly the finest crimson Tea Rose ever introduced. It is of American origin and a strong vigorous grower. The flowers are large, beautifully cup-shaped and borne in wonderful profusion, and a plant is never without flowers. It is a deep, brilliant crimson and one of the darkest and richest colored of all the Tea Roses known $25 \mathrm{cts}$. each.

Rainbow Here we have a great novelty indeed -a real striped Tea Rose. The color is a lovely shade of pink, striped and blotched with crinasou. It is a most beautiful variety and attracts universal attention. It originated in California and was awarded the highest premium-a silver cup-by the California Floral Society. 20 ets. ea. Madame Pierre Guillot. A unique and remarkable variety and one af the finest of recent introduction. The flowers are large, full and globular, of a delicate orange yellow color, veined and bordered with clear pink. It is a good healthy grower and a regular, constant bloomer. 20 cts. each.

clotilde Soupert. This elegant new Tea-Polyantha Rose will be a great favorite. The flowers are of medium size, very double, pearl white flushed with carmine in centre, and they are produced in large clusters in profusion. The plant is a strong and vigorous grower. $15 \mathrm{cts}$. each.

\section{HARDY PERPE'IUALS.}

King of sweden. This is by far the richest, deepest colored Rose yet introduced-so dark in fact as to seem almost black. It is large, double, very fragrant and of a dark, velvety, crimson maroon, and should be in all collections. 25 cts. each.

Augustine Guinnoiseau (White La France). In this novelty we have a great beauty indeed. It is identical with La France in everything except color, which is pearly white, sometimes tinted with fawn. It can be highly recommended either for garden culture, or the house in winter. "5 $\mathrm{cts}$. each.

Mrs. John Laing. The flowers of this superb

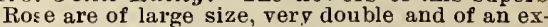
quisite shade of shell pink in color. It is very free-flowering, being in bloom nearly the whole season, and one of the finest hardy varieties ever sent out. $20 \mathrm{cts}$. each.

Dinsmore. On account of its hardiness and pro. fuse blooming qualities, this grand Rose is highly recommended for garden culture. Flowers are large, double, very fragrant and of a rich crimson scarlet color. $20 \mathrm{cts}$. each.

Mrs. Degruw. This is a real hardy everblooming Rose. From early summer until frost it can be depended upon to produce flowers of large size in abundance. Color, a rich glossy pink. $20 \mathrm{cts}$. each.

Vick's Caprice. A most striking and valuable new hardy Rose. The flowers are large, slightly cup-shaped, of a clear satiny pink color, distinctly striped and dashed with white and carmine. It makes elegantly shaped buds and is one of the most fragrant of all varieties, 25 . cts. each.

SPECIAL OFFER: For $\$ 2.50$ we will send one each of the above 12 new and choice Roses.

\section{NEW COLEUS.}

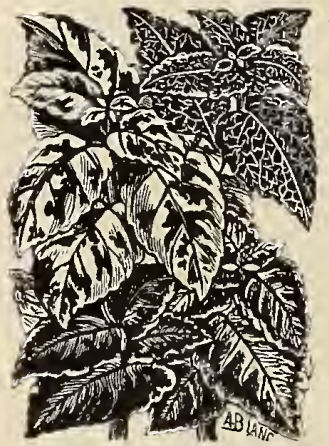

Beckivith's Gem. This is without exception, the most beautiful Coleus yet introduced, either for house or garden culture. The center of the leaf is rich relvety maroon, encircled with a zone of brilliant crimson and scarlet, the margin green and yellow changing to white and pink. It is a strong, vigorous grower and keeps its hrilliant colors through the dryest, hottest weat her, without fading in the least. $15 \mathrm{ets}$. each; $\$ 1.25$ per doz.

Lu Tete $D^{\prime} \mathrm{Or}$. A unique and elegaut variety, entirely unlike any other. The leaf is nearly round with a toothed margin and sharp point; color black, sometimes clouded with crimson, edged with yellow and pale green. $15 \mathrm{cts}$. each.

Alhambra. A very fine and brilliant varifty. Leaf rich dalk bronzy maroon with a large distinct, brilliant carmine centre, retaining its col. ors when bedded in the full sunshine. $15 \mathrm{cts}$ ea. SPECIAL OFHER: One each of the above 3 Coleus for $35 \mathrm{cts}$.

Coleus in variety. In addition to the above, I can supply 50 other sorts at 10 ets. each; $\$ 1.00$ per doz.

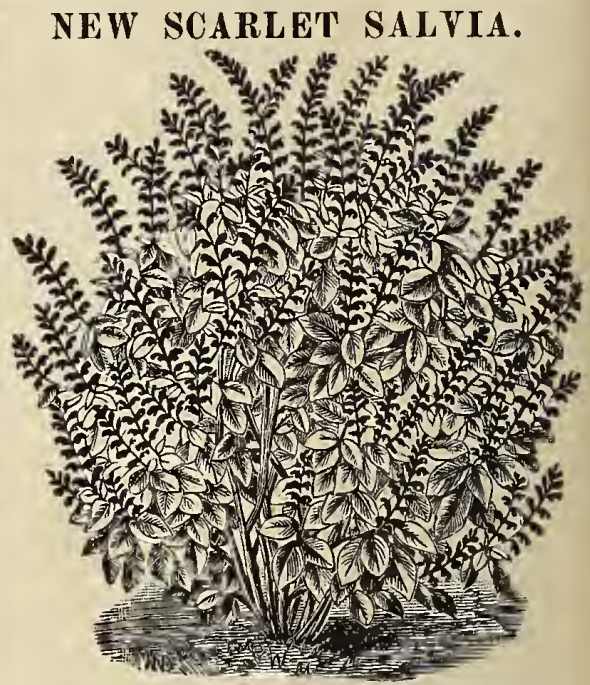

Salvir splendens campacta. As everybody knows, the Scarlet Salvia is tbe most brilliant and valuable of all, bedding plants. This new variety is much superior to the old sort in several respects. It is of low. compact, bushy growth, seldom over 18 inches in height, and so thickly covered with its large spikes of flow ers as to be a perfect mass of brilliant scarlet, and it blooms from June to frost. It" is also a superb plant for winter blooming in the house. $10 \mathrm{cts}$. each ; 4 for 35 cts.; 13 for $\$ 1.00$. 


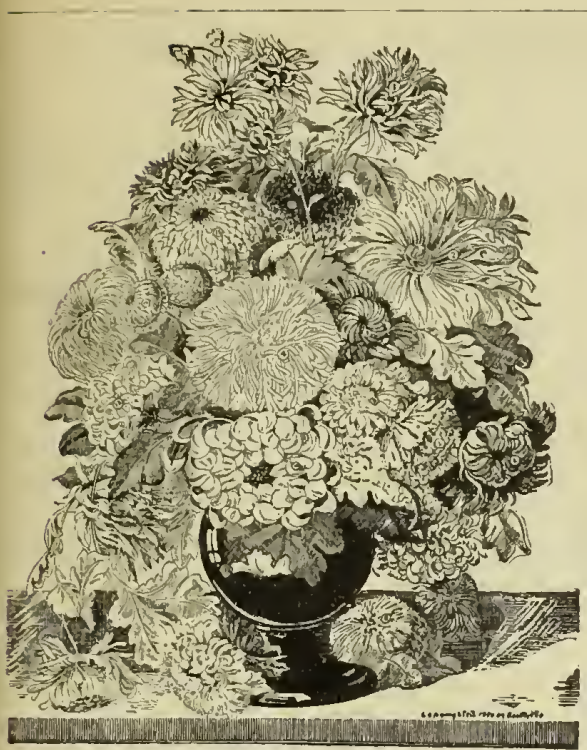

CHRYSANTHEMUMS.

\section{CHR YSA NTHEMUMS.}

The Chrysanthemum, aptly ealled the Queen of Autumn, is so easily, grown and gives such an abundance of flowers at a season when all other flowers are scalce, that it is no wonder it has become so popular. Plants should he obtained from Fehruary to May and can he grown in pots during summer, or may be planted out in the garden as soon as danger from frost is past. and potted up for the house about the nrst of September. To make nice, stocky plants, pinch off the ends of the branches during the summer as often as trey get 3 inches long, until the middle of August. 1 t large flowers are wanted pick off all huds as soon as they appear. except one on each braneh, and give plenty of liquid inanure when buds are forming. I can supply about 200 varieties, but the following are the very hest and most distinet of the lot and include the finest noveltips of the season, which are great improvements over anything hefore offered.

\section{The Ostrich Plume Section.}

The petals of these variaties are covered with a soft feathery growth of hairs which gives them the anpearance of ostrich feathers. They are the most lovely of all.

Patvicle rierry. Flower large, of a pure goldeu yellow with hroad thick petals. Novelty of this season. $25 \mathrm{ets}$. each.

Louis Roehmer. Silvery pink, shaded with rose; large flower with incurved petals. 15

Irs Annie Manla. A perfectly double flower of a creamy white changing to pure white when fully open and quite fragrant. $25 \mathrm{cts}$. each.

Wm. Falconer. A new variety with large flowers of an exquisite shade of rosy blush changing to a delicate fiesh pink when fully open, the bairy growth usually being a shade lighter than the body nf the petals, the effect of this being to give them the appearance of being covered with a lace-like weh. $20 \mathrm{cts}$. each.

Mrs. Alpheus Hardy. Flowers of large size, very double, with incurved petals, which are of the purest white. When well grown this is the finest of all white varieties. $15 \mathrm{cts}$, each.

SPECIAL OFFER: For $80 \mathrm{cts}$. I will seud the above 5 Utrich Plume Chrysanthemums.

Mrs. L. C. Malleira. This superb new sort has flowers 3 to 5 inches in diameter, of a perfect globular form, the petals like large closed quills and regularly incurved. Its color is a bright-orange yellow. $25 \mathrm{cts}$. each.

o.P. Bassett. Rich crimson scarlet, perfectly double, of regular form and the largest and best red variety yet produced. $30 \mathrm{cts}$. each.

Exquisite. This is truly an exquisite variety. Flowers of immense size, 6 to 8 inches across, very double and of a lovely shade of rosy pink. $25 \mathrm{cts}$, each.

Harry May. Flowers very large and double with hroad thick petals, of a deep old gold eolor with reddish tinge. $25 \mathrm{cts}$. eacl

Mrs. Johu Westcott. Creamy pink shading to creamy white. Flowers of enormous size; when well grown from 7 to 10 inches across. 20 cts, each.

Mrs. Murla Simpson. Color soft chrome yellow; very large and a fine example of the hroad pet aled incurved Japanese type. * 5 cts. each.

Golden Weddiug. This magniflcent noveity is without excaption the best golden rellow variety ever introduced. It is of the richest golden yellow, Intense and dazzling in color. Flowers 6 to 8 inches in aiamet $f r$, very deep and perfectly double to the centre, the petals broad, long and gracetully incurved. Has just won a silver medal at Philadelphia, two silver cups, and also the first prize for the hest yellow variety at the great New York show. Plants, reary March 1st, :0 cts. each; after May 1 st, price $35 \mathrm{cts}$, each.

SPECIAL OFFER: For only $\$ 1.50$ we will send one each of the above 7 grand novelties. Diana. Pure white perfectly doible glohular fiowers, resembling an Aster. $10 \mathrm{cts}$, each.

Gloriosum. Sul phur jellow ; very early. $10 \mathrm{cts}$, each.

Frunle Wilcox. Rich golden amber, $10 \mathrm{cts}$, each.

Lillius $\boldsymbol{B}$. Bird. Enormois very double tlowers with long tuhular petals of a beautiful shrimp pink color. Very distinct and one of the very best. $15 \mathrm{cts}$. each.

Cullivgfordi. Deep, rich crimson, large and perfectly double. $10 \mathrm{cts}$. each.

Moonliglit. Large creamy white flower's. $10 \mathrm{cts}$, each.

Marvel. Rosy white, striped and spotted with crimson. $10 \mathrm{cts}$, each.

$\boldsymbol{M} \boldsymbol{r}$ s. C. $\boldsymbol{H}$. Wheeler. Old gold and erimson with large, broad petals. Very distinct. $15 \mathrm{cts}$. each.

Iedusu. Long, drooping. thread-like pue white petals. Very distinct and fine. $10 \mathrm{cts}$ each.

SPECIA I OFFER: For \$3.00 I will send one each of the entire list of 21 best rurieties unmed above. This is surely the best Chrysunthemum offer ever made.

The seeds of house plants I had of you gave me the greatest pleasure. I had 110 plants of Gloxinias and I think every seed of the Cineraria oame up. Caluolaria and Begenia gave the hest of satisfaction. Your seeds will all germinate if care is taken to plant them properly.-Mrs. Tevar Lewis, Cumlerland Hills, $\mathrm{I}_{\mathrm{e}}$.

I received seeds ordered of jou and was pleased when I opened the package to find how very generous you bad heen. I not only bad more seeds in quantily, hut more packets than from any other seedsman. I have planted all of the very early seeds and to my suiprise the Asters are coming up this morn. ing. The Ten Week Stock bave heen up three days and I am sstonished at the MLocn Flower. I plasted the seeds in one hox and to-day I am moving seven of them into pots by themselves. I have followed your directions as nearly as possible. I am pleased with my success thus far. Last year I spfnt quite a sum on seed that did no good at all and for several years back have had sucl poor luck that I felt "shakey" to try any more. but it. seems that in changing dealérs my luck bas changed also. Shall recomend your seeds every time.- Mrs. GEn. A. HoBART, Hingham, Mass. 


\section{NEW DWARF FRENCH CANNAS.}

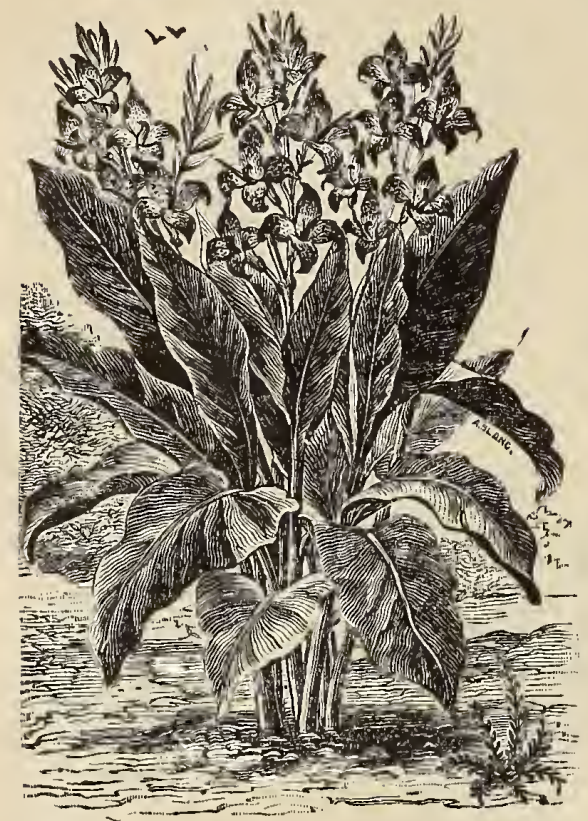

NEW FRENCH CANNA-EMILE LECLERC.

These magnificent large-flowered Crozy Cannas are destined to become exceedingly popular for bedding. They have beautiful foliage and large spikes of flowers, each flower from 3 to 5 inches across, and they are continually in bloom through the season from May to October. They grow from $21 /$ to 4 feet tall and are as easily grown as a Dahlia in any good soil. The roots ean be wintered in any warm cellar and may be started early in the house or planted out in May. The following were selected from a larg $\varphi$ number of varieties and are the very best of recent introdurtion.

$P$. Marquant. Flowers of the largest size, bright salmon scarlet, changing to rosy carmine. 75 cts, each.

Star of '91. This magnificent variety is one of the very finest yet introduced. The plant is of dwarf habit, seldom exceeding two feet in height, while it has enormous spikes of bloom, each flower abont 3 inches across. of the brightest scarlet color with a narrow golden yellow border. It begins to bloom when quite small and it makes a grand pot plant, flowering freels all winter. 20 ets. each.

Madame Crozy. This is now considered to be the most distinct and best of the new rarieties. The flowers, which are of a dazzling crimson scarlet color, each petal bordered with golden yellow, are rery large, often in inches across, and are borne on branching spikes. $40 \mathrm{cts}$. each

Alphonse Bouvier. The flowers of this are as large as those of Nadame Crozy, but of a different color, being of a brilliant crimson. It is a novelty of last season aud is one of the very finest of all. $75 \mathrm{cts}$, each.

Henri $\boldsymbol{L}$. de Vilmorin. A very distinct variety, the centre of the flower being of a brownish red shading off to a blight yellow at the outer edge 50 ets. e.sch.

The Gavien. Flowers large, intense orange scarlet of a distinct shade, $50 \mathrm{cts}$. each.

Emile Leclerc. This variety has large golden yellow flowers mottled with crimson, resembling some of the finest Orchids. $20 \mathrm{cts}$. each.

Childsi. Flowers large, yellow spotted with dark crimson. Very distinct and fine. 15 ets. each.

Noutomi. A variety of great beauty, having spikes of large flowers of the most brilliant crimson, 15 cts. each.

Robusta Perfecta. The finest of all the foliage varieties. The plants grow 7 or 8 feet tall with immense leaves 3 feet loug, of a bright bronze red color. $15 \mathrm{cts}$. each.

SPECIAL OFFER. For. 100 we will send the fonr Inst varieties listed rbove, and atso the other reny ehoiee NEW varieties not on this list and one Stur of'91.

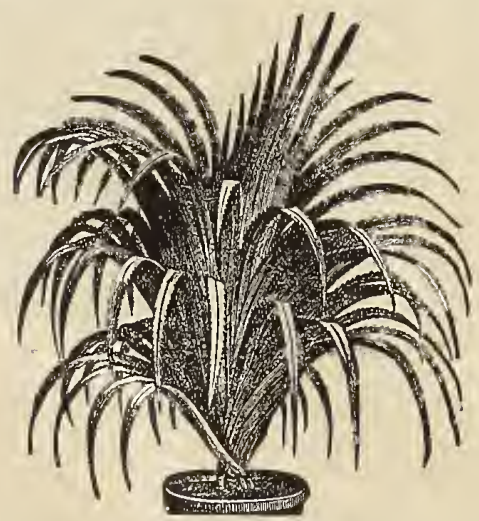

PANDANLS UTILIS.

PdNDA VUS utilis. For the decoration of halls windows or conservatories, this plant is unsur passed ; and it will stand more neglect than any other plant. Its beautiful, dark green foliage is arranged in a gracetul, spiral form. $30 \mathrm{cts}$. each.

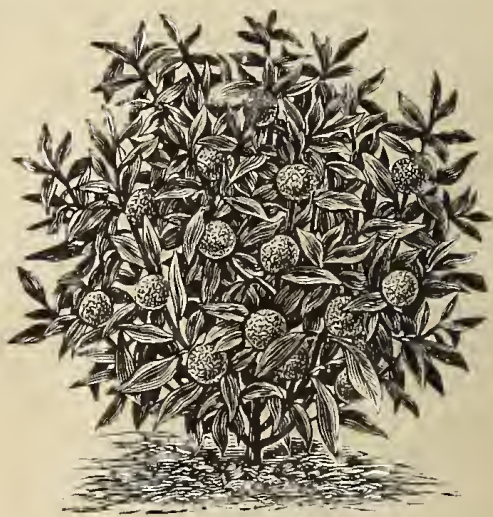

ORANGE, OTAHEITE.

DWARE ORANGE, Otreheite. This makes one of the prettiest pot plants that can be imagined, flowering and fruiting freely in pots even when only a foot tall. The fruit, although small, is sweet and good. Fine plants, $25 \mathrm{cts}$. each.

The Brazilian Morning Glory seeds received from you last year gave us some magniflcent plants which were much admired all summer.-Mrs. V. S. GuILFORD, Lansdown, Pa. 


\section{A Rare and Interesting Plant.}

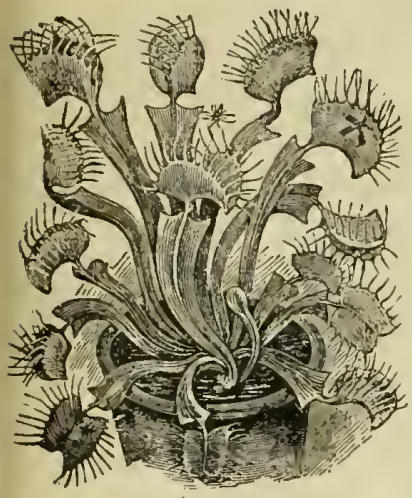

VENU'S' FLY TRAP.

THXUS FIJ TRAP (Dionea muscipula). This is one of the most remarkable and iuterestiug plants iu the world. As shown in the cut, its leaves ale furnished at the $t$ uds with a curious trap-like arrangement, the inuel surface of which is covered with sensitive bair-like organs, and wlifu a fly or auy small insect lights upou them, they close up in au instaut, aud ho"ds him a prisoner until dead, after which they open agaiu and are ready for more game. Tli trups also elose if tulched with a stick or anv light substance and it is always a source of amusement to visitors. It is very rale. being found only in one place in the world. The great naturalist. Da rwin, $f$ xperimented with this plant and tound that the inseets cainght were absorbed and furuisled nutriment for tle plant. It hears a spike of pretty, wlite thowers in the spring. It is easily r:ultivated as a window plant and thrives iu a nisture of peat, sand anc? swamp moss. Set the plant in a four iuch pot and place this in a saucer, in which water should always be kept standing. 25 cts. each, 3 for $60 \mathrm{cts}$.

CLERODENDRON Balfomi. This is one of the most lovely of all house plants. It is of slender half-clin bing habit and bearg great pendant panicles of flowers in profusion. The flowers are creamy white with a bright crimson centre and borne in profusion in winter, and all summer if bedded out. It is as easy to grow at a Fuchsia and needs about the same treatment. $25 \mathrm{cts}$. each.

\section{NEW WHITE FUCHSIA.}

Corntess of Aberdeen. This lorely new variety will be a great pavorite. It is of a pure waxy white, hoth sepals and petals, sometimes with a tiuge of flesh color where exposed to the sum. The plant is of compact, healthy growth and pro duces its flowers iu the greatest profusion. 2J cts. each : 3 for 50 cts

Trailing $Q$ ween. A beautiful new sort of gracefu trailing habit. The flowers are borne in large droopive clusters and are of a bright rosy scarlet color. It is a very profuse bloomer, a good plant showing hundreds of flowers at one time. "20 cts each : 3 for 5 i cts.

Mr.s. E. G, IIIll. This is the finest of all double white varieties. The plant is of strong vigorous growth, even with ordinary treatment, and a profuse bloonier. The flowers are of large size and very double, with a pure white corolls and dark red sepals. $15 \mathrm{rts}$. eqch : 3 for $30 \mathrm{cts}$.

SPECIAL OFFER: These 3 new Fuchsias for $10 \mathrm{cts}$.

Fuchsius in variety. 30 other choice sorts, single and double, $10 \mathrm{cts}$, each ; $\$ 1.00$ per doz.

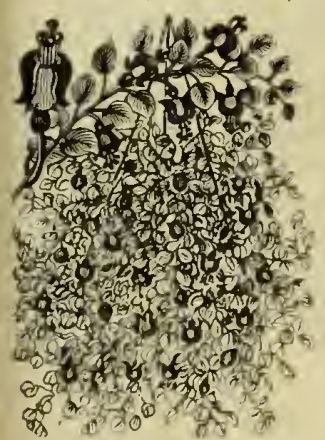

FUCHSIA PROCUMBENS.
FUCHSIA I'RO. $C U \boldsymbol{U} \boldsymbol{B} \boldsymbol{N}$ (The Trailing Fuchsta). A beau tiful plant for a hanging basket or pot. The flowers are small and free ly produced, and followed by $s e \theta d$ ressels of the form and color of cran. berries, which hang on the plant for a long time $20 \mathrm{cts}$. Caladiums, Fan cy. I have a fine assortment of these magniflcent variagated le af plants. $35 \mathrm{cts}$. each.

Heliotrome. 5 best sorts, 10 cts, each, 5 for 45 cts. FETUVI S, Houble. Of these I have a large collection of the fluest finged or lace-edged $\nabla a$ rieties. Price, $15 \mathrm{cts}$, each; set of 6 finest sorts for $55 \mathrm{cts}$.

FER BWVAS. In April and Mas I shall have

flne stock of the ver best Verbenas of all colors.

Price, 10 cts. each : 6 for 40 cts.: 12 for 75 ets.; $\$ 5.00$ per 100.

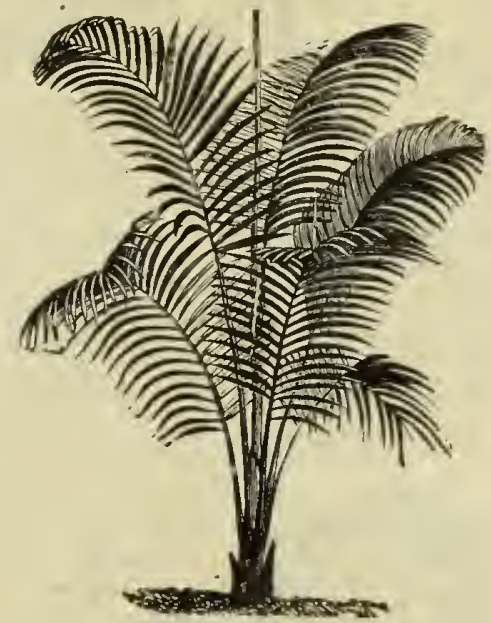

PALM-COCOS WEDDELIANA

FAIMS. These are the most common and use ful of all decorative plants. I offer the three finest varieties.

Cocos Weddeliame. This is generally consid ered to be the more elegant and graceful of al Palms. 50 cts, each.

IATANIA Borbonica (Chinese Fan Palm) This is the typical variety of Palm, with large broa leaves, and is more commonly used than any other. $30 \mathrm{cts}$. each.

Washingtonia filferr. A beautiful species having long thread like filaments drooping from the edges of the leares, Fine plants $20 \mathrm{cts}$. each ' 4 for $60 \mathrm{cts}$

SFECIAL OFFER: One each of the above Palms for $85 \mathrm{cts}$.

CENOTHERA rosm, A very pretty plant of graceful, spreading habit, introduced by me se oral years ago and extensively advertised last rear under the name of llexican Primrose. It has salver shaped flowers about $?$ inches acloss, of a charming shade of pink with a white cen tre. It is excellent for baskets or pots. Fine plants, $10 \mathrm{cts}$. each : 3 for $25 \mathrm{cts}$; 13 for $\$ 1 .(0$. 


\section{The Great Abyssinian Banana.}

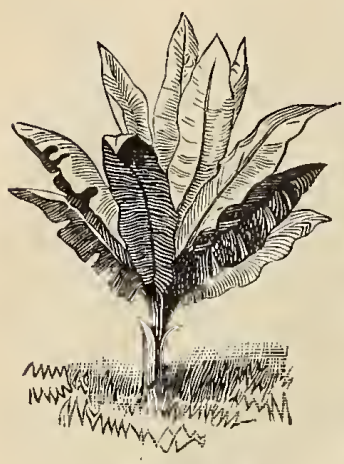

MUSA ENSETE.

\section{MUSA ENSETE.}

This is the most magnificent of all foliage plants and has the largest leaf of any plant in the world, growing 25 feet tall, witl leaves from 10 to 15 feet long and 4 or 5 wide. Small plants set out the last of May are very effective the first year. They can he taken up in the fall and easily wiutered in a nearly dormant condition in a warm cellar or green-house. The secon $x$ season, if set in very rich soil and supplied with an abundance of water through the season they grow with astonishing rapidity and are grand Price, $40 \mathrm{cts}$. each, 3 for $\$ 1.00$. Larger plants, hy express only, $\$ 1.00$ to $\$ 2.00$ each.

MONTHLT CARNATIONS. The Monthly or Pervetual Carnation on account of its beauty and fragrance should be in every collection of plants. The plants may be set in the garden during summer, keep all buds pinched off till fall, then pot up for the house and they will hloom all winter. The following are the hest and most distinct varieties. Price $10 \mathrm{cts}$. each, the 5 sorts for $45 \mathrm{cts}$. A merican Flay. striped white and scarlet; Anma Webb, crimson maroon; Gruce Wilder, pink; Golden Gate, yellow; Mr's. Fisher, white.

SANSEVERIA Zealanica. A most beautiful plant for the decoration of halls or drawing-rooms. The leaves are thick and fleshy, swordshaped, ahout 3 feet tall heautifully mottled crosswise with hands of dark green on a light ground color. $20 \mathrm{cts}$. each.

\section{New Tom Thumb Dahlias.}

An entirely new class of very dwarf Dahlias, for which we are indebted to Mr. T. W. Girdlestone, Secretary of the National Dahlia Society of England. The plants form compact little bushes only 12 to 18 inches tall hy about two feet across. The flowers are single, ahout 4 inches across, of the most brilliant colors and produced in ahundance. They will no douht hecome very popular for bedding. The following are the hest varieties: Bootles, rich velvety red; Bantam, dark scarlet; Hoop-La, rich velvety maroon; Midget, pure scarlet; Miss Grace, light orange; Tom Tit, orange scarlet. Price, growing plants only, ready May 1st, 30 cts. each ; 3 for 75 cts.: 6 for $\$ 1.25$.

DOUBLE DAHCIAS. In April and May I shall have a fine stock of the hest Double Dahlias, growing plants all ready for planting out. The following are selected from a large number of varieties as the best and most distinct. Price, $15 \mathrm{cts}$. each ; 3 for $40 \mathrm{cts}$; 6 for 75 cts.; 12 for $\$ 1.40$.

SIX BEST UARGE-FLOWRRED VARIETIES: Chris. Ridley, deep, rich maroon scarlet; Miss Browniny, sulphur yellow, mottled with white; Snowdrift, pure white; $\boldsymbol{L}$. W. Goodell, very large, rich purple flaked and spotted with crimson lake; Lucy Francett, cream spotted and flaked rose; Mrs. Gladstone, delicate soft pink.

BEST SIX LIUIPUTIAN VARIETIES: These have small very perfect flowers and are the hest of all for cutting. Ada, yellow, variegated with pink; Little snowbrill, pure white; Butter$\boldsymbol{f l y}$, orange tipped scarlet; $\mathbf{T m}$. $\boldsymbol{L}$. Marshal, yellow tipped with red, very perfect form; Persuit, deep maroon; Little Herman, crimson, variegated with white.

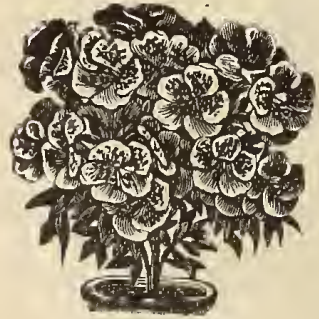

CHINESE AZALEA.

\begin{abstract}
$A Z A L E A$ INDI$C A$ (Chinese Azalea). A beauriful plant for wind ow or conservatory decoration, bearing a mass of gorgeous flowers in winter or s p r in g, heginniug when plants are quit e small and increasing in bea ty each year. I have a fine assortment of varieties; wh it e, rose, crimson, striped, etc. Price, 40
\end{abstract} cts. each ; set of 4 hest varieties, for $\$ 1.35$.

PLEROMI macranthum. This is a most beautiful. old, but little known plant. It is of easy culture and hears flowers very frcely. These are 3 to 5 inches across and of the richest deep violet purple color, a shade very rare in flowers. The plants begin to hloom when very small and may he grown in hush form in a pot in any win. dow, or trained on a rafter in a greenhouse, and there is no hetter plant for this purpose. $25 \mathrm{cts}$. each.

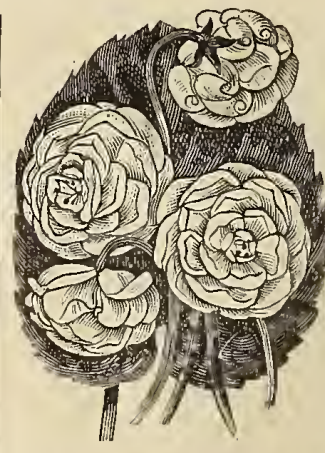

Double Violets. The double sweet violet is easily cultivated, but is not hardy. Plants should be set in the garden in summer, taken up in Septemher, and potted for the house, where they will hloom all winter, if kept in a cool,sunny window. Swanley White. Large, pure white. $10 \mathrm{cts}$, each.

Marie Louise. Rich violet hlue. 10 cts. each.

VIOLET-SWANLEY WHITE.

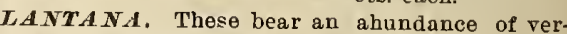
hena-like flowers on shrubby plants. All colors, orange, crimson, yellow, rose, white 10 cts. each ; 4 for 35 cts.

I was very much pleased with the Primula obcomia, and all who see them admire them very much your seeds never fail to come up.-Nellie E. Crark, Cromwall, Conn.

The box of plants came to-day and were all in fine order, and they were packed so that they were heautiful in their packing.-S. B. CHASE, Linden, N. J. 


\section{Achillea Ptarmica, fl. pl., The Pearl.}

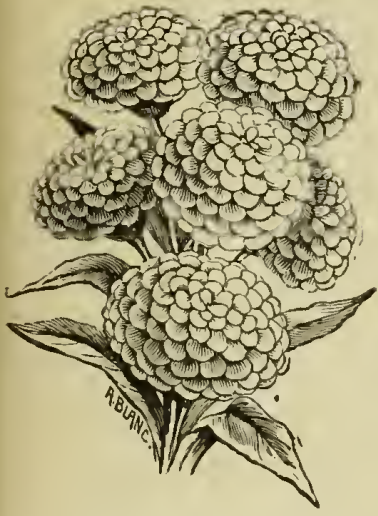

ACHILLEA-THE PEARL.

This is one of the most useful and valuahle plants in the entire list. It is perfectly hardy and will thrive anvwhere and in anv soil or situation, with little or uo care, blooming profusely for many years. The tops die down in the fall, the roots throwing up numerous stems in the spring to the height of a foot or more each stem crowned with a large panicle of 50 or more small, double flowers of the purest white. It continues in bloom from July to frost, bearing hundreds of flowers the first year, while old plants will bear thousands each season. It is one of the finest things I know of for houquets, and for planting in cemeteries it has no equal. This new sort is much superior to the old $A$ albre $l_{*}-p l$, the flowers being larger, more double and pure white. Price, 15 cts. Pach ; 3 for $30 \mathrm{cts}$. : 6 for $50 \mathrm{cts}$; 13 for $\$ 1.00$.

GENISTA, tinctoria fl. $-\mathrm{pl}$. (Mound of Gold). This is also one of the choicest and hest of hardy perennials. The plant is of compact spleading hahit, not over a foot in height, and is completely covered in.June and July with small golden sellow douhle flowers. 15 cts. each; 3 for 35 cts. ; 6 for tio cts.

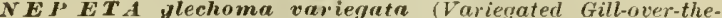
ground). An elegant trailing pla.dt with pretty foliage, which is edged and blotched with white. Nothing can he finer for hanging haskets or pots, trailing down over the sides in a most graceful manner. $10 \mathrm{cts}$ each ; 3 for 25 cts.

INPOMOEA prendurata (New Hardy Tuberous-rooted Moonfouer). This grand climher is perfectly hardy, a single vine when established will cover a large space. The flowers are 3 or 4 inches across, pure white shading to pink and purple in the centre, and

are borne freely for several months. Fine tubers, 25 cts, each, 5 for $\$ 1.00$.

\section{DWARF EVERBLOOMING CALLA.}

The great value of this elegant Calla over the old sort consists in its dwarf hahit and abundance of hloom. It takes up hut little room and the flowers not heing more than oue-half the size of the common variety, are much hetter for bouquets, and it will produce twice as many flowers during a year. It is almost alwavs in hloom and every way superior as a pot plant to the common variety. Fine plants, 40 ets. each, 2 for 75 cts.

BLACK CALLA (Arum Sanctum). A most stately and elegant plant, with rich dark purple flow ers from 14 to 18 inches long and four inches wide. It is a native of Syria. $50 \mathrm{cts}$. each.

SPOTTED-LEAF CALLA (Pichardia alba maculata). The dark groen leaves of this variety are thickly spotted witl white and it is a beautiful plant even when not in flower. The flowers are similar to the common Calla, hut have a hlack centre. Besldes heing a splendid pot plant, it makes a fine hedding plant for summer. 20 cts. each.

SPECIAL OFFER: For \$1.0 we will send one each of the above 3 Calles.

FELLOW CALLA (Richardia hastata). This is similar in all respects to the common variety, ex cepting that the flowers are of a light yellow color. \$1.00 each.

ABUTILON (Chinese Bell Flower or Flowering Maple). A popular class of flowering shruhs, almost always in bloom. The following $n c w$ and improved varieties are the best :

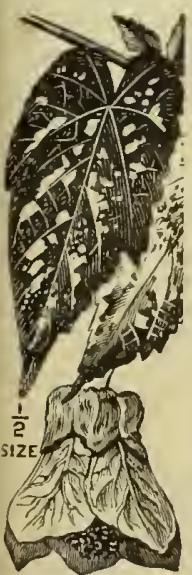

Eclipse or Leopurd. Th is elegant new variety is one of the prettiest of all variegated leaf plants, elther for pot cultire or hedding out in summer. The leaves arc spotted with golden yellow on a light green ground. Flowers orange yell ow $10 \mathrm{cts}$, each.

suow storm. White, $10 \mathrm{cts}$. koynal Scurlet. 10 cts. earth. Golden Bells. Yellow, $10 \mathrm{cts}$. CALADIUA eseulentum. A well known plant with large, thick leaves, 2 to 4 feet long. start tubers parly in the housa. First size tuhers $30 \mathrm{cts}$, each. 4 for $\$ 1.00$. Second size, 20 cts, each, 6 for $\$ 1.00$.

BEGONIA rex. These are prown for their variegated foliage. 6 best varieties. 30 (ts, each, the six for $\$ 1.50$.

II $Y \boldsymbol{D} A \boldsymbol{N} \boldsymbol{E} A$, Red Bronched. A grand new sort of the popular green-house Hydrangea, with enormous pauicles of pink flowers. 20 ets. each.

ABUTILON,

E.CLIPSE.

PELARGONIUMS. These, popularly known as "Lady Washington Geraniums," are thollght hy many to be the handsomest of all known plants. Four best varieties $\$ 5 \mathrm{cts}$. each.

\section{TWO CHOICE GERANIUNS.}

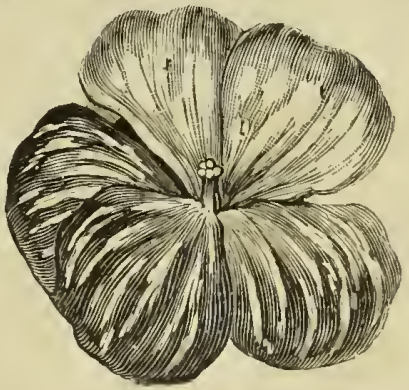

Souvenir le Wirume. (The Peach Blossurn (rerunimm). The most distinet and beautiful new Gerauium that has heen introduced for mally vears. It is iu fact the first of an entilely new type of coloring. The upper petals are ereamy white with a distinct rosy pink border: lower petals, rosy salmon shaded and streaked with white. It is very free-flowering, hearing large trusses of its lovely blooms. No description can do it justice; it must be seen to he appreciuted. 15 cts. each. 3 for 10 cts. La favorite. The fiuest of all double white $\mathrm{va-}$ rieties, which should he in all collections. It is a remarkahly free hloomer, a well grown plant heing a perfect hall of flowers. $15 \mathrm{cts}$. each. noth of the above for $25 \mathrm{cts}$.

Geruluism, iu variety. 50 hest new and old varieties, double and single, $10 \mathrm{cts}$. each, $\$ 1.00$ per doz. 


\section{New Hardy Double Russian Violet.}

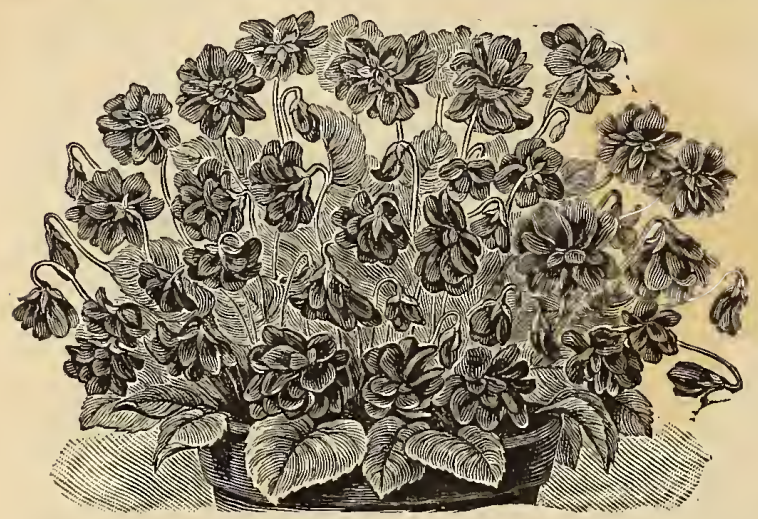

HARDY RUSSIAN VIOLET,

It is safe to say that uo flowering plant ever introduced is more valuable than this. It is a perfectly hardy varietr, which will grow and bloom in any garden and in any situation. It is perfectly healthy and free from disea $=e$. very frayrant, and as hardy as a Pansy. It is a strong, vigorous grower, small plants set in good soil iu spring forming clumps 8 to 12 inches across by fall. It is strictly a garden plaut and does not succeed as a house plant. Its flowers are very large. deliciously fragrant. a dark rich violet-blue. and are produced in abundance from April to June. Some idea of its wouderful bloomiug qualities and value may be gained from the fact that the originator cut 34,000 flowers trom a bed 4 feet wide and 150 feet long, which sold for over $\$ 200$ at wholesale. I have placed the price.very low this season to induce all my customers to plant at least a small bed of it. Price, 15 ets. each; 3 for 85 cts.; 9 for $\$ 1.00 ; 25$ for $\$ 2.50 ; 50$ for $\$ 4.75 ; 100$ for $\$ 9.00$.

IRIS Kampferi (Japanese Iris). This magnifcent species of Iris produces the most gorgeous flowers known, equal to the tuest Orchids. 'They grow 3 to 4 feet tall and bear both single aud double flowers, many of which are 8 to 10 inches across and of various ricl colors and markings. They will grow and tlower well in any soil, but do best in a rich, heavy moist loam, with plenty of water. 12 finest named varieties, 25 cts. each ; 6 for $\$ 1.00$. Mixed varieties, all colol's, $10 \mathrm{cts}$. each; 12 for $\$ 1.00$.

IRIS Germmica (German Iris.) These are perfectly hardy and will grow in any soil or situ ation with lictle or no care. The flowers are smaller than those of the Japan Iris, but they are of all colors most elegantly spotted, reticulated and variegated on rich jellow. brown and purple grounds. Nothing i t the toral world su'. passes them in beauty except the tropical Oruh ids. 12 best named sorts, 15 cte. each, 4 for 50 ets., 12 for \$1.25. The same, without names, 10 ers. each ; 4 for 35 cts. : 8 for 75 cts.; 12 for $\$ 1.00$.

CHINES E PAONIES. I have a large collection of these magnificent plants, consisting of all colors-white, rose, crimson, pink variegated, etc. 35 cts. each

PANSY PLANTS. I can supply Pansy plants of the Dianiond straiu, all varieties inixed, in April. Price, seed-bed plants, which will begin to bloom in May, 30 cts. per doz.: 50 for $\$ 1.00 ; 100$ for $\$ 1.75$, my mail, post-paid. These can be supplied in April ouly. Not less than oue dozen sold.

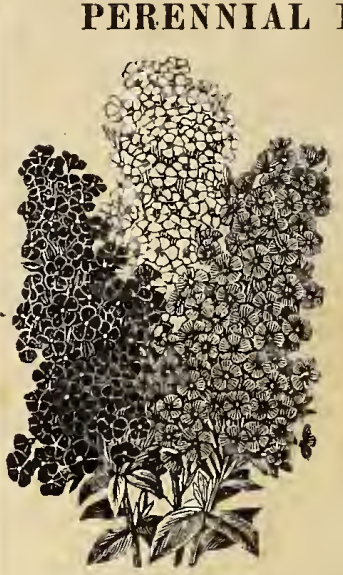

PERENNIAL PHLOX.

\section{PHLOX.}

The Perennial Phlox is the best and most showy of all hardy bel. baceous plants. Those who have seen nothing but the old purple and white varieties can have but a poor idea of the great beauty of the new aud im proved sorts. We now have them with flowers as large as a silver half dollar and of every shade from pink to the most brilliant crimson, most of them with $\operatorname{large} \mathrm{d}$ istinct centres of another color; and they bea $\mathrm{r}$ enormous panicles of bloom from July to October. I offer six of the best and most distinct sorts. Pri e, $15 \mathrm{cts}$. each; 6 for $80 \mathrm{cts}$.

\section{SEEDS FOR THE WILD GARDEN.}

What is called a WILD GARDEN is becoming very popular. The plan is to take some back corner or spot in the gardeu and sow a quantity of the most hardy flower seeds that have been well mixed together, and, except to keep down the weeds, allow them to pretty much take care of themselves. The effect is very striking. I had many calls for such seeds last year, and have put up packages expressly for this purpose. Price per large package containing over 100 varieties of seeds best adapted for the "Wild Garden," well mixed, 25 cents.

एᄌㅓㅇ No order for Plants filled for a less amount than $\mathbf{5 0}$ cents, unless 10 cents extra is added for postage and packing. (See page 28.)

My plants from your seeds last year, were a great success. The Brazilian Morning Glory covered the tall bare truuk of a pine tree and made it a thing of beauty. The Gladioli, Double Portulaca. Everlasting and other thiugs flourished equally well. Every one of the Brazilian Morning Glory thd Euphorbia Hetersphylla, germinated aud grew wouderfully. I thought your collection last year exceeded an 5 thing ever put for a collection of flower seeds.-Ltcretia D. Pvrsas, Forestdale, Mass. 


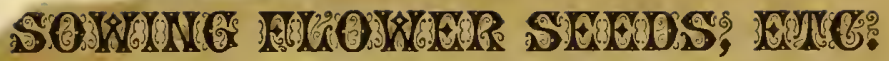

JWING IN CoLD-FraMES. - A cold-frame is easlly managed by anybody, and in no other way can such aiform succoss be had; and I would recommend those who have more than half a dozen varieties to sow to try one. Make a box-like frame of boards without a bottom, which should be $t$ welve or iffeen inches high at the back, sloping to about six inches in front, so as to catch the direct rays of the sun as much as possible. It can be made of any size desired and nailed at the corners, if small enough te be easily moved about, or if larger, fastened together with hooks and staples. About the :5th o: April is the proper time in this latitude to start seeds in a cold-frame, and the plants will be large enough to transplant to the beds where they are to bloom as early as would be safe from frost.

Prepare a bed in a warm sheltered spot in the garden; rake out all the lumps and stones and on this set the erame, and cover with ordinaly hot-bed sash or old window sash which will do quite as well. Make the soil in the frame smooth and firm with a board, and sow the seeds thinly and evenly on the surface in squares, and label each sort with a short pine label. Have a pile of light sandy goil or leaf mold ffom the woods, which has been sifted through a finesieve, near at hand, and if the se日ds are very small, carefully sift it over them. Probably more failures to make seed germinateresult from covering too deep than from any other cause. A good and safe rule for the smaller kinds of seeds is to cover to a depth of about twice the diameter of the seed. This would give a covering of one-eighth to one-fourth of an inch to such seeds as Aster, Phlox and Verbena: one-sixteenth of an inch to Petunia, Portulaca, and seeds of like size, while very fine seeds, like Lobelia and Mimulus, should only be covered a little, just enourh to oover the seeds from sight. After the seeds are all nicely covered, it is very important to make the soil as hard and firm as possible; then water carefully with a pot having a fine rose, so as not to wash the soil from the seeds.

Now put on the sash and lreep it tightly closed until the plants begin to come up, watering often enough to keep the surface moist. Some seeds, like Aster and Zinnia, germinate, under favorable circumstances, in a few days, while others require several weeks. Geranium and Verbena seeds germinate very unevenly, some seeds coming up in a week or ten days. while some remain dormant a month or more, and the soil should be kept moist and not be disturbed for at least a month after sowing. Cover the frame with straw mats or boards at night to keep out the cold, and after the plants are up give plenty of ail, during warm, sunny days. Pull out the weeds as fast as they appear. and keep the plants well thinned out, so they will grow strong and stocky. The thinnings cau be saved and trans. planted to auother frame if desired.

SowING IN Boxes iN THE HoUsE.- When only a few varieties are to be sown, good plants can be grown by sowing in shallow boxes of earth, putting these in a warm, sunny window in the house, coveriug each box with a pane of glass to retain moisture. Never sow seeds in pots unless they are sunk up to the rims in boxes of moist earth or woss; otherwise they are apt to quickly dry out and injure the seeds or young plants.

SowING IN THE OPEN GROUND.-With care and by sowing at the proper time, plants can be grown successfully in the open ground; but not much success can be expected from sowing the small, delicate soeds in the beds where they are to flower. It is always best to sow all but a few varieties like the Larkspurs aud Poppies, which do not transplant well, in a seed-bed, in the same way as directed for cold-frames. Sow the half-hardy varieties about the first of May, in this latitude, ior about the time corn is usually plantod. Hardy annuals may oe sown two weeks earlier. and tender annuals not until two weeks later than this. Great care must be taken in watering and shading to prevent the surface from drying out: a few hours of hot sun in a dry time will sometimes ruin a whole bed: and this is the most frequent cause of failure when seeds are sown in the open ground, for after a seed has sprouted, and then becomes dry, it will never sprout again. It is a good plan to sp. sad several thicknesses of newspaper over the bed to help keep in the moisture, but they must be removed as soon as the plants bozin to $\operatorname{come}$ up.

TRANSPLANTING.-After the plants in the cold-frame or seed-bed have obtained their second leaves and grow'a an inch or $t$ wo, transplant to the garden, flrst giving the seed-bed a good soaking with water. Transplantang should be done in a showery day, if possible, but it is better to transplant in a dry time than to wait too long for rain. Make holes where the plants are to be set, fill them with water, let it soak in, then set the plant, making the soil firm about the roots; water again and corer each plant with a piece of paper held down with clods of earth; or, what is better, with a large leaf or a bandful of fresh grass, which is to be removed after a few days.

A frequent cause of failure to make a good show of flowers is setting plants too thick in the beds, and before the summer is half through the vines become so crowded together they either die outright or become so much weakened in the struggle for existence, that their beauty is greatly injured. The soil for flowers, if not already rich, should be made sc with fertilizers or well decayed manure. Some varie. ties do well in almost any ordinary soil, but do much better in a rich oue.

The flowers ploduced from seeds are classed as Annuals, Biennisls, and Herbaceous Perennials. The Annuals perfect their seed and die the first year. Biennials live two years. Herbaceous Perennials die down to the ground every year, their roots living many years. Annuals arecalled hardy, half hardy and tender. A hardy annual will bear a severe frost without injury; a half-hardy annual will bear considerable frost; while tender annuals are destroyed by the least frost.

\section{FOOD FOR FLOWERS.}

This is a fertilizer made expressly for flowers grown in the house or garden, and is the best thing of the kind I have ever tried. It is free from odor and clean to handle. It produces a healthy, lusuriant growth, which is soon followed by au abundance of flowers. Everybody who has ever tried it has been delighted with the results. It is used by dissolving a little in water and applying to the soil once a week. Trial packages 25 cents each, postage paid. Large packages by mail, post-paid, 50 cents each. Directions for use and a valuable little pamphlet on the culture of house plants free with each package

"The use of the Food for Flowers has given the most satisfactory results, rendering my plants strong and healthy, and kreping them in constant and vigorous bloom for months without any seeming exhaustion of their strength.

Mrs. A. B. M., Burton, Vt.

"The package of Plant Food was more than sntisfactory. It caused my plants to grow, bud and blossom.beyond all my expectations. Have kept quite a variety of plants for twelve years, but never were they half so satisfactory as after using your Food."

Mrs. H. W. P., Andover, Me.

\section{A SPECIAL REQUEST.}

I publish my Catalog annually in January, and mail a copy to all who ordered seeds the provious year, without their asking for it. I hope that each one will find something among the many good things offered that they want, and send at least a small order, if only a ten cent one, so that their names will-appear on my books for a Catalog next year. If you only want a few seeds, do not hesitate to order them because the order is small, for I always fill small orders just as carefully and cheerfully as large on 8 , although of course the larger the better. But should you not desire anything yourseli this year, please do me the great favor to hand this Catalog to somefiiend who is in the habit of order. ing seeds awuy from home, and if you will, at tho same time, say a good word for my seeds, I shall be aubly obliged; and if you dosire a Cataloe next year please let me know and I shall be glad to keep name on my books. 


\section{The Mpxiean Grep Mогрing Glo. x. \\ IPOMGA GOODELLI.}

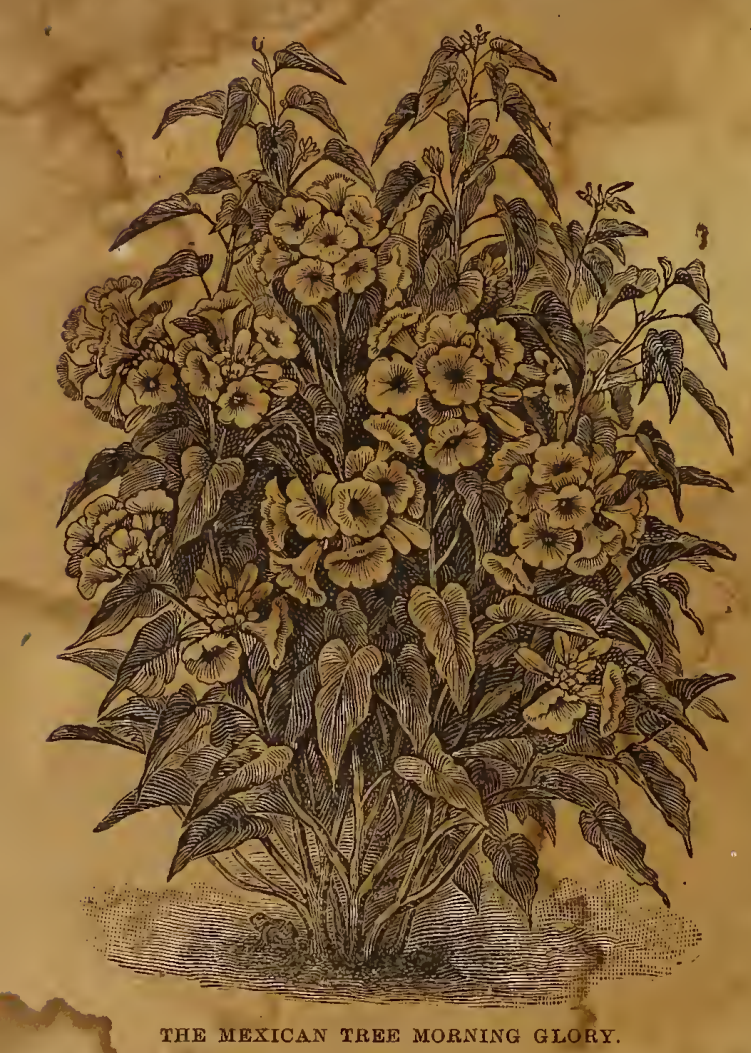

A Genuine Novelty. This is not onls absolutely new but it is so entirely different from anythiug else and such a showy plant that it is sure to attract the attention and admiratlon of everyone wherever grown. It is a native of that wonderful country, Mexico, and is a shrubdike herbaceous perennial. The cut, which was engraved from a photograph, gives a correct idea of a plant in flower. In a rich moist soil it attains a height of 6 or 7 feet. It flowers the first season, the plant inoreasing in size aud beauty for several years. The flowers, which are of a ligbt rose color with a crimson centre and 3 to 4 inches across, are borue in large panicles or clusters of 25 to 50 in the axils of the leaves, a cluster to nearly every leaf. These clusters are from 6 to 10 inches in diameter and on stems 6 inohes long, from 3 to 8 flowers openiug ì each cluster every morning from June to frost. It is porfectly hardy in the southern gulf states and will probably stand the winters as far north as Washington, D. C. With a protection of leaves or straw over the ruots. In the Northerm States it can he grown as a tub plant like an Oleauder. moving it to the house or cellar in winter; or it cau be planted out in the summer, the roots taken up iu the fall and preserved in boxes of moist earth in a warm cellar over winter. In any case the tops should be cut back nearly to the ground as soon as frost has killed the leaves. I have the entire stock of this graud species and offer fine plants for $30 \mathrm{cts}$. each, or 4 for $\$ 1.00$. Seeds $30 \mathrm{cts}$. per packet.

\section{SHADY HILL NURSERIES.}

CAMBRIDGE MASS.

OVER 200 ACRES.

A WORD OF ADFICE? If sou contemplate planting in the Spring of 1892 any kiud of Nursery Stock, do not overlook the above address, but send there for any of the more

\section{RARE AND BEAUTIFUL TREES, SHRHBS, ROSES, HARDY PLANTS, Uc.}

YOU WULL GET WHAT YOU ORDER TRUE TO NAME, IN THE VERY BEST CONDITIV, and at reagonable prices. Besides growing the most unique collections of Opamental Stock in the United States, the

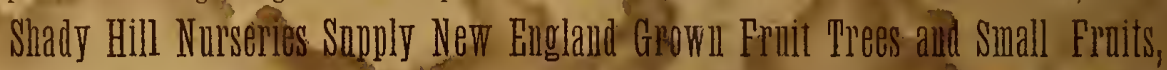
In all varieties, WELL ROOTED and superior to the average stock sent out. A special feature is the remarkable collection of

HARDY HERBACEOUS PERENNIALS.

We send to any address on receipt of two stamps both of our large Illestrated Cataloguhs. Also send for special Cuub TERMS which are very advantageous to those who wish to get up Club orders for our Stock.

SHADY HILL NURSERY CO.

EF I am well acquainted with the proprietors of Shady Hill Nurseries, who are eut ising and thorough business men, and I recommend those who desire anything in their line to p\& s the tur. feeling conflent that all who do so will be supplied with flrst class stock. SHADY HiLl $\mathrm{N}$.rinies are Headquarters for everything that is New, Rare and Choice in the way of Ornamental Treds Shrubs Hardy Plants.

above. Send all orders for Nursery Catalogs or Stock to the address given in the adver
L. W. GOC 